UNIVERSIDADE DE SÃO PAULO

FACULDADE DE ECONOMIA, ADMINISTRAÇÃO E CONTABILIDADE DE RIBEIRÃO PRETO

DEPARTAMENTO DE ADMINISTRAÇÃO

PROGRAMA DE PÓS-GRADUAÇÃO EM ADMINISTRAÇÃO DE ORGANIZAÇÕES

OTÁVIA TRAVENÇOLO MUNIZ SALA

Conhecimento em sustentabilidade no curso de Administração nas escolas de negócios brasileiras signatárias e não signatárias do Principles for Responsible Management Education (PRME)

ORIENTADORA: PROFA. DRA. ADRIANA CRISTINA FERREIRA CALDANA

RIBEIRÃO PRETO 
Prof. Dr. Vahan Agopyan

Reitor da Universidade de São Paulo

Prof. Dr. André Lucirton Costa

Diretor da Faculdade de Economia, Administração e Contabilidade de Ribeirão Preto

Prof. Dr. Jorge Henrique Caldeira de Oliveira

Chefe do Departamento de Administração

Prof. Dr. João Luiz Passador

Coordenador do Programa de Pós-Graduação em Administração de Organizações 
Conhecimento em sustentabilidade no curso de Administração nas escolas de negócios brasileiras signatárias e não signatárias do Principles for Responsible Management Education (PRME)

\section{Versão Corrigida.}

(A original encontra-se disponível na FEA-RP/USP)

Tese apresentada ao Programa de Pós-Graduação em Administração de Organizações da Faculdade de Economia, Administração e Contabilidade de Ribeirão Preto da Universidade de São Paulo, para obtenção do título de Doutor em Ciências.

ORIENTADORA: PROFA. DRA. ADRIANA CRISTINA FERREIRA

CALDANA

RIBEIRÃO PRETO 
Autorizo a reprodução e divulgação total ou parcial deste trabalho, por qualquer meio convencional ou eletrônico, para fins de estudo e pesquisa, desde que citada a fonte.

Catalogação da publicação

Faculdade de Economia, Administração e Contabilidade de Ribeirão Preto, Universidade de São Paulo

FICHA CATALOGRÁFICA

Sala, Otávia Travençolo Muniz

Conhecimento em sustentabilidade no curso de Administração nas escolas de negócios brasileiras signatárias e não signatárias do Principles for Responsible Management Education (PRME). Ribeirão Preto, 2019. 124p.

Tese de doutorado, apresentada à Faculdade de Economia, Administração e Contabilidade de Ribeirão Preto/USP. Área de concentração: educação para a sustentabilidade. Orientador: Adriana Cristina Ferreira Caldana

1. PRME. 2. Identidade sustentável. 3. Escolas de negócio. 4. Educação para o desenvolvimento sustentável. 5. AISHE. 
Dedico essa tese ao meu grande incentivador, meu amado pai, José Norberto Muniz.

Obrigada por ser minha fonte de inspiração! 


\section{AGRADECIMENTOS}

A minha mãe, Vera Lúcia Travençolo Muniz, que com seu amor e doçura fez com que essa jornada fosse mais leve!

Ao meu marido, Luís Fernando Sala, pela paciência, cumplicidade e companheirismo nos momentos mais difíceis!

A minha irmã e ao meu cunhado, Rafaela Travençolo Muniz e Denys Corazza Sef, por todo carinho e apoio, principalmente a cada ida minha à São Paulo!

A minha amada filha, Maria Alice Travençolo Muniz Sala, tão jovem, mas tão compreensiva! Você é minha vida, minha luz!

A minha orientadora, Adriana Cristina Ferreira Caldana, que me deu a oportunidade de compartilhar sua sabedoria, imprescindível para a realização desse trabalho.

Aos entrevistados e participantes, pela disposição em colaborar com a tese e por todo conhecimento compartilhado.

Aos membros da banca, pelas sugestões, disposição, sabedoria e contribuições para esse trabalho.

A todos os funcionários da Faculdade de Economia, Administração e Contabilidade da USP, campus Ribeirão Preto.

A Universidade de São Paulo e Faculdade de Economia, Administração e Contabilidade de Ribeirão Preto. 


\section{RESUMO}

SALA, O. T. M. Conhecimento em sustentabilidade no curso de Administração nas escolas de negócios brasileiras signatárias e não signatárias do Principles for Responsible Management Education (PRME). 2019. 124f. Tese (Doutorado em Administração de Organizações). Faculdade de Economia, Administração e Contabilidade de Ribeirão Preto, Universidade de São Paulo, Ribeirão Preto, 2019.

Esta pesquisa investiga o conhecimento em sustentabilidade nas escolas de negócios. Constam de seu conteúdo a revisão conceitual, visando delimitar o modelo PRME como quadro de referência e a sua operacionalização pelos critérios e estágios de identidade sustentável da escola, e a referência empírica, está constituída de duas escolas signatárias do PRME e de duas escolas não signatárias, permitindo identificar a relevância do PRME para as escolas signatárias. A unidade de análise foi o curso de Administração. O questionário AISHE foi o instrumento de pesquisa aplicado aos docentes e formandos do curso. O AISHE foi enviado, por email, a um total de 113 docentes, considerando as escolas signatárias e não signatárias e desses, $44 \%$ retornaram. Em relação aos discentes, de um total de 114, a taxa de retorno foi de $64 \%$, também considerando as escolas signatárias e não signatárias. A análise de conteúdo foi realizada pelo software Iramuteq para analisar fragmentos dos Projetos Políticos Pedagógicos dos Cursos. Portanto, técnicas de análises qualitativas e quantitativas foram empregadas, assim como análise de conteúdo, indicador de identidade da escola e classificação hierárquica descendente (CHD), e os dados foram representados por gráficos, tabelas, quadros e diagramas. Os resultados indicam que não há diferenças entre as escolas signatárias e não signatárias, no que diz respeito à incorporação do modelo PRME e os critérios de identidade sustentável. Há a sugestão de rever o PRME como modelo integrado de princípios, de integrar os PPCs a este modelo, de operacionalizar o modelo PRME pelo conceito de identidade sustentável da escola, a partir do qual, indicadores de gestão educacional são identificados para monitorar as fases de apreensão, implementação e incorporação do modelo PRME. Para tanto, há, também, a sugestão de criar a rede de identidade sustentável das escolas, identificando, atores, responsabilidades, funções integradas, elos e orçamentos, se constituindo em uma das etapas para alcançar os objetivos do desenvolvimento sustentável.

Palavras-chave: PRME. Identidade sustentável. Escolas de negócio. Educação para o desenvolvimento sustentável. AISHE. 


\begin{abstract}
SALA, O. T. M. Knowledge in sustainability in the f Administration courses in Brazilian business schools that are signatories and non-signatories of the Principles for Responsible Management Education. 2019. 124f. Tese (Doutorado em Administração de Organizações). Faculdade de Economia, Administração e Contabilidade de Ribeirão Preto, Universidade de São Paulo, Ribeirão Preto, 2019.

This research investigates the sustainability knowledge in business schools. There is a conceptual review aimed at delimiting the PRME model as a reference framework and its operationalization by the criteria and stages of the school's sustainable identity. The empirical reference is made up of two signatory schools of the PRME and two non-signatory schools, making it possible to identify the relevance of the PRME to the signatory schoolsThe unit of analysis was the Business Administration course. The AISHE questionnaire was the research instrument applied to the teachers and trainees of the course. AISHE was sent by email to a total of 113 teachers, considering the signatory and non-signatory schools and $44 \%$ of these returned. Regarding the students, out of 114 , the return rate was $64 \%$, also considering the signatory and non-signatory schools. Content analysis was performed by Iramuteq software to analyze fragments of the Pedagogical Political Projects of the Courses. Therefore, qualitative and quantitative analysis techniques were employed, as well as content analysis, indicator of school identityand descending hierarchical classification (CHD) and the data represented by graphs, tables, and diagrams. The results indicate that there are no differences between the signatory and non-signatory schools on the incorporation of the PRME model and the sustainable identity criteria. The suggestion is to review PRME as an integrated model of principles, integrating the PPCs into this model, in addition to operationalize the PRME model by the concept of sustainable school identity, from which the educational management indicators are identified to monitor the phases of apprehension, implementation and incorporation of the PRME model. In order to do so, there is also the suggestion to create the network of sustainable identity of schools, identifying actors, responsibilities, integrated functions, links and budgets, being one of the steps to achieve the sustainable development goals.
\end{abstract}

Key words: PRME. Sustainable identity. Business school. Education for sustainable development. AISHE. 


\section{LISTA DE ILUSTRAÇÕES}

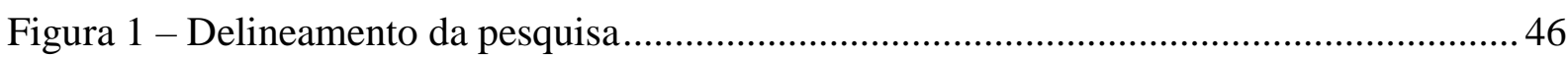

Figura 2 - Pressupostos metodológicos da pesquisa ...................................................... 53

Figura 3 - Nuvem de palavras - Escola PRME-Pública................................................ 66

Figura 4 - Nuvem de palavras - Escola PRME-Privada .................................................... 75

Figura 5 - Nuvem de palavras - Escola Não PRME-Pública ............................................... 83

Figura 6 - Nuvem de palavras - Escola Não PRME-Privada............................................... 89 


\section{LISTA DE GRÁFICOS}

Gráfico 1 - Identidade sustentável da Escola PRME-Pública para os docentes 57

Gráfico 2 - Identidade sustentável da Escola PRME-Pública para os discentes. 60

Gráfico 3 - Comportamento da ocorrência das palavras - Escola PRME-Pública. .65

Gráfico 4 - Identidade sustentável da Escola PRME-Privada para os docentes 68

Gráfico 5 -Identidade sustentável da Escola PRME-Privada para os discentes 69

Gráfico 6 - Comportamento da ocorrência das palavras - Escola PRME-Privada. .74

Gráfico 7 - Identidade sustentável da Escola Não PRME-Pública para os docentes. .76

Gráfico 8 - Identidade sustentável da Escola Não PRME-Pública para os discentes .. 78

Gráfico 9 - Comportamento da ocorrência das palavras - Escola Não PRME-Pública. .82

Gráfico 10 - Identidade sustentável da Escola Não PRME-Privada para os docentes 84

Gráfico 11 - Identidade sustentável da Escola Não PRME-Privada para os discentes 85

Gráfico 12 - Comportamento da ocorrência das palavras - Escola Não PRME-Privada.........88

Gráfico 13 - Comparação Docentes - Escolas Signatárias. .95

Gráfico 14 - Comparação Discentes - Escolas Signatárias. .97

Gráfico 15 - Comparação Docentes - Escolas Não Signatárias. .98

Gráfico 16 - Comparação Discentes - Escolas Não Signatárias

Gráfico 17 - Dendograma representativo dos segmentos de textos dos PPCs. 102 


\section{LISTA DE QUADROS}

Quadro 1 - Síntese das definições discutidas - Educação para o Desenvolvimento

Sustentável. .25

Quadro 2 - Síntese das definições discutidas - Formação Docente... 28

Quadro 3 - Síntese das definições discutidas - Liderança Responsável. 32

Quadro 4 - Síntese das definições discutidas - As Escolas de Negócio da Formação de Líderes. .36

Quadro 5 - Síntese das definições discutidas - Iniciativa PRME 40

Quadro 6 - Síntese das definições discutidas - Identidade Sustentável................................. 42

Quadro 7 - Matriz amarração entre PRME e módulo identidade AISEH...............................43

Quadro 8 - Relações das Instituições, por Estados, Signatárias do PRME Brasil.................... 46

Quadro 9 - Classificação das Escolas selecionadas..........................................................47

Quadro 10 - Módulos Conceituais do AISHE 2.0...........................................................52

Quadro 11 - Aspectos metodológicos da pesquisa..........................................................54

Quadro 12 - PPC da Escola PRME-Pública: Segmentos e descrição....................................63

Quadro 13 - PPC da Escola PRME-Privada: Segmentos e descrição....................................70

Quadro 14 - PPC da Escola Não PRME-Pública: Segmentos e descrição..............................80

Quadro 15 - PPC da Escola Não PRME-Privada: Segmentos e descrição..............................87

Quadro 16 - Síntese das conclusões por escolas, docentes e discentes................................113 


\section{LISTA DE TABELAS}

Tabela 1 - Questionários aplicados ao público alvo e taxas de retorno.................................49

Tabela 2 - Identidade sustentável, em porcentagem, para os docentes e discentes das

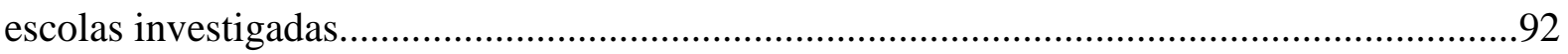

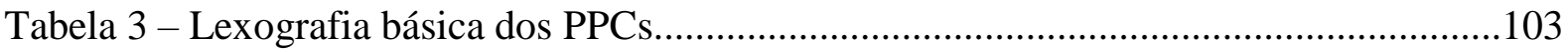




\section{SUMÁRIO}

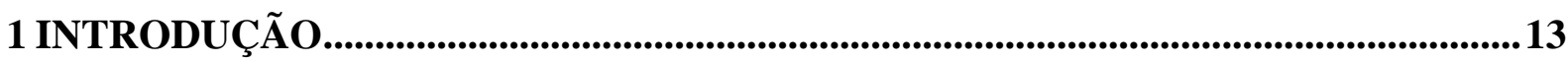

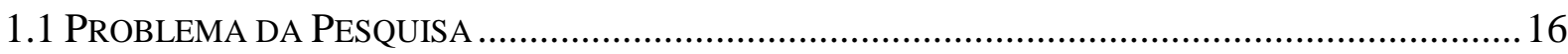

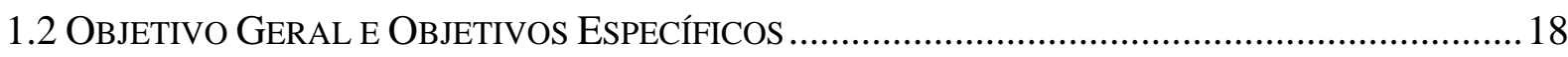

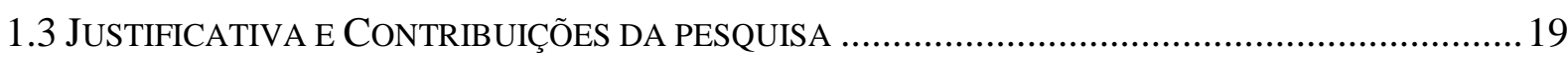

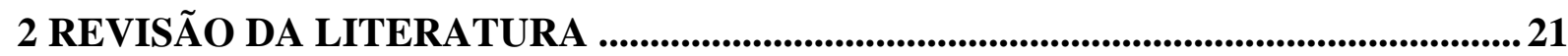

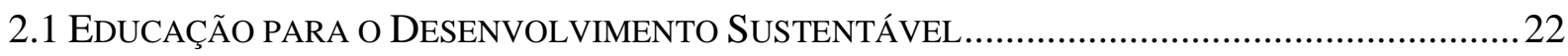

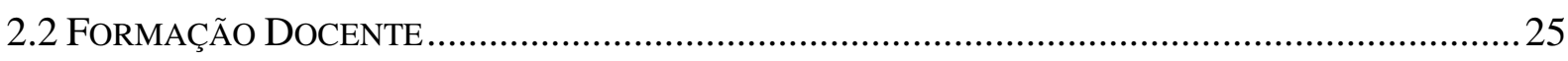

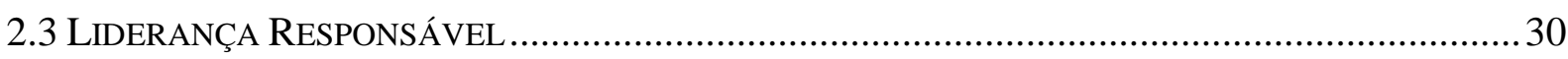

2.4 As EsColas DE NEGÓCIOS NA FormaÇão DE LÍDERES RESPONSÁVEIS ...............................33

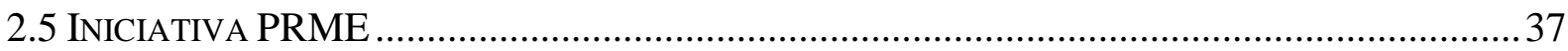

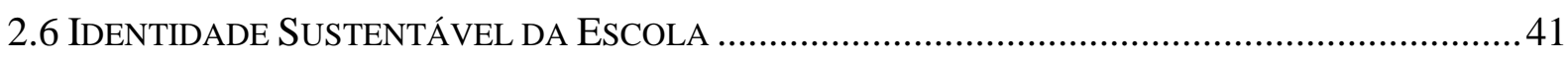

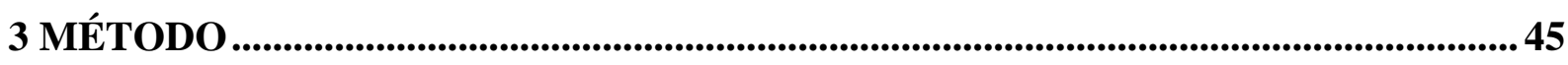

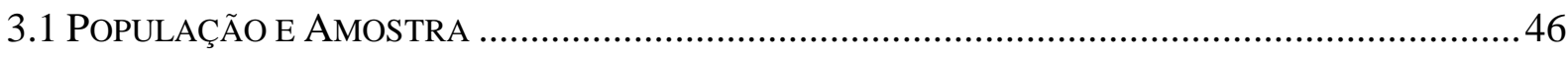

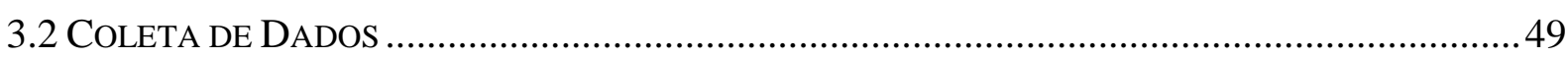

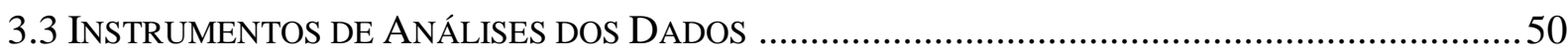

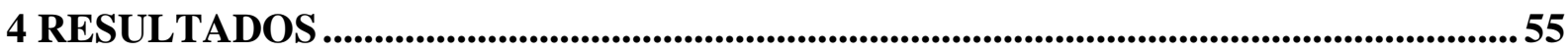

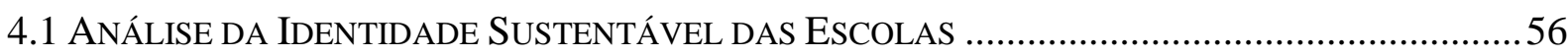

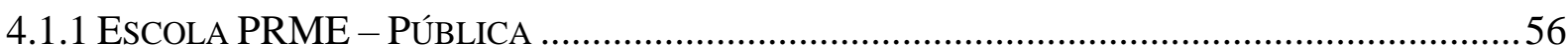

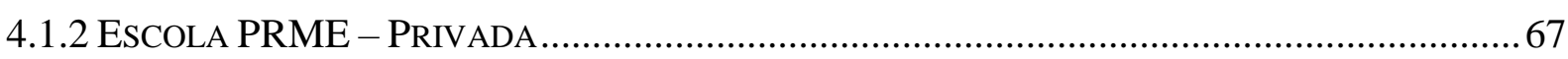

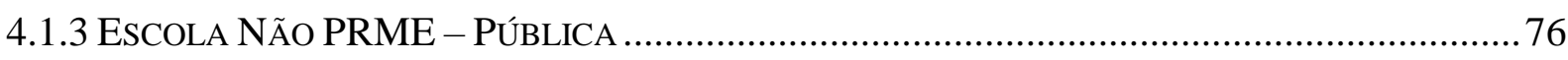

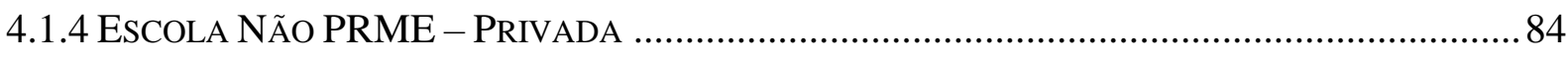

4.2 Análise da Identidade Sustentável entre as Escolas .......................................................90

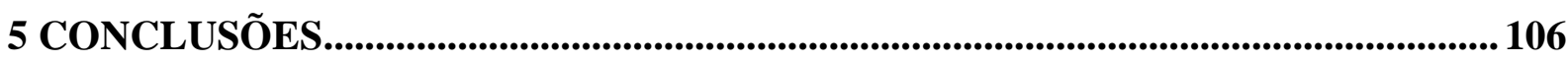

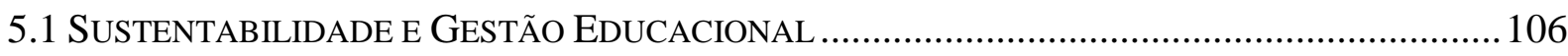

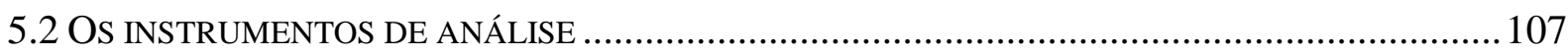

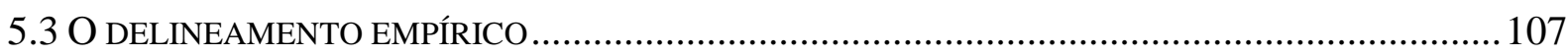

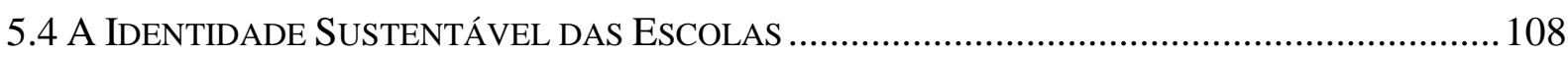

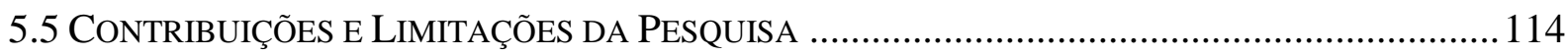

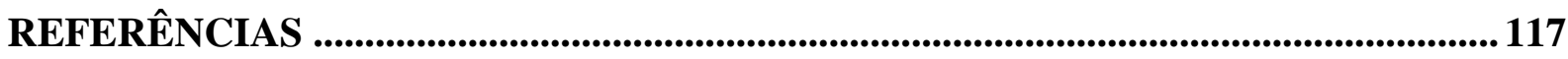

ANEXO A - AISHE 2.0 - VERSÃO D .....................................................................121 


\section{INTRODUÇÃO}

Em 2006, a Rede do Pacto Global lança um manual para nortear as escolas de negócios na formação dos gestores para desempenharem um papel de agentes de mudanças. O Principles for Responsable Management Education (PRME) se estabelece em 2007 como um conjunto de iniciativas destinadas a combater questões relacionadas a problemas sociais, ambientais e a defender a gestão educacional responsável (HAERTLE et al., 2017). Uma vez que, essas iniciativas permitem a capacitação de líderes, atuais e futuros, na geração de valores às empresas e a sociedade (HAERTLE et al., 2017).

A Organização das Nações Unidas (ONU), ao lançar o PRME disponibiliza para as escolas de negócios e as universidades um quadro norteador, de referências relacionadas à gestão, sobre a incorporação de valores universais em programas e pesquisas, construindo uma rede global para promover a sustentabilidade e responsabilidade social corporativa (PRME, 2016). Visando o fortalecimento deste quadro de referência geral, a missão do PRME é definida como sendo a de inspirar e promover a gestão e a liderança fundamentadas em valores universais, a formação de líderes para enfrentar desafios complexos da sociedade, a formação de profissionais éticos, etc. (PACTO GLOBAL, 2015). O conceito de liderança responsável, proposto pela iniciativa PRME, compreende um conjunto de partes interessadas, dentro e fora da organização, discutindo questões associadas a responsabilidade, ética no intuito de promover práticas responsáveis (MAAK; PLESS, 2006).

Por seus objetivos e missão, destaca-se a relevância do PRME como referência para a gestão educacional. Não obstante, deve-se compreendê-la, também, como uma referência que emerge dentre as referências normativas da ordem econômica. Sob este aspecto, a sustentabilidade apresenta proposições sobre a natureza, devido à sua exclusão pela racionalidade econômica na esfera da produção (LEFF, 2002). Como consequência, o conceito de sustentabilidade é apropriado pelas áreas de conhecimento em função dos diferentes ramos de negócios, transformando o desenvolvimento sustentável “... num trompe $d^{{ }^{\prime} o e i l^{l}}$ que distorce a percepção das coisas, burla a razão crítica e lança à deriva nossa atuação no mundo" (LEFF, 2002, p. 24).

A partir deste argumento, podem-se estender os "truques de perspectivas e ilusões de interpretação" aos conceitos de sustentabilidade e educação. Em relação à sustentabilidade, há a diferença entre desenvolvimento sustentável e sustentabilidade (MUNCK, 2012). Enquanto

\footnotetext{
${ }^{1}$ Expressão francesa que, com truques de perspectiva, cria uma ilusão ótica.
} 
o primeiro está atrelado à busca pela harmonia entre os aspectos ambientais, sociais e econômicos, fundamentando a noção de "Triple Bottom Line", conforme apresentado por Elkington (1997), o segundo é apreendido como utilização e consumo de recursos naturais, ou seja, a valorização dos recursos financeiros para o funcionamento da economia.

Como consequência, emerge a proposição de que as três dimensões, econômica, social e ambiental, são interdependentes (SCHRETTLE et al., 2014), o que induz ao argumento de que a organização é a alternativa para a gestão do equilíbrio entre o que é socialmente desejável, ambientalmente sustentável e economicamente viável (DIAS et al., 2011). Além disto, destaca-se que a sustentabilidade organizacional representa a capacidade das organizações alavancarem seus capitais, sejam, sociais, ambientais ou econômicos, ao contribuírem para o desenvolvimento sustentável em seu domínio político (DYLLICK; HOCKERTS, 2002).

Neste movimento de criar organizações mais sustentáveis, puxado mais fortemente por iniciativas como o Pacto Global, surge dentro do próprio Pacto Global a necessidade de se criar um movimento semelhante junto às escolas de negócios, daí a proposta de criação do PRME, visando formar líderes mais alinhados a estas organizações voltadas à sustentabilidade (HAERTLE et al., 2017).

Entretanto, não há uma uniformidade entre os conceitos de Educação para o Desenvolvimento Sustentável (EDS) ou líderes responsáveis (MAAK; PLESS, 2006). A princípio a educação é apresentada como estratégia poderosa de mudança, essencial na transformação do conhecimento em práticas de desenvolvimento sustentável (EDWARDS, 2013). Em outros termos, a educação para o desenvolvimento sustentável implica em formas de pensar e de intervir, sendo a escola o ambiente de aprendizagem, de formação e de capacitação de educadores e jovens, fomentando soluções sustentáveis para o futuro (FREITAS, 2004). As instituições são a base da promoção da gestão educacional responsável, seja por meio do ensino, da promoção da aprendizagem e da pesquisa (HAERTLE et al., 2017).

Por outro lado, como estratégia de mudança, constata-se que não está clara a resposta que os educadores e as escolas de negócios apresentam aos grupos cívicos sobre a implementação da nova consciência empresarial (HIND; WILSON; LENSSEN, 2009).

Como consequência, admite-se que a discussão sobre o papel das escolas de negócios na promoção da gestão responsável é embrionária, o que revela o descompasso com a gestão 
ambiental praticada pelas empresas, classe-mundial, do setor industrial (JABBOUR, 2014). Entretanto, se o discurso sobre educação responsável é relevante, também se constata que as escolas de negócios enfrentam muitos obstáculos para alterarem suas estruturas curriculares. Por isso, elas precisam superar uma variedade de barreiras estruturais, estratégicas e culturais. Por outro lado, há sugestões mais específicas, como a da formação de professores (FREITAS, 2004) e a reconfiguração das escolas pela formação de novos líderes em sustentabilidade e desenvolvimento (HARGREAVES, 2007).

Ao rever os argumentos apresentados, constata-se que as abordagens delimitam as investigações sobre a noção geral de sustentabilidade, sob a qual as escolas de negócios são inseridas como agente de mudança. Assim, há a apreensão da sustentabilidade sob os seus múltiplos significados. Por sua vez, o PRME permanece somente como quadro de referência inovador e como referência inovadora para a mudança. Notam-se, portanto, nesta etapa de nosso estudo, as inconsistências terminológicas de sustentabilidade, a pressuposição de mudanças inseridas pelas escolas e um modelo de mudança voltado à gestão educacional (RASCHE; GILBERT, 2015).

Assim, pode-se dizer que as escolas de negócios incorporam a sustentabilidade sob os múltiplos significados, afastando-se da inserção do modelo PRME, como estratégia de inserção de gestão educacional responsável (RASCHE; GILBERT, 2015). Em outros termos, os conceitos apresentados levam à identificação de um desacoplamento entre o modelo PRME e a apreensão deste modelo pelas escolas, sendo que esta lacuna é resultado de um contexto em que ocorre a multiplicidade de significados de sustentabilidade. Não obstante, deve-se considerar outras abordagens sobre a gestão educacional. Para Cezarino et al. (2016) é a integração entre as disciplinas o ponto negativo da gestão educacional, revelando que, a despeito das mudanças na esfera da gestão, o approach sobre o ensino não acompanha aquelas mudanças. Para tanto, há a sugestão do emprego das metodologias de soft system e interdisciplinaridade como alternativas para suprir os pontos negativos da gestão educacional.

As diferentes formas das escolas de negócio se comprometerem com o modelo PRME pode ocorrer em função das multiplicidades de significados do conceito de sustentabilidade, mas as práticas incorporadas pelas escolas de negócios podem seguir diretrizes não inovadoras (STACHOWICZ-STANUSCH, 2011). Se elas seguem outras orientações ou se seguem orientações parcialmente definidas pelo modelo PRME, emerge a necessidade de 
investigar a incorporação do modelo PRME pelas escolas de negócio e se este modelo introduz diferenças na identidade sustentável entre as escolas signatárias e não signatárias.

O conceito de identidade sustentável diz respeito a um dos módulos do modelo de gestão educacional proposto pelo Assessment Instrument for Sustainability in Higher Education (AISHE). Esse conceito compreende seis critérios que representam a identificação sustentável da escola, são eles: transparência, coerência, conhecimento, comunicação, liderança e visão e política (ROORDA et al., 2009). Assim, a avaliação da identidade sustentável em seus seis critérios, os quais são avaliados em cinco estágios na ferramenta, pode facilitar a avaliação da operacionalização do PRME na escola, demonstrando como o modelo PRME é apreendido pelos docentes e discentes das escolas investigadas (ROORDA et al., 2009).

Após esta introdução, a tese apresenta a questão que envolve a incorporação da gestão educacional responsável, delimitando os objetivos e as justificativas desta investigação. Posteriormente, há a revisão de literatura sobre os conceitos que se constituem em referências para a pesquisa em geral, estratégia necessária para a definição do conceito de identidade sustentável da escola como referência para a coleta e análise dos dados desta investigação. $\mathrm{O}$ delineamento da pesquisa é representado graficamente. Há a identificação das unidades de análise e o processo de amostragem, além da definição das análises comparativas e a identificação dos instrumentos de análise empregados. As análises dos dados seguem esta sequência, a qual direciona à conclusão e à apresentação das sugestões sobre a implementação do PRME nas escolas, visando o alcance dos objetivos do desenvolvimento.

\subsection{Problema da Pesquisa}

O emprego do termo sustentabilidade nas escolas de negócios pode ser apreendido sob diferentes perspectivas. Entre elas, a que se constitui em referência para esta investigação é a associação da sustentabilidade à gestão educacional (ALCARAZ; THIRUVATTAL, 2010; HAERTLE et al., 2017). Conceitualmente, esta perspectiva surge com o Principles for Responsible Management Education (PRME), sendo que a elaboração de indicadores de responsabilidade social universitária foi elaborada apenas em $2018^{2}$.

\footnotetext{
${ }^{2}$ PACTO GLOBAL-RED COLOMBIA. Sistema de Indicadores de Responsabilidade Social Universitária. Relatório de Progresso - PRME. Bogotá D.C. Colômbia, 2018.
} 
Tendo-se como referência o PRME, o foco da sua orientação está na gestão responsável, como um apelo global baseado em seis princípios de gestão educacional responsável (Haertle et al., 2017), a qual é disponibilizada para as instituições de ensino apenas pelos princípios amplos e pouco prescritiva quanto à forma de aplicação destes princípios nas instituições de ensino. Isto é, a transferência do modelo do PRME às instituições de ensino é definida apenas por processos generalizados, como são identificados nos princípios a seguir:

- Princípio 1 - Propósito: o propósito se constitui na incorporação do modelo educacional fundamentado pela formação do ser humano integral, líder e agente transformador da realidade.

- Princípio 2 - Valores: os valores devem ser incorporados às atividades acadêmicas, aos currículos, às metodologias e aos processos internos da escola.

- Princípio 3 - Método: a metodologia implica em adaptar métodos de ensino e aprendizagem para disseminar o conceito de sustentabilidade.

- Princípio 4 - Pesquisa: a instituição participa de pesquisa que aborda questões conceituais e empíricas para compreender o papel das corporações na criação de valores.

- Princípio 5 - Parcerias: a parceria implica em interagir com os demais atores da sociedade.

- Princípio 6 - Diálogo: o diálogo requer o estabelecimento de meios de comunicação efetivos com o ambiente externo à instituição.

Como consequência do foco do PRME no processo, não há orientação de como este processo deve ocorrer (LOUX, 2014). Portanto, a integração do PRME pelas instituições de ensino depende das iniciativas destas instituições e, sob esta pressuposição identificam-se as tendências em investigar problemas específicos, como a melhoria na aprendizagem empregando uma metodologia planejada (EDWARDS, 2013), ou a pesquisa sobre a temática ambiental constante do projeto político pedagógico, da grade de disciplinas dos cursos e perfil dos egressos (FARIAS, 2014), e a investigação sobre a transformação da gestão educacional (GODEMANN et al., 2014).

Em outros termos, as investigações privilegiam componentes do sistema educacional interno das escolas de forma isolada, sem a observância às suas articulações e nem sobre os 
fundamentados que as estruturam. Mais especificamente, o conceito que fundamenta as articulações, nesta pesquisa, é o de sustentabilidade, restringindo a sua compreensão pelo nível de identidade sustentável das escolas (Roorda et al., 2009), onde os elementos do sistema educacional investigado são o docente e discente do curso de Administração e o Projeto Político Pedagógico do Curso. Deste Projeto, os segmentos analisados são o perfil dos egressos, os objetivos do curso, as diretrizes e as disciplinas, com o objetivo de demonstrar as frequências de ocorrências, similitudes e diferenças das palavras entre os textos dos Projetos Pedagógicos dos Cursos e os do PRME.

Deste modo, esta investigação busca entender quais as percepções dos docentes e discentes sobre a identidade sustentável de escolas signatárias e não signatárias do PRME? Como consequência, busca identificar se estas percepções estão articuladas aos vocábulos dos textos dos PPCs. Tendo-se como referência o PRME, a investigação identifica a apreensão ou não dos princípios do PRME pelas iniciativas das escolas, bem como as tendências àquela incorporação, considerando as diferenças e a intensidade com que elas ocorrem. Portanto, a questão desta investigação é identificar, pelo conceito de identidade sustentável da escola, as tendências da gestão educacional das escolas investigadas, estabelecendo a correlação entre os seis princípios do PRME com os seis critérios do AISHE. A pressuposição desta correlação é que, por definição, os princípios se constituem em fundamentos sobre os quais constata-se uma proposição sobre a gestão educacional, sendo que os critérios estão implícitos como dimensões destes princípios. Em outros termos, princípios e critérios permitem a identificação de uma matriz de significados comuns, como será apresentado posteriormente.

\subsection{Objetivo Geral e Objetivos Específicos}

Ao identificar o nível de identidade sustentável das escolas de negócio brasileiras signatárias e não signatárias do PRME, pretende-se descrever as tendências da identidade sustentável na gestão destas escolas. Para tanto, os objetivos específicos passam a ser:

1. Relacionar os princípios do PRME com os critérios de identidade sustentável do AISHE.

2. Identificar e descrever os critérios e os estágios apontados pelos docentes e discentes formandos sobre a identidade sustentável das escolas.

3. Identificar e descrever os conteúdos dos segmentos constantes dos Projetos Pedagógicos dos Cursos, quais sejam: o perfil do egresso, o objetivo do curso, as 
metodologias de ensino e aprendizagem adotadas pela escola e as disciplinas curriculares, levantando similitudes e diferenças das palavras nos textos dos Projetos Pedagógicos dos Cursos.

4. Identificar e descrever as similitudes e diferenças dos resultados envolvendo os critérios e estágios de identidade sustentável das escolas pelos docentes e discentes e das palavras do PPCs e do PRME.

\subsection{Justificativa e Contribuições da pesquisa}

Com fundamento na revisão de literatura, para a elaboração desta pesquisa, identificou-se o desacoplamento entre a concepção do conceito de sustentabilidade, a formação de capacidades e as práticas dos negócios da empresa e a expectativa de que o PRME se constitua no paradigma de mudança para as escolas de negócios. Analisando o PRME, tem-se que os Princípios visam as instituições acadêmicas, promovendo a rede global para a sustentabilidade e responsabilidade social corporativa, gerando valores que orientam programas e pesquisas (PACTO GLOBAL-RED COLOMBIA, 2018).

Entretanto, o que se constata é que há um desacoplamento quando se verifica o emprego dos termos sustentabilidade, formação de capacidades e as práticas de negócios. Esses termos estão implícitos na concepção orientadora do PRME, mas se há similitude de palavras ou termos, os seus significados são diferentes, o que pode comprometer a universalização dos valores do PRME, especialmente quando a proposta é a gestão responsável da instituição (RASCHE; GILBERT, 2015).

Associado ao enquadramento conceitual da gestão responsável pela identidade sustentável da escola, há a sua operacionalização, por critérios, delimitados por estágios, permitindo identificar não somente a ocorrência da identidade sustentável da escola como a intensidade com que ela ocorre nos ambientes internos e externos a ela (ROORDA et al., 2009).

Há, portanto, diferentes fontes de informações, tais como docentes, discentes, e os Projetos Políticos Pedagógicos dos Cursos de Administração, analisados de forma articulada nos ambientes internos e externos às escolas. Sob este enfoque analítico, a principal contribuição desta investigação está na identificação da incorporação, total ou parcial, do PRME como quadro de referência para as mudanças significadas na gestão das escolas em estudo (ALCARAZ; THIRUVATTAL, 2010). 
Esta investigação ainda sobressai pelas suas contribuições às novas pesquisas. Em função dos resultados sobre a incorporação total ou parcial do PRME, é que elas poderão ser apresentadas. Primeiramente, não há estudos que busquem analisar aspectos de operacionalização dos princípios de educação responsável, e caso isso não ocorra há grande possibilidade de não incorporação destes princípios PRME pelas escolas signatárias (CABRERA, 2014). Portanto, a pesquisa contribui criando uma relação entre os princípios amplos do PRME com critérios mais objetivos de apreensão, pelo conceito de identidade sustentável.

Não obstante, pode-se supor que o PRME como quadro de referência universal, onde a incorporação dos seus princípios, operacionalizados pelos critérios e estágios aqui introduzidos (Roorda et al., 2009), é analisada, pode-se supor que a sua incorporação pelas instituições de ensino possa ser concretizada por uma rede de gestão educacional responsável, sobrepondo à relevância de atores presentes, dos projetos políticos pedagógicos e das abordagens sobre o ensino da sustentabilidade. 


\section{REVISÃO DA LITERATURA}

A investigação sobre a sustentabilidade nas escolas de negócios requer, necessariamente, a delimitação de um quadro conceitual que oriente a investigação empírica na coleta dos dados e na fundamentação das inferências. Usualmente, quando as investigações se estruturam por teorias, pela sua concepção, os conceitos se apresentam estruturados pelas relações de implicações necessárias entre eles e pelos níveis de abstração. Em outros termos, a teoria é constituida de conceitos abstratos e de conceitos menos abstratos, os quais são operacionalizados para orientar a investigação empírica (JABAREEN, 2009).

Nesta revisão de literatura, há o emprego de conceitos como o de educação para o desenvolvimento sustentável, o da formação de docentes, o de liderança responsável, o das escolas de negócios, o da formação de líderes responsáveis e, finalmente, os conceitos associados às iniciativas do PRME. Visando a construção de fundamentos para a coleta e análise dos dados, destaca-se, nesta revisão, os termos comuns a esses conceitos, mas que possuem significados idênticos, entre alguns deles, porém complementares e diferentes entre outros.

Os termos comuns ou conceitos menos abstratos se referem à sustentabilidade, à educação e aos conceitos constituintes da implicação entre sustentabilidade e educação. Isto é, assume-se que a educação é o agente indutor de mudanças em referência à sustentabilidade, como será visto nos itens seguintes, e constata-se então a emergência dos seguintes conceitos: consciência ambiental, educação ambiental, educação responsável, gestor responsável, liderança responsável, gestão educacional responsável e identidade sustentável da escola, entre outros.

Neste processo de delimitação conceitual para esta investigação, a lógica de apresentação se estrutura pelos conceitos gerais para a identificação dos conceitos específicos. Assim, a apresentação se inicia com a noção de desenvolvimento sustentável, chegando à análise do PRME, para, finalmente, concluir com um item que apresenta as identidades, complementaridades e diferenças entre os conceitos, visando o direcionamento conceitual para fundamentar as análises dos dados.

Para a construção da revisão da literatura, foram realizadas buscas nas bases de pesquisa Scopus, Scielo e Web of Science associando os termos educação para o desenvolvimento sustentável, formação docente, liderança responsável, PRME e AISHE. 


\subsection{Educação para o Desenvolvimento Sustentável}

O termo desenvolvimento sustentável emerge nos encontros e congressos internacionais ao equacionar a relação entre o crescimento populacional, a prosperidade econômica e o futuro dos recursos naturais (EDWARDS, 2013). Para o citado autor, a sustentabilidade envolve o fomento de recursos necessários para o desenvolvimento das atividades humanas.

Nesta conexão entre o uso de recursos e o desenvolvimento, "a educação constitui uma oportunidade única de criar um mecanismo que promova o desenvolvimento sustentável junto a outros valores. A educação é a primeira ferramenta para a formação de uma consciência ambiental" (EDWARDS, 2013, p. 31). Destaca-se, portanto, que a educação sobressai pela formação da consciência em relação à exploração dos recursos naturais, ênfase introduzida no relatório denominado Plano de Ação para o Meio Ambiente Humano, o qual destaca a realização das ações formais e informais, ambas ocorrendo na esfera educacional, necessárias à promoção do desenvolvimento sustentável (ONU BRASIL, 2017).

A despeito da ênfase sobre a relevância da educação, seja formal ou informal, identifica-se que os conceitos e as definições do desenvolvimento sustentável e da educação para o desenvolvimento sustentável passam a ser definidos sob múltiplos conteúdos (FREITAS, 2004). Para este autor, é importante fazer uma reflexão crítica sobre a pluralidade de significados, pois esta reflexão reforça o papel da educação para o desenvolvimento sustentável.

Para tanto, há que se destacar quatro princípios, na construção do quadro conceitual (FREITAS, 2004), sendo os princípios a referência para reforçar o papel da educação para o desenvolvimento sustentável, visando a elaboração de um programa de formação de educadores/professores. Deve-se destacar que, da concepção inicial de formação da consciência ambiental, há a proposição de sua implementação pela formação de educadores/professores.

Neste processo, o primeiro princípio se refere à conscientização dos professores para educar alunos para a participação na sociedade, visando o desenvolvimento sustentável. O segundo aponta para a integração das áreas de conhecimentos, abordando diferentes conteúdos sob a perspectiva da educação para o desenvolvimento sustentável. Por sua vez, o terceiro é voltado para a dimensão técnica do ambiente, permitindo aos alunos apreenderem conteúdos técnicos específicos à sua conservação e preservação. Assim, o quarto princípio se 
refere à formação em serviço, onde os professores podem assimilar as demandas dos alunos e desenvolver competências visando à sustentabilidade ambiental (FREITAS, 2004).

Enquanto a ênfase do desenvolvimento ambiental se centraliza na formação de professores/educadores, seguindo diretrizes específicas, há a sua complementaridade pela inclusão da proposição de uma metodologia educacional planejada, pois poucas ações são realizadas na difusão de valores associados à sustentabilidade dos recursos naturais (EDWARDS, 2013). Sob a pressuposição da formação da consciência ambiental, como necessária ao desenvolvimento sustentável, constata-se que ela, no âmbito da escola e do seu ambiente externo, depende de múltiplos fatores para se constituir em instrumento de mudança.

Em decorrência desta constatação, à educação para o desenvolvimento sustentável acrescenta-se outro componente conceitual, que é a educação ambiental, visando delimitar ações educacionais em relação ao meio ambiente. Sob esta intervenção, a educação ambiental passa a ser estruturada em formal, não formal e informal (LEONARDI, 2002). Para este autor, a educação ambiental formal é aquela que ocorre em sala de aula, possuindo metodologia, conteúdos e planejamento padronizado. Por sua vez, a modalidade não formal ocorre por meio da relação com atores sociais (parcerias), tanto no espaço público quanto no privado, como, por exemplo, pelas atividades e projetos de ONGs, de empresas, de secretarias de governo, de sindicatos e pelas intervenções isoladas dos membros das comunidades. A educação ambiental informal se caracteriza pela ausência de planejamento e de metodologias, usualmente introduzida pelos meios de comunicação como intervenções sobre questões ambientais pontuais. Como consequência, são atividades que carecem de continuidade e de conclusões sobre a solução das questões ambientais de forma efetiva.

Sob este conjunto de intervenções formais, não formais e informais destaca-se o fato de que o papel das instituições de ensino passa da formação de professores/educadores para a formação dos demais atores sociais e institucionais. Como consequência, as questões ambientais de preservação e de conservação são apreendidas pela diversidade de approachs, acrescentando a eles as abordagens interdisciplinar e multi-institucional.

Portanto, da educação para o desenvolvimento sustentável tem-se a proposição da formação da consciência ambiental e a formação de professores/educadores, a qual amplia as dimensões da educação no processo de desenvolvimento. Há a expectativa de que as instituições de ensino estejam formando profissionais capazes de trabalhar em grupos inter e 
multidisciplinares e em ações interdisciplinares na construção do conhecimento individual e coletivo (LEONARDI, 2002). Como admite o referido autor, esta proposição se constitui no grande desafio da educação para a sustentabilidade na esfera acadêmica.

Entretanto, este desafio não se concentra apenas na área acadêmica, mas torna-se mais complexo pela extensão da construção do conhecimento em sustentabilidade em outras esferas da sociedade, especialmente na área dos negócios, a qual é estruturada por fundamentos (LEONARDI, 2002; FREITAS, 2004; EDWARDS, 2013). No contexto dos negócios, a sustentabilidade é transformada em ações nas empresas, sob diferentes focos, mas considerando-se, principalmente, as oportunidades de negócios (SCHRETTLE et al., 2014). Entre esses focos pode-se destacar o uso das novas tecnologias e o desenvolvimento de novos produtos, além das intervenções de suporte à conservação e preservação do meio ambiente.

Pode-se admitir que essas mudanças resultem das demandas da sociedade, mas tendo sido construídas pelas atividades da educação ambiental sobre a consciência ambiental. Entretanto, se, por um lado o desenvolvimento sustentável expande a formação da consciência pela educação, por outro a própria educação deixa em aberto as formas e os processos de intervenções aos diferentes atores socioeconômicos e institucionais. Na esfera dos negócios, por exemplo, há a potencialização das ações estratégicas em busca de vantagem competitiva no mercado, amparada pelo conceito de responsabilidade social da organização (SCHRETTLE et al., 2014).

Sob esta proposição, entretanto, outras mudanças ocorrem no contexto da organização, como a identificação do gestor e do seu papel como moderador do processo interativo interno e externo. Destaca-se, assim, que com a introdução da noção de sustentabilidade, em termos de desenvolvimento, novos papéis na gestão da organização emergem, mas essa emergência decorre mais da demanda social, direcionada pela formação da consciência ambiental advinda do processo educacional, do que pela formação da gestão em educação ambiental.

Em outros termos, pode-se admitir que o papel da educação, no desenvolvimento sustentável, está diretamente associado à formação dos segmentos socioeconômicos e institucionais e, como consequência, incorpora valores que possam ser adequados às diferentes dimensões da sociedade. O que se apresenta, portanto, é um quadro de referência conceitual que pode ser apreendido pelos diferentes enfoques, mas que pode se constituir em referências para as pesquisas empíricas, considerando-se as especificidades dos conceitos. 
Apenas para ilustração, o Quadro 1 apresenta a síntese conceitual sobre a educação para o desenvolvimento sustentável em conformidade com os autores.

Quadro 1 - Síntese das definições discutidas - Educação para o Desenvolvimento

Sustentável

\begin{tabular}{|l|l|l|}
\hline \multicolumn{1}{|c|}{ Problema Investigado } & \multicolumn{1}{|c|}{ Proposições } & \multicolumn{1}{c|}{ Autor(es) } \\
\hline $\begin{array}{l}\text { Caracterização da educação ambiental } \\
\text { em formal, não formal e informal. }\end{array}$ & $\begin{array}{l}\text { Universidade trabalha com grupos } \\
\text { multidisciplinares e em ações } \\
\text { interdisciplinares. }\end{array}$ & Leonardi (2002) \\
\hline $\begin{array}{l}\text { Múltiplos significados de } \\
\text { sustentabilidade e educação. }\end{array}$ & $\begin{array}{l}\text { Introdução da reflexão crítica, } \\
\text { criando consensos conceituais. } \\
\text { Identifica princípios na formação } \\
\text { de educadores: participação } \\
\text { social; integração das áreas de } \\
\text { conhecimento; conteúdos técnicos } \\
\text { ambientais; formação em serviços. }\end{array}$ & \\
\hline $\begin{array}{l}\text { Sustentabilidade como dimensão do } \\
\text { desenvolvimento }\end{array}$ & $\begin{array}{l}\text { Educação como instrumento de } \\
\text { formação de consciências. }\end{array}$ & Edwards (2013) \\
\hline $\begin{array}{l}\text { Sustentabilidade e sua transformação em } \\
\text { ações na empresa }\end{array}$ & $\begin{array}{l}\text { Dimensão ecológica influencia a } \\
\text { dimensão social e ambas devem } \\
\text { ser operacionalizadas como } \\
\text { oportunidades de negócio. }\end{array}$ & \\
\hline
\end{tabular}

Fonte: Elaborado pela autora

Como síntese, o objetivo do Quadro 1 é o de ressaltar problemas e proposições dos autores, as quais se constituíram em referências para a apreensão da educação no processo de desenvolvimento sustentável. Um dos aspectos essenciais é a necessidade de reflexão crítica sobre o tema, em virtude da complexidade de atores e instituições envolvidas nos processos que integram a educação e o desenvolvimento sustentável. Como consequência, destaca-se a sustentabilidade incorporada pelo desenvolvimento e as implicações associadas a esta incorporação, envolvendo os múltiplos atores, instituições e seus interesses, como a introdução da sustentabilidade no contexto dos negócios da organização.

\subsection{Formação Docente}

A formação docente também é um tema amplo, abordado a partir de diferentes quadros interpretativos e construído sob unidades analíticas distintas. Sob a perspectiva da formação docente no Brasil, a abordagem geral são as políticas educacionais, instruindo as diretrizes curriculares para os cursos de licenciatura (PEREIRA, 1999). De forma alternativa, há o emprego da abordagem sobre as políticas inclusivas na educação, focalizando a formação docente para a educação especial. Para tanto, a referência é o Plano Nacional de Educação, o 
Programa Educação Inclusiva, os Cursos de Aperfeiçoamento de Professores do Atendimento Educacional Especializado e o Programa de Implantação de Salas de Recursos Multifuncionais, além da Política Nacional de Educação Especial na Perspectiva da Educação Inclusiva (GARCIA, 2013).

As abordagens sobre diretrizes curriculares, políticas e programas permitem apreender a formação docente pela institucionalização das orientações, necessárias para as intervenções na formação docente. Há, assim, diretrizes na formação de professores da educação básica, na formação de profissionais da educação, na formação profissional para a educação infantil, na formação de professores e as novas tecnologias de comunicação e informações, na formação para o ensino à distância, etc.

Deve-se destacar que o enfoque desta abordagem é sobre diretrizes, o que induz à reflexão crítica sobre as práticas dos docentes e as suas adequações à instituição, e a flexibilidade dos docentes em apreendê-las e em adquiri-las (TARDIF, 2002). Neste contexto, a formação docente ocorre como sendo estruturada pelos incentivos à formação continuada, a oferta de cursos de especialização, a ocorrência de eventos, palestras, seminários atualizados, os quais dependem de apoio financeiro das organizações governamentais e não governamentais, além do apoio financeiro às participações programadas e a oportunidade de desenvolver projetos de pesquisa e atividades de extensão universitária (TARDIF, 2002).

O que se infere é que estas abordagens investigam a formação docente a partir de diferentes objetos e unidades de análises. Uma dessas análises, por exemplo, pode se restringir à formação da docência superior em metodologias de ensino, restringindo-a aos cursos de pós-graduação (ANASTASIOU, 2003; MASETTO, 2012). Este estudo pressupõe que a didática é uma área de conhecimento que trabalha com formas de ensinar, introduzindo componentes teóricos, técnicos e operacionais, os quais habilitam o profissional a ser professor. Não obstante, um dos resultados encontrados é que a disciplina de metodologia de ensino, com carga horária de 60 horas de atividades, é relativamente pequena, em relação às demais disciplinas dos cursos, o que se constitui em um ponto crítico na formação docente (ANASTASIOU, 2003; MASETTO, 2012).

Em relação à análise das diretrizes para os cursos de administração, a referência é a Lei de Diretrizes e Bases da Educação Nacional, em que as diretrizes para o exercício do magistério superior, nos programas de mestrado e doutorado stricto sensu, acentuam a ênfase sobre a pesquisa mais do que sobre o ensino, pois a estrutura curricular direciona para esta 
formação (VIEIRA, 2014). Portanto, os estudos sobre a formação para a docência, seja ela em geral ou específica da Administração, constatam a mesma tendência, ou seja, o não fortalecimento da formação pelas metodologias de ensino, as quais abordam estratégias, técnicas, atividades e processos de aprendizagem em diferentes ambientes.

A despeito da lacuna da formação docente pela disciplina de metodologia de ensino, há a tendência em categorizar os professores no ensino superior em administração, classificando-os pela experiência docente e pela vivência gerencial (SOUZA-SILVA; DAVEL, 2005). Com base nessas duas dimensões, há quatro tipos de professores no ensino da administração, quais sejam:

a) Professores com alta experiência docente e alta vivência gerencial.

b) Professores com alta experiência docente e carência de vivência gerencial.

c) Professores com baixa experiência docente e alta vivência gerencial.

d) Professores com baixa experiência docente e baixa vivência gerencial.

Pelas categorias empregadas nesta tipologia, o enfoque é pelo tempo na atividade docente e na atividade de gerência, desconsiderando a estrutura do curso pelas disciplinas pedagógicas e pela prática profissional docente (TARDIF, 2002). Portanto, o que se infere da formação docente é a complexidade de fatores intervenientes nesta formação, seja de forma geral para as áreas de conhecimento, seja específico em Administração pela inclusão de disciplinas optativas, no geral, sobre sustentabilidade e as dimensões socioeconômicas dos negócios. O propósito se direciona mais para o atendimento das demandas sociais do que para a mudança na gestão sustentável educacional.

A tendência é assumir a educação como indutora de mudanças, e que a instituição de ensino é responsável, e promotora, pela construção do conhecimento e de valores sobre a responsabilidade ambiental (FIGUEIREDO; GUERRA; CARLETTO, 2014). Por isso, a relevância da instituição de ensino em:

a) Incorporar a temática ambiental e da sustentabilidade socioambiental.

b) Identificar os avanços sobre a introdução da temática nos currículos, na gestão e no planejamento territorial dos campus.

c) Instituir parcerias institucionais.

d) Apresentar proposições para as políticas públicas sobre educação ambiental. 
O que se destaca é que, sob este contexto complexo da formação docente, a questão ambiental é introduzida nos cursos de administração, onde as análises continuam a focalizar o projeto político pedagógico e as matrizes curriculares dos cursos, além dos perfis dos egressos, com os conteúdos voltados para as temáticas ambientais e da sustentabilidade (FARIAS, 2014). Nota-se que a questão ambiental é introduzida nos cursos de graduação sob o enfoque de sustentabilidade associado ao desenvolvimento econômico, em virtude das demandas da sociedade, decorrente da degradação dos recursos naturais (SÁENZ, 2014).

De forma direcionada, a área de administração passa a ser objeto de investigação, visando à identificação dos dilemas e desafios para inserir sustentabilidade nos currículos dos cursos, onde o objetivo é a formação de futuros administradores (GONÇALVES-DIAS; HERRERA; CRUZ, 2013). Deve-se explicitar que a tendência deixa de ser professores/educadores para focalizar os administradores, sob o propósito de mudar o comportamento dos empresários e administradores em relação às novas demandas sociais sobre a gestão na empresa e a sustentabilidade social e ambiental (GONÇALVES-DIAS; HERRERA; CRUZ, 2013).

Portanto, a sustentabilidade social e ambiental passa a ter componente conceitual da gestão, mas delimitada pelo foco sobre os recursos naturais, principalmente. Neste sentido, sobressai a sustentabilidade pelas oportunidades dos negócios, como práticas a serem consideradas pelos empresários e administradores em função das variáveis econômicas, como despesas e custos (SOUZA-SILVA; DAVEL, 2005).

Sob esta conotação, o termo sustentabilidade se afasta do conceito de sustentabilidade introduzido pela educação ambiental como estratégia de disseminação de práticas conservacionistas e de preservação dos recursos naturais. Como consequência, a sustentabilidade na empresa se associa à sustentabilidade corporativa, afastando-se das ações pontuais, como responsabilidade social, passando a proposições de longo prazo para clientes, funcionários e a sociedade, visando à redução de impactos ambientais, a contribuição social e a atuação ética (MUNCK, 2012). O Quadro 2 apresenta a síntese dos problemas e proposições apresentadas pelos autores sobre a formação docente.

Quadro 2 - Síntese das definições discutidas - Formação docente

\begin{tabular}{|l|l|l|}
\hline \multicolumn{1}{|c|}{ Problema Investigado } & \multicolumn{1}{|c|}{ Proposições } & \multicolumn{1}{|c|}{ Autor(es) } \\
\hline Políticas educacionais & $\begin{array}{l}\text { Investiga as políticas educacionais para } \\
\text { a formação docente no Brasil, }\end{array}$ & \\
\hline & enfatizando os currículos para a análise
\end{tabular}




\begin{tabular}{|c|c|c|}
\hline & das formações. & \\
\hline $\begin{array}{l}\text { Reflexão crítica sobre as práticas } \\
\text { docentes }\end{array}$ & $\begin{array}{l}\text { Defende a necessidade da reflexão } \\
\text { crítica sobre as práticas docentes, } \\
\text { deliberando aos docentes a } \\
\text { flexibilidade em adquiri-las e implantá- } \\
\text { las, em conformidade com os contextos } \\
\text { da instituição educacional. }\end{array}$ & Tardif (2002) \\
\hline Preparação para a docência superior & $\begin{array}{l}\text { Restringem à análise da preparação } \\
\text { para a docência superior, e não à } \\
\text { formação docente, nos desenhos dos } \\
\text { programas de pós-graduação. }\end{array}$ & $\begin{array}{l}\text { Anastasiou (2003) } \\
\text { Masetto (2012) }\end{array}$ \\
\hline $\begin{array}{l}\text { Tipologias dos professores no ensino } \\
\text { superior em administração }\end{array}$ & $\begin{array}{l}\text { A tipologia é construída sobre duas } \\
\text { dimensões; a experiência docente e a } \\
\text { vivência gerencial. }\end{array}$ & Souza-Silva; Davel (2005) \\
\hline Responsabilidade corporativa & $\begin{array}{l}\text { Pode ser integrada nas disciplinas de } \\
\text { administração e não abordar os } \\
\text { conteúdos separadamente. }\end{array}$ & $\begin{array}{l}\text { Hind; Wilson; Lenssen } \\
\text { (2009) }\end{array}$ \\
\hline Educação especial & $\begin{array}{l}\text { Investiga a formação docente para a } \\
\text { educação especial, tendo como } \\
\text { referência empírica o Plano Nacional } \\
\text { de Educação, o Programa Educação } \\
\text { Inclusiva, os } \text { Cursos de } \\
\text { Aperfeiçoamento de Professores do } \\
\text { Atendimento } \\
\text { Especializado. }\end{array}$ & Garcia (2013) \\
\hline Dilemas e desafios na Educação & $\begin{array}{l}\text { Investigam os dilemas e desafios para } \\
\text { inserir sustentabilidade nos currículos } \\
\text { de Administração. }\end{array}$ & $\begin{array}{l}\text { Gonçalves-Dias; Herrera; } \\
\text { Cruz (2013) }\end{array}$ \\
\hline $\begin{array}{l}\text { O ensino de administração baseado } \\
\text { em competências }\end{array}$ & $\begin{array}{l}\text { Assume que a formação nos níveis de } \\
\text { pós-graduação é em pesquisa e não no } \\
\text { ensino }\end{array}$ & Vieira (2014) \\
\hline Ênfase nas temáticas & $\begin{array}{l}\text { Evidencia que a formação em } \\
\text { ambientalização ocorre por meio do } \\
\text { ensino, da pesquisa e da extensão } \\
\text { universitária. }\end{array}$ & Farias (2014) \\
\hline Demanda da sociedade & $\begin{array}{l}\text { Evidencia que a formação em } \\
\text { ambientalização ocorre por meio da } \\
\text { demanda da sociedade }\end{array}$ & Sáenz (2014) \\
\hline Papel da Universidade & $\begin{array}{l}\text { É a universidade que se institui, } \\
\text { inicialmente, como responsável e } \\
\text { promotora da construção do } \\
\text { conhecimento }\end{array}$ & $\begin{array}{l}\text { Figueiredo;Guerra; } \\
\text { Carletto (2014) }\end{array}$ \\
\hline Gestão da educação responsável & $\begin{array}{l}\text { PRME se constitui em referência para a } \\
\text { transformação da gestão educacional, } \\
\text { visando a corporação cidadã, a } \\
\text { corporação com responsabilidade } \\
\text { social e sustentabilidade ambiental. }\end{array}$ & Golemann et al. (2014) \\
\hline
\end{tabular}

Fonte: Elaborado pela autora

A síntese apresentada no Quadro 2 destaca as trajetórias dos estudos sobre a formação docente que se inicia nas instituições de ensino e se estende à formação de gestores nas organizações. São trajetórias distintas, sendo a do docente orientada, inicialmente pelas políticas educacionais e legislação, e a de gestores orientada para atenderem às demandas da 
sociedade. Não obstante, ambas possuem em comum a dimensão ambiental pela degradação dos recursos, mas elas diferem pelos fundamentos que orientam as suas práticas. Para uma, o foco é educacional, e para a outra a ênfase está na corporação sustentável.

\subsection{Liderança Responsável}

A abordagem sobre liderança nas organizações enfatiza tanto o papel das pessoas, e seus seguidores, como a própria organização em relação ao ambiente externo (NORTHOUSE, 2004). Em relação aos seguidores, destacam-se as relações de comprometimento, e em relação à organização o foco é a sustentabilidade do ambiente, com o fortalecimento das dimensões econômicas e financeiras (MINUZZI; FILHO; SANTOS, 2009). Em ambas as situações, o líder possui influência e poder, capacidades que podem direcionar comportamentos sob diferentes propósitos. Portanto, é em função do exercício desta capacidade que surge o termo responsável.

$\mathrm{O}$ termo liderança consciente surge ao final do século $\mathrm{XX}$ como predecessor do conceito de liderança responsável (CHATTERJEE, 1998) que se fortalece com o propósito de contribuir para o debate do desenvolvimento sustentável, uma vez que a preocupação das empresas não está restrita a questão econômica, mas na capacidade de preservar o aspecto ambiental e contribuir para o bem-estar da sociedade (MAAK; PLESS, 2006). Dessa forma, o propósito da liderança responsável pode ser compreendido como forma de contribuir para o desenvolvimento sustentável e cultivar relações de confiança entre as partes interessadas, dentro e fora das organizações, ou seja, manter e garantir boas relações com todo os stakeholders (MAAK; PLESS, 2006).

A princípio, têm-se as descrições sobre as características da responsabilidade, como por exemplo, "um líder responsável deve ter clareza quanto aos valores assumidos, considerações morais quanto ao exercício do poder, concepções sobre justiça e julgamentos éticos, que geralmente afetarão a seleção dos objetivos e metas que o grupo deve seguir" (MINUZZI; FILHO; SANTOS, 2009, p. 21). De forma alternativa, as características do líder responsável, sob os propósitos de mudança da organização, devem revelar aspectos sobre as dimensões econômicas, ambientais e sociais (HARGREAVES; FINK, 2003). Entre outras características, o líder responsável deve ser capaz de desenvolver relacionamentos próximos e duradouras, além de estabelecer relações de confiança entre as pessoas (MAAK; PLESS, 2006). Assim, a liderança deve contribuir tanto para o ambiente interno quanto para o externo. 
De forma geral, há algumas características que se destacam, em relação à liderança responsável (HARGREAVES, 2007):

1. Liderança responsável é uma proposição moral.

2. Liderança responsável preserva e introduz valores ao longo do tempo.

3. Liderança responsável depende de outras lideranças.

4. Liderança responsável melhora o meio ambiente

5. Liderança responsável promove coesão entre as diversidades.

6. Liderança responsável não degrada recursos materiais e humanos.

7. Liderança responsável valoriza e aprende o que de melhor ocorreu no passado, visando à criação de um futuro melhor.

A despeito da identificação destas características, pode-se assumir que não existem traços ou referências de líderes universais. Há contextos ou situações em que a liderança emerge e outros em que ela se adapta ou se reestrutura ${ }^{3}$. Isto se aplica tanto à liderança interna quanto externa à organização. Especificamente sobre a dimensão externa, que se destaca pela sua relevância neste estudo, a liderança da organização passa a se estruturar pelo sistema de governança, visando à excelência na gestão. Assim, se o ambiente externo requer gestão responsável, como é a questão global sobre a sustentabilidade, a organização passa a assumir este compromisso, caso contrário ela se insere em uma situação em que a organização separa os seus compromissos de suas práticas (SNELSON-POWELL; GROSVOLD; MILLINGTON, 2016).

A liderança responsável é, portanto, apreendida pela mudança de comportamentos. Esta mudança tanto pode estar atrelada às demandas da sociedade, como usualmente são referenciadas nos processos de mudanças, quanto às demandas associadas às questões globais. A diferença entre uma e outra está na delimitação de sua natureza, ou seja, as da sociedade se apresentam de forma generalizada, como a degradação do meio ambiente, e as globais são mais específicas, como a responsabilidade sustentável, que se estende aos fatores sociais internos e externos à organização, econômicos da empresa, internos e externos à empresa e ambientais, como a preservação e conservação dos recursos.

\footnotetext{
${ }^{3}$ Outra alternativa interpretativa está no delineamento de modelos de liderança pela organização (LILI; MO; XIAOXIAO, 2009).
} 
O que se destaca é que, enquanto essas demandas podem ser diferenciadas pela origem e extensão em suas concepções, assume-se, nesta investigação, que, em ambas as situações, elas ocorrem pela mudança comportamental educacional. Não obstante, é a origem e a extensão em suas concepções que irão determinar a natureza das intervenções, e não o simples emprego de estratégias e de formações associadas às mudanças comportamentais. Por exemplo, a formação de liderança pode ser responsável ao fazer uso dos recursos naturais para a inserção da empresa em novas oportunidades de negócios, mas não ser responsável quanto à preservação desses recursos ou à exploração da mão de obra sob bases não legais, ou mesmo sob a não ocorrência de transparência na realização de contratos, etc.

Neste sentido, a proposição de que pela educação pode-se criar o futuro e conservar o passado (HARGREAVES, 2007) requer melhor compreensão quando empregada para fundamentar a mudança comportamental nas organizações. Seguindo este raciocínio, formar lideranças pela mudança de comportamento também depende da concepção da natureza e extensão das mudanças a serem implementadas, pois liderança e líderes formados pela sustentabilidade do desenvolvimento econômico requerem a assimilação de determinados fundamentos, do mesmo modo que liderança e líderes em gestão educacional, em responsabilidade social, etc., requerem a assimilação de outros fundamentos.

Em conformidade com os argumentos apresentados nessa revisão de literatura, podese considerar que o conhecimento em sustentabilidade, pelos fundamentos, proposições e ações associadas a ela, constitua-se em referência para a orientação da mudança comportamental em gestão educacional. Em outros termos, assume-se que a apreensão dos princípios para a educação responsável esteja, na percepção dos docentes e discentes das escolas signatárias e não signatárias do PRME, bem como pelos projetos pedagógicos dos seus cursos, direcionada para instituir uma gestão responsável, visando o alcance da liderança institucional no seu ambiente externo. É sob este propósito que o tema liderança é aqui introduzido, o qual pode ser sintetizado, pelos problemas e proposições dos seus autores, no Quadro 3.

Quadro 3 - Síntese das definições discutidas - Liderança Responsável

\begin{tabular}{|l|l|l|}
\hline \multicolumn{1}{|c|}{ Problema Investigado } & \multicolumn{1}{|c|}{ Proposições } & \multicolumn{1}{c|}{ Autor(es) } \\
\hline Mudança na organização & $\begin{array}{l}\text { Líder modifica atitudes e } \\
\text { comportamentos. A liderança } \\
\text { responsável tornar-se um compromisso } \\
\text { de todos os líderes. }\end{array}$ & Hargreaves; Fink (2003) \\
\hline
\end{tabular}




\begin{tabular}{|l|l|l|}
\hline Conceito de liderança & $\begin{array}{l}\text { Constituição por variáveis econômicas, } \\
\text { sociais e psicológicas. }\end{array}$ & Northouse (2004) \\
\hline Liderança responsável & $\begin{array}{l}\text { O líder responsável deve ser capaz de } \\
\text { garantir relações próximas e duradouras } \\
\text { entre as partes interessadas. }\end{array}$ & Maak; Pless (2006) \\
\hline $\begin{array}{l}\text { Adequação da escola, } \\
\text { professores e o ensino à } \\
\text { economia do conhecimento }\end{array}$ & $\begin{array}{l}\text { Identifica sete princípios de } \\
\text { sustentabilidade para introduzir a } \\
\text { mudança educacional e a formação de } \\
\text { líderes. }\end{array}$ & Hargreaves (2007) \\
\hline Características do líder & $\begin{array}{l}\text { Comprometimento com os seguidores, } \\
\text { possui influência e usa o poder. }\end{array}$ & Minuzzi; Filho; Santos (2009) \\
\hline Liderança nas empresas & $\begin{array}{l}\text { Desenhar modelos de liderança é } \\
\text { relevante para a empresa. }\end{array}$ & Lili, Mo; Xiaoxiao (2009) \\
\hline Gestão responsável & \begin{tabular}{l} 
Papel da organização. \\
Snelson-Powell;Grosvold; \\
\hline
\end{tabular}
\end{tabular}

Fonte: Elaborado pela autora

O Quadro 3 não se constitui em uma síntese exaustiva sobre liderança e liderança responsável. O que se destaca é a identificação de algumas proposições e problemas investigados que fundamentam a elaboração do quadro conceitual a ser empregado na análise e interpretação dos dados. O objetivo da abordagem apresentada fundamenta-se na relevância em investigar a liderança sob diferentes conteúdos, inclusive como modelo a ser elaborado pela própria empresa. Não obstante, como o objeto de análise é a instituição de ensino, apreendida pela sustentabilidade na sua gestão, torna-se relevante destacar que liderança individual, de grupos ou de instituições requerem mudanças de comportamento, e não se restringem apenas aos traços individuais. Além disto, institucionalmente essas mudanças são extensivas e requerem comprometimento, ao se envolverem com as questões globais.

\subsection{As Escolas de Negócios na Formação de Líderes Responsáveis}

Esse item apresenta as tendências nas escolas de negócios sob o conhecimento em sustentabilidade e se as mesmas seguem as orientações na educação para o desenvolvimento, na formação dos docentes e nas lideranças responsáveis. Para tanto, identifica-se, inicialmente, que a responsabilidade corporativa pode ser integrada nas disciplinas dos cursos de administração, onde os mesmos conceitos são abordados pelas diferentes disciplinas (HIND; WILSON; LENSSEN, 2009). Por exemplo, disciplinas como finanças e contabilidade devem envolver conteúdos sobre transparência. Sob a mesma orientação, disciplina de marketing deve incorporar, como conteúdo, as causas e consequências das parcerias e a disciplina de comportamento organizacional pode abordar os estilos de lideranças e os seus impactos sobre os comportamentos nas organizações. 
Outra abordagem proposta às escolas de negócios é a de inserir os valores sociais, da organização e os ecológicos, na gestão das escolas, o que passa a requerer ações estratégicas (FORRAY; LEIGH, 2012).

Nota-se que, entre as duas proposições descritas, elas podem ser consideradas como complementares, onde a alternância na gestão pode induzir ao emprego de temas sustentáveis, de forma transversal, nas disciplinares do curso. Portanto, segue a proposição de que o conhecimento em sustentabilidade requer mudança de comportamento.

Esta proposição reforça o papel da educação, o que é inquestionável, no desenvolvimento sustentável, na formação do próprio professor/educador e de líderes responsáveis. Entretanto, o que se ressalta é o conhecimento sobre sustentabilidade, e os valores, atitudes, habilidades e competências gerados em cada uma dessas dimensões. Por exemplo, sob a perspectiva educacional do desenvolvimento sustentável o enfoque é o socioeconômico e o uso dos recursos naturais. Por sua vez, a sustentabilidade na formação do docente visa à formação da consciência ambiental, fundamentada pela disponibilidade dos recursos naturais, ao longo do tempo, e a sua conservação.

Essas duas dimensões permitem extensões conceituais e de intervenções para as diferentes áreas de conhecimento, e é sob esta extensão que emergem os valores de responsabilidades, com diferentes significados, os quais são apreendidos convenientemente, em função dos seus interesses. Portanto, as escolas de negócios demonstram estar sob influências múltiplas, resultando em engajamentos distintos, das instituições, aos valores, atitudes, conhecimentos e a habilidades.

O que se destaca é que, além da diversidade de significados sobre o conhecimento em sustentabilidade, há também o desacoplamento em termos de engajamentos e as condições em que eles ocorrem, considerando, principalmente, as capacidades internas destas instituições para a mudança (RASCHE; GILBERT, 2015). Para esses autores, o desacoplamento entre as questões globais de sustentabilidade e a sua inclusão nas práticas das instituições está associada aos seguintes fatores: a) restrição de recursos financeiros; b) resistência ao processo de mudança; c) concorrência entre as instituições; e d) demanda ambígua.

Portanto, entre a criação de disciplinas e/ou a introdução transversal dos temas nas disciplinas do curso, e a constatação do desacoplamento entre o quadro de referência sobre as práticas organizacionais e educacionais recomendadas e as realizadas pelas instituições, há a ausência de análises críticas sobre as mudanças necessárias nas instituições (LOUX, 2014). A 
consequência é assumir a pressuposição de que quadros de referências para a mudança na organização e gestão das escolas passem a ser considerados apenas como iniciativas para as mudanças nos currículos e nas práticas de ensino aprendizagem (STACHOWICZSTANUSCH, 2011).

Como iniciativa isoladas no processo de mudança das escolas, porém, elas começam a ser empiricamente analisadas pelos relatórios de atividades das instituições, o Sharing Information Progress (SIP), no caso das signatárias do PRME. Sob este quadro de referência, o primeiro princípio analisado foi operacionalizado pelas iniciativas dos estudantes em participarem de entidades, organizações, conferências e workshops, além de elaborarem projetos para as empresas (STACHOWICZ-STANUSCH, 2011). A partir das análises, a autora conclui que se deve deixar a seguinte questão em aberto: por que e o que ensinar aos futuros líderes empresariais para tê-los melhor preparados para enfrentarem os desafios de liderar com integridade no ambiente global?

Nota-se que a sugestão sobre o ensino focaliza as disciplinas, em conformidade com a mudança na instituição, apenas por esta dimensão. Não obstante, ao considerar os novos valores que emegem no PRME, há a delimitação de uma nova visão do papel do admistrador na sociedade (CABRERA, 2014). Portanto, se esses papéis afetam todos os setores da empresa, a preparação dos estudantes como futuros difusores de valores de sustentabilidade passa a ser complexa. Por isso ocorre, o comprometimento institucional das escolas de negócios com a agenda da sustentabilidade, mas sem o seu envolvimento com as práticas (SNELSON-POWELL; GROSVOLD, 2016).

É interessante acrescentar que, devido às constatações e argumentos apresentados sob este item, verifica-se dois tipos de desacoplamentos, ou seja, tanto o desacoplamento entre o engajamento da instituição e a sua prática, quanto entre o conhecimento em sustentabilidade e a gestão educacional. Enquanto a primeira enfatiza as pressões institucionais sobre as escolas de negócios, a segunda retrata a incorporação da sustentabilidade nestas escolas. Assim, às restrições institucionais apresentadas pelos gestores (RASCHE; GILBERT, 2015), junta-se a descrição de como a agenda é apreendida pelos docentes, discentes e incorporadas nos Projetos Pedagógicos dos Cursos, conforme apresentado na definição do problema a ser aqui investigado. A síntese dos problemas e proposições dos autores que levam a esta fundamentação está apresentada no Quadro 4. 
Quadro 4 - Síntese das definições discutidas - As escolas de negócio na formação de líderes responsáveis

\begin{tabular}{|l|l|l|}
\hline \multicolumn{1}{|c|}{ Problema Investigado } & \multicolumn{1}{|c|}{ Proposições } & \multicolumn{1}{|c|}{ Autor(es) } \\
\hline Responsabilidade corporativa & $\begin{array}{l}\text { Pode ser integrada nas disciplinas de } \\
\text { administração e não abordar os conteúdos } \\
\text { separadamente. }\end{array}$ & $\begin{array}{l}\text { Hind; Wilson; Lenssen } \\
(2009)\end{array}$ \\
\hline Investiga escolas de negócios & $\begin{array}{l}\text { O que ensinar e por que ensinar os futuros } \\
\text { líderes empresariais para tê-los melhor } \\
\text { preparados para enfrentar os desafios de } \\
\text { liderar com integridade no ambiente global } \\
\text { é uma questão em aberto. }\end{array}$ & Stachowicz-Stanusch (2011) \\
\hline $\begin{array}{l}\text { Análise crítica da gestão } \\
\text { educacional responsável }\end{array}$ & $\begin{array}{l}\text { Não há gestão irresponsável. A inserção de } \\
\text { novos valores é estratégica. }\end{array}$ & Forray; Leigh (2012) \\
\hline Análise crítica do PRME & $\begin{array}{l}\text { PRME é um paradigma para a mudança, } \\
\text { mas não há análises críticas. }\end{array}$ & Loux (2014) \\
\hline Análise crítica do PRME & $\begin{array}{l}\text { O vácuo entre a formação de capacidades } \\
\text { e as práticas dos negócios da empresa deve } \\
\text { ser superado. }\end{array}$ & Cabrera (2014) \\
\hline $\begin{array}{l}\text { Criticam estudos exploratórios e } \\
\text { descritivos sobre o PRME }\end{array}$ & $\begin{array}{l}\text { Os relatórios dos signatários no Sharing } \\
\text { Informationon Progress não são fontes de } \\
\text { informações suficientes para a a } \\
\text { compreensão da associação entre formação } \\
\text { de capacidades e práticas dos negócios. }\end{array}$ & Godemann et al. (2014) \\
\hline $\begin{array}{l}\text { Desacoplamento sobre o termo } \\
\text { sustentabilidade e as práticas } \\
\text { das escolas }\end{array}$ & $\begin{array}{l}\text { Diversidade de significados sobre o } \\
\text { conhecimento em sustentabilidade. }\end{array}$ & Rasche; Gilbert (2015) \\
\hline Comprometimento institucional & $\begin{array}{l}\text { Papel da organização. } \\
\text { Fongelson-Powell; Grosvold; }\end{array}$ \\
\hline
\end{tabular}

Fonte: Elaborado pela autora

A síntese apresentada no Quadro 4 revela a complexidade com que se insere a escola de negócios na incorporação da agenda global sobre sustentabilidade. Os autores ilustram a incorporação por temas transversais, por disciplinas, e pela demonstração das atividades realizadas pelos estudantes. Esses argumentos são inferidos a partir de dados secundários, os quais, complementados por dados primários, permitem compreender mais adequadamente a complexidade institucional em que estão inseridas as escolas de negócios.

O importante é que essas abordagens permitem expor a relevância do problema investigado nesta pesquisa, especialmente pela forma como os itens anteriores retratam o papel da educação no processo de mudança. Isto é, eles permitem contrapor a mudança de comportamento como consequência da educação com a mudança de comportamento necessária à gestão educacional responsável. Enquanto a primeira forma consciência ambiental, educa e forma líderes responsáveis, a segunda focaliza a gestão das escolas frente às questões globais de sustentabilidade. 
É neste sentido que se constrói o quadro de referência conceitual desta pesquisa. Ele se reestrutura pela iniciativa do PRME, como é demonstrado no item seguinte, permitindo identificar os argumentos que fundamentam as diferenças entre as mudanças de comportamentos nas pessoas, na sociedade, nos líderes e aquelas necessárias à gestão educacional. Após a descrição dos argumentos do PRME, a tarefa seguinte é estruturar os conceitos pelas semelhanças de significados e introduzir o conceito de identidade sustentável da escola como referência para a coleta e análise dos dados.

\subsection{Iniciativa PRME}

A origem do Principles for Responsible Management Education, PRME, insere-se numa chamada global das Nações Unidas para a gestão responsável em educação sob valores internacionais (ALCARAZ; THIRUVATTAL, 2010). Como iniciativa global, o propósito é apresentar valores e orientações de forma estruturada para se constituírem em referências para a transformação da gestão educacional (GODEMANN et al., 2014). Essas referências são apresentadas como princípios, os quais se constituem em conceitos, com as seguintes definições (PRME, 2014):

- Princípio $\mathrm{n}^{\circ} 1$ - Propósito: é o de desenvolver capacidades nos estudantes para serem futuros difusores dos valores de sustentabilidade envolvendo os negócios e a sociedade em geral, visando à economia global inclusiva e sustentável.

- Princípio $n^{\circ} 2$ - Valores: os valores de responsabilidade social global são incorporados nas atividades acadêmicas e nos currículos, conforme apresentado pelas iniciativas internacionais, como a do United Nation Global Compact.

- Princípio $\mathrm{n}^{\mathrm{o}} 3$ - Método: Serão elaboradas orientações educacionais, materiais, processos e situações que propiciam experiências de aprendizagem efetivas para a formação da liderança responsável.

- Princípio $\mathrm{n}^{\circ} 4$ - Pesquisa: envolvimento com pesquisas teóricas e empíricas que permitam aumentar a compreensão sobre o papel, a dinâmica e o impacto das empresas na criação de valores sustentáveis sobre as dimensões social, ambiental e econômica.

- Princípio no 5 - Parceria: interagir com gestores dos negócios das empresas para obter conhecimento sobre os desafios em cumprir as responsabilidades sociais e ambientais, além de desenvolver approaches para enfrentar esses desafios. 
- Princípio no 6 - Diálogo: facilitar o diálogo e debate entre educadores, estudantes, empresas, governo, consumidores, meios de comunicação, organizações da sociedade civil e outros grupos interessados, sobre as questões críticas relacionadas à responsabilidade social global e sustentabilidade.

Como iniciativa global, o foco são as escolas de negócios, as quais estariam incorporando demandas da sociedade ao formar profissionais ou gestores responsáveis, a corporação cidadã, os líderes responsáveis, as instituições sustentáveis, etc. Em outros termos, os conceitos que representam a nova formação sobre os negócios advêm da aplicação da assimilação, incorporação e aplicação dos seis princípios.

Neste sentido, destaca-se a concepção estruturada dos seis princípios, estendendo-se dos propósitos ao diálogo, com as suas delimitações pelas ações e atividades, na execução de cada um deles. Portanto, assume-se que, qualquer que seja o conceito aplicado, os seis princípios devem estar representados pela sua incorporação e execução. Assim, não é possível atribuir a gestão responsável sem a ocorrência dos seis princípios. Ela não se institui pela incorporação e implementação de apenas um deles, como o propósito, ou o diálogo, por exemplo.

Sob esta diretriz, para as escolas em termos do quadro de referência e das orientações sobre a sua implementação, as escolas de negócios passam a ser signatárias do PRME. Como signatárias, há a expectativa de constituir a rede global de instituições, visando à promoção da sustentabilidade e responsabilidade social corporativa. Se, por um lado, há a expectativa de institucionalização de valores universais, por outro, a participação das escolas nesse processo é voluntária, sendo a intensidade desta participação caracterizada pela realização de iniciativas e atividades que são apresentadas nos relatórios bianuais, embora haja o estímulo para que a comunicação ocorra anualmente. Para aprimorar este sistema e visando a integração das interações e comunicações na rede internacional de sustentabilidade, um sistema de indicadores de responsabilidade social universitário foi definido com o propósito de monitorar os resultados alcançados pelas instituições signatárias (PACTO GLOBAL-RED COLOMBIA, 2018).

Importante destacar aqui que esta iniciativa de criar indicadores coletivos na rede PRME é bastante recente (PACTO GLOBAL-RED COLOMBIA, 2018) e pode acelerar a 
implementação das iniciativas PRME nas escolas signatárias. Entretanto, os efeitos da criação desses indicadores ainda não podem ser verificados na presente pesquisa.

A despeito de as áreas e indicadores apresentarem orientações para a elaboração dos relatórios, o desempenho da instituição, pela avaliação da Responsabilidade Social Universitária, é avaliado por componentes, como áreas, que se dividem em aspectos gerais, sub aspectos, e estes, com os seus respectivos indicadores. Assumindo que os parâmetros se constituam em referências para análise da organização e estrutura nas instituições de ensino, o guia identifica a implementação do modelo PRME pelas instituições acadêmicas, como voluntárias, e não pelas iniciativas da Organização das Nações Unidas (ONU) direcionadas à gestão das instituições e escolas de negócios. Se há a constatação entre a diferença entre o "falar" e o "fazer" das escolas de negócios (RASCHE; GILBERT, 2015), o mesmo raciocínio se aplica à ONU sobre a implementação do modelo transformacional do PRME.

Deve-se destacar que, no ano 2016, houve um estreitamento entre as diretrizes do PRME com os Objetivos do Desenvolvimento Sustentável (ODS), possibilitando assim uma aproximação das demais agências das Nações Unidas envolvidas com a questão de sustentabilidade e a sua implementação. De forma abrangente, em setembro de 2015, os membros da ONU adotaram uma agenda de desenvolvimento ampla, com o objetivo de assegurar um futuro melhor para as populações. Assim, foi estabelecido um plano para os próximos quinze anos para acabar com a pobreza extrema, combater a desigualdade, a injustiça e proteger o planeta, plano este denominado de Agenda 2030. A Agenda 2030 se baseia em dezessete objetivos de desenvolvimento sustentável e cento e sessenta e nove metas relacionadas que abordam as questões econômicas, sociais, ambientais e de governança (ONU BRASIL, 2017).

Após o $6^{\circ}$ Fórum Global para Educação Executiva Responsável, realizado também em 2015, fica estabelecido que a iniciativa PRME tem uma posição única como o elo entre a ONU, as empresas participantes do Pacto Global e as instituições de ensino superior, como "comunicador" dos objetivos do desenvolvimento sustentável, além de se constituir em ponte para catalisar a colaboração dos envolvidos (PRME, 2016).

O que se destaca é que, no âmbito da esfera institucional internacional, o conjunto de proposições conceituais é vasto e vago nas intervenções, o que passa a requerer articulações estratégicas visando à sua implementação. Por exemplo, ao modelo PRME são agregadas outras proposições sobre os objetivos do desenvolvimento sustentável, e se assume que, com 
o suporte das Nações Unidas, as universidades signatárias do PRME obtêm reconhecimento internacional e a possibilidade de participar do sistema global de aprendizagem, envolvendo instituições como UNSECO, UNEP, UNDESA, UN Women, UNU, e AcademicImpact ${ }^{4}$. Em outros termos, há uma orientação para o reconhecimento internacional das universidades pela incorporação da gestão sustentável e pela extensão da incorporação do novo modelo, onde a sustentabilidade se constitui na referência para as demais áreas de gestão, dos negócios, na socialização dos segmentos sociais e a consolidação do aparato legal.

Portanto, o conceito de sustentabilidade é componente relevante para a incorporação do modelo PRME e dos ODS. Sob esta pressuposição, a revisão de literatura apresentada abordou as diferentes tendências interpretativas ao conceito de sustentabilidade, mas destacando que, em função do modelo PRME, ele passa ser empregado na dimensão da gestão educacional, diferentemente das iniciativas sobre as concepções orientadoras das intervenções para a conservação e preservação de recursos, da educação ambiental, da formação de docentes e da formação de líderes responsáveis.

Com a finalidade de delimitar os componentes do PRME que são referências para esta investigação, o Quadro 5 apresenta o quadro de referência conceitual identificado pelos autores, os quais sejam: os princípios, pelos objetivos e estratégias, a ênfase sobre a educação responsável e a relevância da gestão da educação responsável.

Quadro 5 - Síntese das definições discutidas -Iniciativa PRME

\begin{tabular}{|l|l|l|}
\hline \multicolumn{1}{|c|}{ Problema Investigado } & \multicolumn{1}{|c|}{ Proposições } & \multicolumn{1}{|c|}{ Autor(es) } \\
\hline Princípios & $\begin{array}{l}\text { Seis princípios como referências para } \\
\text { a gestão educacional responsável. }\end{array}$ & PRME \\
\hline Gestão da educação responsável & $\begin{array}{l}\text { Associa educação em administração } \\
\text { aos valores internacionais. Redefine a } \\
\text { educação para a administração e a } \\
\text { gestão do futuro por meio do PRME. }\end{array}$ & Alcaraz; Thiruvattal (2010) \\
\hline Gestão da educação responsável & $\begin{array}{l}\text { PRME se constitui em referência para } \\
\text { a transformação da gestão } \\
\text { educacional, visando a corporação } \\
\text { cidadã, a corporação comann et al. (2014) } \\
\text { responsabilidade social } \\
\text { sustentabilidade ambiental. }\end{array}$ & \\
\hline Papel das escolas de negócio & Diferença entre o “falar" e o “fazer”. & Rasche; Gilbert (2015) \\
\hline Indicadores de & $\begin{array}{l}\text { Sistema de indicadores de } \\
\text { responsabilidade social universitária. }\end{array}$ & $\begin{array}{l}\text { Pacto Global-Red Colombia } \\
\text { Responsabilidade Social }\end{array}$ \\
\hline
\end{tabular}

Fonte: Elaborado pela autora

\footnotetext{
${ }^{4}$ Disponível em:www.unglobalcompact.org/GettingStartedAcademic/prme.html. Acesso em 10/09/2014.
} 
A síntese das definições apresentadas no Quadro 5 reforçam a proposição do PRME como quadro de referência para a gestão educacional responsável, ao mesmo tempo em que realça a relutância da incorporação das práticas pelas escolas signatárias do PRME. Assim sendo, há duas constatações relevantes para a pesquisa aqui desenvolvida. Uma delas é a existência de um quadro de referência abrangente, que requer operacionalização pelo conceito de identidade sustentável da escola e, a outra, é a ênfase das investigações sobre questões associadas à incorporação deste quadro de referência, o que direciona esta proposta de pesquisa a uma etapa anterior a incorporação, que é a sua compreensãoo pelas escolas signatárias. O item seguinte define o conceito de identidade sustentável da escola e apresenta a sua relevância para o estudo da compreensão do PRME como modelo de gestão educacional.

\subsection{Identidade Sustentável da Escola}

O conceito de identidade sustentável da escola é um dos módulos componentes do modelo de gestão educacional, proposto pelo o Assessment Instrument for Sustainability in Higher Education (AISHE). Os demais módulos são os seguintes: as operações, a educação, a pesquisa e a sociedade, sendo todos definidos por critérios (ROORDA et al., 2009). Não obstante o conjunto dos cinco módulos - considerando o problema investigado, componentes da gestão educacional responsável - a ênfase será sobre um deles, qual seja, o de identidade.

A identidade sustentável é um termo definido por critérios, sem a preocupação com a sua denominação por significados. Assim, há seis critérios sustentáveis da escola, quais sejam a transparência e a prestação de contas, a coerência, o conhecimento, a comunicação, a liderança e a visão e política. Além disso, cada critério é avaliado por estágios, variando de 1 a 5, considerando que esta variação é coerente com as características de cada critério. Por exemplo, enquanto o estágio 1 , no critério transparência, refere-se à disponibilidade de dados quando requeridos, o estágio 1 da coerência se refere à interação entre os membros da instituição.

Sem entrar em detalhes sobre os demais critérios e os referidos estágios, a relevância da referência conceitual está em demonstrar que os critérios e os estágios sobre a identidade sustentável da escola operacionalizam o modelo PRME. Isto é, enquanto o modelo PRME apresenta princípios norteadores sobre a gestão educacional responsável, os critérios associam atributos a eles, e os estágios identificam a extensão das ocorrências. 
O propósito do PRME, princípio 1, de formar o ser humano integral, líder e agente transformador, é consequência do envolvimento institucional com os critérios de transparência, coerência, conhecimento, comunicação, liderança e visão e política. Como conceito, a mesma tendência se aplica aos valores, princípio 2, e ao diálogo, princípio 6. Eles estão presentes em todos os critérios. Por sua vez, a metodologia, a pesquisa e as parcerias são atividades implícitas aos critérios de conhecimento, comunicação e liderança.

Deste conjunto de critérios associados ao modelo PRME, é possível, pela identificação dos estágios em que ocorre, verificar o nível de incorporação desta orientação transformadora sobre as escolas de negócios. A princípio, pode-se supor que a identidade sustentável da escola se desenvolve tanto no ambiente interno quanto no externo a ela, e que esta tendência permite alcançar a liderança responsável. É uma proposição não somente derivada da análise integrada dos critérios, mas que é corroborada pela colocação da liderança e estratégia como área centralizada, no quadro do sistema de indicadores que avaliam as funções relevantes das instituições (PACTO GLOBAL-RED COLOMBIA, 2018).

O Quadro 6 apresenta o quadro de referência conceitual sobre a gestão da educação responsável.

Quadro 6 - Síntese das definições discutidas - Identidade Sustentável

\begin{tabular}{|l|l|l|}
\hline \multicolumn{1}{|c|}{ Problema Investigado } & \multicolumn{1}{|c|}{ Proposições } & \multicolumn{1}{c|}{ Autor(es) } \\
\hline Identidade Sustentável & $\begin{array}{l}\text { Critérios estágios que representam a } \\
\text { identidade sustentável das escolas. } \\
\text { (AISHE) }\end{array}$ & Roorda et al. (2009) \\
\hline $\begin{array}{l}\text { Indicadores de } \\
\text { Responsabilidade Social }\end{array}$ & $\begin{array}{l}\text { Sistema de indicadores de } \\
\text { responsabilidade social universitária. }\end{array}$ & $\begin{array}{l}\text { Pacto Global-Red Colombia } \\
\text { (2018) }\end{array}$ \\
\hline
\end{tabular}

Fonte: Elaborado pela autora

É interessante destacar que o conceito de identidade sustentável da escola se refere, como o PRME, à gestão das instituições de ensino. Portanto, ao comparar os conteúdos dos conceitos sobre a gestão educacional com os empregados sob os contextos de desenvolvimento sustentável, formação de profissionais e de lideranças, nota-se as diferenças de significados e de propósitos.

Apenas para ilustração, valores relacionados à ética, transparência, responsabilidade social, parcerias, diálogos, etc., podem ser comuns às abordagens, mas a gestão educacional os emprega para designar orientações e práticas de gestão da instituição. Por exemplo, ética está em relação aos propósitos da pesquisa e a transparência na apresentação dos relatórios ao 
ambiente externo e aos membros da pesquisa, estudantes e funcionários. Os documentos são disponibilizados e com circulação extensiva.

Como consequência da aplicação de termos iguais com significados diferentes, podese emprega-los, inclusive, para diferenciar os propósitos da gestão educacional daqueles da educação executiva. Enquanto a primeira enfatiza a capacidade de análise crítica sobre o processo educacional em termos dos aspectos administrativos, financeiros, políticos, pedagógicos, culturais e sociais ${ }^{5}$, a segunda desenvolve habilidades para os negócios, aprimora a capacidade de gerenciamento, inova as atividades da organização, procura resultados a curto prazo, investindo atualmente nas tecnologias digitais ${ }^{6}$. Pode-se acrescentar que a gestão responsável é a transformação da gestão educacional visando a corporação cidadã, envolvida pela responsabilidade social e sustentabilidade ambiental (GOLEMANN et al., 2014).

Além disso, os critérios de identidade sustentável, segundo o modelo de gestão proposto pelo AISHE (Roorda et al., 2009), pode ser associado aos princípios da gestão educacional responsável, proposto pelo PRME. Dessa forma, pode-se considerar que a identidade sustentável da escola pode ser gerada por meio do PRME, uma vez que, os critérios da identidade sustentável estão implícitos nos princípios da gestão responsável. O Quadro 7 apresenta a relação entre os princípios do PRME e os critérios de identidade sustentável do AISHE.

Quadro 7 - Matriz amarração entre PRME e módulo identidade AISHE

\begin{tabular}{|c|c|c|c|c|c|c|}
\hline PRME & Propósito & Valores & Método & Pesquisa & Parceria & Diálogo \\
\hline TrSHE & & & & & & $\mathrm{X}$ \\
\hline Coerência & $\mathrm{X}$ & $\mathrm{X}$ & & & & $\mathrm{X}$ \\
\hline Conhecimento & $\mathrm{X}$ & $\mathrm{X}$ & $\mathrm{X}$ & $\mathrm{X}$ & $\mathrm{X}$ & $\mathrm{X}$ \\
\hline Comunicação & $\mathrm{X}$ & $\mathrm{X}$ & $\mathrm{X}$ & $\mathrm{X}$ & $\mathrm{X}$ & $\mathrm{X}$ \\
\hline Liderança & $\mathrm{X}$ & $\mathrm{X}$ & $\mathrm{X}$ & $\mathrm{X}$ & $\mathrm{X}$ & $\mathrm{X}$ \\
\hline
\end{tabular}

\footnotetext{
${ }^{5}$ Disponível em: http://www.faculdadesdaindustria.org.br/pos-graduacao/especializacao-em-gestao-educacional. Acesso em 16/04/2019.

${ }^{6}$ Disponível em: http://www.parceirosvoluntarios.org.br/. Acesso em 16/04/2019.
} 


\begin{tabular}{|c|c|c|c|c|c|c|}
\hline $\begin{array}{c}\text { Visão e } \\
\text { Política }\end{array}$ & $\mathrm{X}$ & $\mathrm{X}$ & & & $\mathrm{X}$ \\
\hline
\end{tabular}

Fonte: Elaborado pela autora

A partir do Quadro 7, pode-se observar que os princípios 1, 2 e 6, propósito, valores e diálogo, respectivamente, apresentam envolvimento institucional com todos os critérios de identidade sustentável. Enquanto que os princípios 3, 4 e 5, método, pesquisa e parceria, respectivamente, são atividades implícitas aos critérios de conhecimento, comunicação e liderança. 


\section{MÉTODO}

Esta investigação emprega os fundamentos da técnica de triangulação, a qual envolve a combinação de metodologias qualitativas e quantitativas, visando à análise e interpretação do objeto em estudo. Segundo Marconi e Lakatos (2017, p. 285) “a triangulação tem por objetivo abranger a máxima amplitude na descrição, explicação e compreensão do fato estudado", o que requer diferentes fontes de dados e de informações, caracterizando-se pelo emprego de múltiplos meios.

Considerando que a triangulação associa o seu emprego à pesquisa descritiva, este propósito de investigação possui a finalidade de descrever fatos, situações, eventos, intervenções, etc., assegurada pela forma lógica, precisa e quantitativa, quando da operacionalização para representar as manifestações dos fatos. Nesta associação entre tipos de pesquisas, admite-se que "a pesquisa qualitativa preocupa-se em analisar e interpretar aspectos mais profundos, descrevendo a complexidade do comportamento humano. Fornece análises mais detalhadas sobre investigações, atitudes e etc" (MARCONI; LAKATOS, 2017, p.270). Por outro lado, “o método quantitativo representa a intenção de garantir a precisão dos resultados, evitar distorções de análise e interpretação, possibilitando, consequentemente, uma margem de segurança quanto às inferências" (RICHARDSON, 2017, p. 70).

A despeito da relevância dessas técnicas, elas não são suficientes para a justificativa das análises, pois este instrumental requer a sua associação com os conceitos orientadores, definidos pela revisão de literatura. Como apresentado no capítulo anterior, esses conceitos permitem a operacionalização dos dados em escalas ordinais e nominais, as quais fundamentam a construção de gráficos, quadros e tabelas para a exposição dos resultados e para fundamentar as inferências apresentadas na conclusão. Graficamente, este delineamento conceitual e operacional da pesquisa é ilustrado pela Figura 1. 
Figura 1 - Delineamento da pesquisa

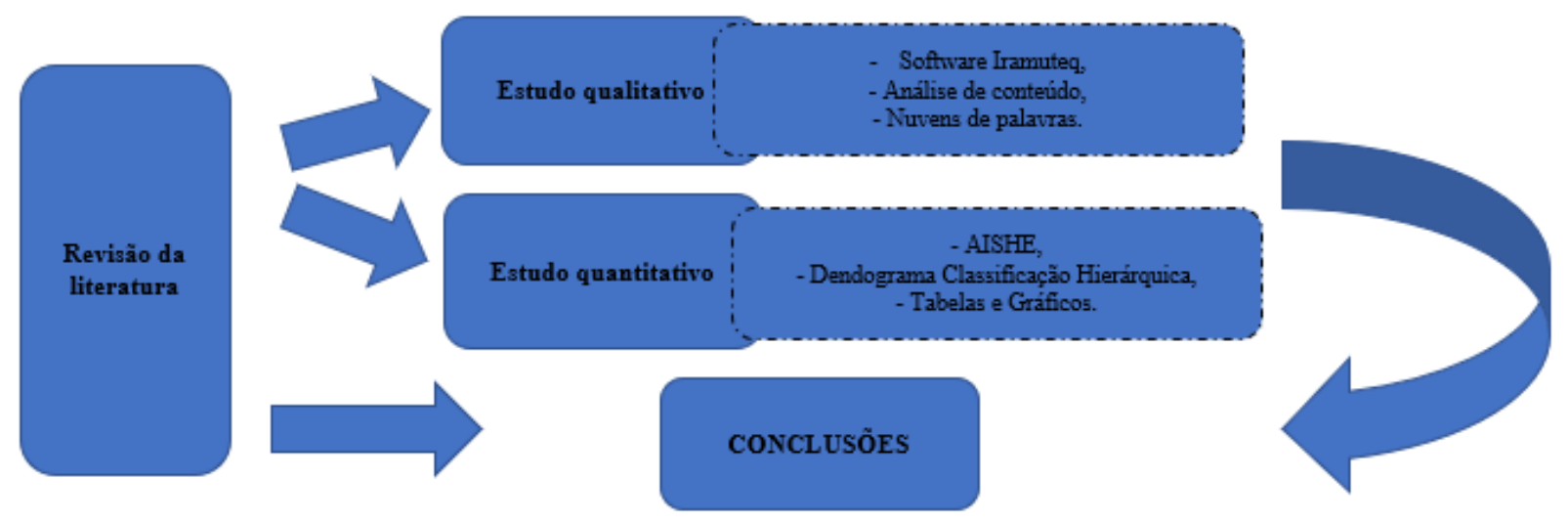

Fonte: Elaborada pela autora

Deve-se explicitar que, como figura ilustrativa do delineamento da pesquisa, as técnicas empregadas, como o Iramuteq e o AISHE, serão descritos após a apresentação dos procedimentos empregados na descrição da população e dos procedimentos empregados para a seleção das unidades amostrais.

\subsection{População e Amostra}

A população de escolas signatárias do PRME, na realização desta pesquisa, conforme apresentada no Quadro 8, era de 24 escolas no ano de realização da primeira fase desta pesquisa (2016), identificada a partir do ano de postagem do SIP (2014 ou 2015). O SIP é um documento periódico, postado bienalmente e que relata as ações realizadas pelas instituições signatárias do PRME (PRME BRAZIL, 2016).

Quadro 8 - Relação das Instituições, por Estados, signatárias do PRME no Brasil

\begin{tabular}{|l|l|}
\hline \multicolumn{1}{|c|}{ ESCOLA DE NEGÓCIO } & \multicolumn{1}{c|}{ ESTADO } \\
\hline Antônio Meneghetti Faculdade & Rio Grande do Sul \\
\hline $\begin{array}{l}\text { Escola Brasileira de Administração Pública e de } \\
\text { Empresas (EBAPE/FGV) }\end{array}$ & Rio de Janeiro \\
\hline $\begin{array}{l}\text { Escola de Administração de Empresas de São Paulo } \\
\text { (EAESP/FGV) }\end{array}$ & São Paulo \\
\hline Escola Superior de Propaganda e Marketing (ESPM) & Rio Grande do Sul \\
\hline Estação Business School & Paraná \\
\hline $\begin{array}{l}\text { Faculdade de Economia, Administração e } \\
\text { Contabilidade - USP }\end{array}$ & São Paulo \\
\hline Faculdades Integradas do Brasil (UniBrasil) & Paraná \\
\hline FEA-RP/USP & São Paulo \\
\hline FIA - Fundação Instituto de Administração & São Paulo \\
\hline Fundação Dom Cabral (FDC) & Minas Gerais \\
\hline
\end{tabular}




\begin{tabular}{|l|l|}
\hline IAG - Business School (PUC) & Rio de Janeiro \\
\hline Insper & São Paulo \\
\hline Instituto de Tecnologia do Paraná - TECPAR & Paraná \\
\hline ISAE/FGV & Paraná \\
\hline SENAI & Paraná \\
\hline OPET - Organização Paranaense de Ensino Técnico & Paraná \\
\hline $\begin{array}{l}\text { Pontifícia Universidade Católica de São Paulo- } \\
\text { PUCSP }\end{array}$ & São Paulo \\
\hline SECAL & Paraná \\
\hline SESI & Paraná \\
\hline $\begin{array}{l}\text { União Paranaense de Ensino e Cultura (UNIPEC) } \\
\text { Faculdades Integradas Santa Cruz }\end{array}$ & Paraná \\
\hline UniCESUMAR & Paraná \\
\hline Universidade COPEL - UniCOPEL & Paraná \\
\hline Universidade Metodista de São Paulo & São Paulo \\
\hline Universidade Tecnologia Federal do Paraná & Paraná \\
\hline
\end{tabular}

Fonte: Elaborado pela autora

Do total de instituições, 12 delas estão no Estado do Paraná, 7 no Estado de São Paulo, 2 no Estado do Rio Grande do Sul, 2 no Estado do Rio de Janeiro e 1 no Estado de Minas Gerais. Considerando as localizações geográficas das escolas, o tempo na rede PRME, a oferta do curso na formação dos profissionais e o nível de excelência, segundo o Ranking Universitário Folha, 2018 (RUF), das 7 escolas identificadas no Estado de São Paulo, 2 foram selecionadas para comporem a amostra. Nota-se que a seleção se dá por critérios de relevância, sendo selecionada uma escola pública, signatária do PRME desde 2012, e outra escola privada, signatária do PRME desde 2016. Assim, 30\% da população das escolas PRME do Estado de São Paulo está sendo considerada neste estudo.

Não obstante, sob o propósito de melhor compreender a formação do conhecimento em sustentabilidade nas escolas signatárias selecionadas, adotou-se a estratégia comparativa, o que gerou a necessidade de identificar duas escolas de negócios não signatárias do PRME, sendo uma pública e a outra privada. O critério adotado neste processo foi de semelhança, em relação às características que determinaram a seleção das escolas de negócios signatárias do PRME, ou seja, a região geográfica, os cursos oferecidos, a excelência e o público-alvo. Desta forma, este estudo envolveu quatro escolas, sendo duas públicas e duas privadas, signatárias e não signatárias do PRME, conforme ilustrado no Quadro 9, a seguir:

Quadro 9 - Classificação das Escolas selecionadas

\begin{tabular}{|c|c|}
\hline Escola PRME-Pública & Escola PRME-Privada \\
Escola de negócios pública, signatária do & Escola de negócios privada, signatária do \\
\hline
\end{tabular}




\begin{tabular}{|c|c|}
\hline PRME & PRME \\
\hline Escola Não PRME- Pública & Escola Não PRME-Privada \\
Escola de negócios pública, não-signatária do & Escola de negócios privada, não-signatária do \\
PRME & PRME \\
\hline
\end{tabular}

Fonte: Elaborado pela autora

Para fins desta investigação, as escolas foram assim denominadas: as escolas signatárias do PRME são identificadas como "PRME-Pública" e "PRME-Privada", respectivamente, e as escolas não signatárias do PRME como "Não PRME-Pública" e "Não PRME-Privada", respectivamente. Deste modo, pode-se assegurar o sigilo sobre as escolas de negócios e os respectivos respondentes.

Enquanto as escolas se constituem na primeira unidade amostral, é a partir delas que são identificadas as demais unidades investigadas neste estudo, quais sejam, os docentes e os formandos dos referidos cursos. Como não havia a delimitação da população dos docentes e dos discentes, a participação dos mesmos ocorreu em função das disponibilidades e interesses deles em participarem da pesquisa. Em função da ausência desses dados, o método de amostragem empregado é a amostra não probabilística. Este método é caracterizado por apresentar diferentes alternativas, em função das características da população investigada, especialmente as associadas à ausência de dados e informações.

Entre os procedimentos não probabilísticos, como a amostra por conveniência, por quotas, por bola de neve e por experts (UPRICHARD, 2013), o aplicado nesta investigação foi o de conveniência. Este método implica em selecionar de uma população, empiricamente definida como docentes e formandos do curso de administração, que apresenta disponibilidade em responder ao questionário.

Como não há segurança sobre esta disponibilidade, a conveniência é definida pelo critério de disponibilidade e pelo fácil acesso aos respondentes e não pela propensão dos respondentes em apresentarem dados e informações que irão justificar a questão da pesquisa investigada (UPRICHARD, 2013). É evidente que este processo amostral possui restrições, por isso as análises se restringem ao conjunto de questionários que retornaram após o encaminhamento. 


\subsection{Coleta de Dados}

O processo de coleta de dados se constituiu de várias etapas. Inicialmente, foram realizados os contatos com os Coordenadores do curso de Administração, no nível de graduação, das escolas de negócios selecionadas, explicando os objetivos e a relevância da pesquisa. Após o contato inicial, foram realizadas duas etapas: a primeira foi a de solicitar o Projeto Pedagógico do Curso (PPC), especificamente para aquelas escolas em que o PPC não estava disponível no respectivo site, e a segunda foi a de aplicar o questionário AISHE 2.0, versão $\mathrm{D}$, tanto aos formandos quanto aos docentes do curso de Administração.

Os procedimentos para a coleta dos dados decorrem dos objetivos específicos. Esses objetivos requerem dados sobre as escolas e sobre os docentes e discentes das escolas selecionadas. Em relação às escolas, os dados para analisar os valores de sustentabilidade incorporados nas ementas das disciplinas, assim como a identificação das metodologias incorporadas nas atividades acadêmicas e nos currículos das escolas são provenientes do Projeto Político Pedagógico do Curso (PPC) das escolas, signatárias e não signatárias do PRME.

Em relação aos PPCs, o objetivo foi o de identificar a natureza dos vocábulos nos textos e a frequência de ocorrência dos mesmos para identificar a introdução de termos que expressam o conhecimento em sustentabilidade do curso. Esses dados se constituíram em referências para suportar as análises dos dados gerados pelo instrumento AISHE.

O instrumento AISHE foi aplicado in loco aos formandos dos cursos. Para tanto, dias e horários foram disponibilizados e definidos pelo Coordenador do curso. Aos docentes, foi enviado o link do AISHE por meio do formulário do Google. A Tabela 1 apresenta o total de questionários encaminhados aos docentes, a quantidade de retorno, a identificação da taxa de retorno e o número de questionários aplicados aos discentes, nas escolas de negócios signatárias e não signatárias, bem como a natureza pública e privada das escolas de negócios.

Tabela 1 - Questionários aplicados ao público alvo e taxas de retorno

\begin{tabular}{l|l|c|c|c|c|c|c}
\hline $\begin{array}{c}\text { Tipos de } \\
\text { Escolas }\end{array}$ & $\begin{array}{c}\text { Escolas de } \\
\text { Negócios }\end{array}$ & $\begin{array}{c}\text { AISHE } \\
\text { Encaminhados } \\
\text { Docentes }\end{array}$ & $\begin{array}{c}\text { Retorno } \\
\text { AISHE } \\
\text { Docente }\end{array}$ & $\begin{array}{c}\text { Taxa de } \\
\text { Retorno } \\
\%\end{array}$ & $\begin{array}{c}\text { Número de } \\
\text { formandos } \\
\text { nas escolas }\end{array}$ & $\begin{array}{c}\text { AISHE } \\
\text { Aplicado } \\
\text { Discentes }\end{array}$ & $\begin{array}{c}\text { Taxa de } \\
\text { Retorno } \\
\%\end{array}$ \\
\hline Pública & PRME & 37 & 19 & 51 & 21 & 11 & 52 \\
\hline Privada & PRME & 52 & 12 & 23 & 35 & 27 & 77 \\
\hline Pública & Não PRME & 11 & 8 & 73 & 26 & 12 & 46 \\
\hline Privada & Não PRME & 13 & 11 & 85 & 32 & 23 & 71 \\
\hline \multicolumn{2}{l}{ Total } & 113 & 50 & 44 & 114 & 73 & 64 \\
\hline
\end{tabular}


De acordo com Tabela 1, destaca-se a taxa de retorno dos questionários encaminhados aos docentes das escolas investigadas que foi de $44 \%$.

Neste processo, deve-se destacar, encaminhou-se um e-mail sobre a investigação e da relevância do docente em fornecer as informações requeridas. Como é de praxe, nem sempre ocorrem as devoluções e para que isto ocorresse, foram necessárias várias comunicações com os docentes com o objetivo de estimulá-los a responder o questionário. É a fase de monitoramento dos retornos, onde a atividade básica é manter a comunicação com os docentes, visando à obtenção da taxa máxima de retorno, em função do tempo disponível pela espera. Como consequência, identificou-se uma taxa de retorno significativa, especialmente pelo fato de a amostra em questão não ser probabilística ${ }^{7}$.

Outro aspecto a destacar na Tabela 1 é que, apesar de o maior número de docentes situar-se nas escolas signatárias do PRME, pública e privada, encontrou-se nelas a menor taxa de retorno dos questionários, $51 \%$ e $23 \%$. Comparativamente, nas escolas de negócios pública e privada, não signatárias do PRME, as taxas de retorno foram maiores, $73 \%$ e 85\%, respectivamente. Teoricamente, esta indisponibilidade em não responder ao questionário, por parte das escolas signatárias, contradiz o princípio no. 6 do PRME, que é o diálogo, isto é, a participação com outros grupos interessados sobre as questões relacionadas à sustentabilidade, especificamente.

\subsection{Instrumentos de Análises dos Dados}

As análises do PPC foram feitas por meio de análise de conteúdo, utilizando-se o software Iramuteq ${ }^{8}$. Este software descreve os textos e os segmentos dos textos nos PPCs, além de permitir comparações entre eles pelas ocorrências das palavras que eles empregam. Assim, uma das análises empregadas é a nuvem de palavras, visando a organização das palavras em função de sua frequência, sendo que a outra é a Classificação Hierárquica Descendente (CHD), que identifica vocábulos nos textos que são semelhantes entre si, e diferentes entre as classes. Esta classificação é representada por um dendograma (CAMARGO; JUSTO, 2013). Deste modo, a nuvem de palavras e a CDH se complementam, na representação dos vocábulos dos PCCs entre as escolas, com o propósito de evidenciarem

\footnotetext{
${ }^{7}$ Pode-se destacar que, para alguns autores, a taxa de retorno acima de $30 \%$ é suficiente para a realização da pesquisa descritiva e a identificação de tendências nos dados.

${ }^{8}$ O IRAMUTEQ é um software gratuito e com fonte aberta, desenvolvido por Pierre Ratinaud que permite fazer análises estatísticas sobre corpus textuais e sobre tabelas indivíduos/palavras.
} 
o emprego de vocábulos semelhantes e diferentes daqueles empregados nos conceitos de identidade sustentável da escola e do modelo PRME.

Outro instrumento de análise foi o Assessment Instrument for Sustainability in Higher Education (AISHE 2.09 ). Por ser um instrumento concebido, operacionalizado e aplicado no idioma inglês, desenvolvido pelo holandês Niko Roorda, foi necessário realizar a sua tradução e a validação para o idioma português. Para tanto, o processo de validação iniciou-se com a autorização do autor, seguido pelas etapas metodológicas de acordo com Nogueira (2012).

A primeira etapa constituiu-se na tradução do instrumento original do inglês para o português, resultando na versão A. Essa tradução foi realizada por um grupo de pesquisadores (indivíduos A), conhecedores do tema sustentabilidade e da língua inglesa. Após essa tradução, a versão A foi submetida a um pré-teste para análise de 17 especialistas com o objetivo de adequar o instrumento e seus termos à realidade das escolas de ensino superior brasileiras, portanto, resultando, na versão B.

O segundo passo consistiu na tradução reversa. Dessa forma, a versão B foi traduzida para o inglês. Essa tradução foi realizada por um tradutor profissional britânico, conhecedor da língua portuguesa, que não teve acesso à versão original. A tradução reversa resultou na versão C, que foi enviada ao autor para confrontar com a versão original, como forma de validação. A terceira etapa consistiu na adaptação do instrumento, adequando os conflitos entre as traduções, envolvendo os indivíduos A e o autor do instrumento original, resultando na versão final $\mathrm{D}$, disponível no Anexo A.

Conceitualmente, o instrumento AISHE está estruturado de forma modular, composto pelos módulos seguintes: operações, educação, pesquisa, sociedade e identidade. Cada módulo é subdividido em critérios, conforme apresentado pelo Quadro 10, com o propósito de avaliar a gestão educacional das instituições de ensino, por cada um deles, ou pelo conjunto de critérios.

\footnotetext{
${ }^{9}$ A versão 2.0 do Assessment Instrument for Sustainability in Higher Education (AISHE) surgiu em 2009.
} 
Quadro 10 - Módulos conceituais do AISHE 2.0

\begin{tabular}{|c|c|c|c|}
\hline \multicolumn{4}{|c|}{ AISHE 2.0} \\
\hline Operaçōes & Educação & Pesquisa & Sociedade \\
\hline Avaliação da qualidade & Avaliação final & Avaliação final & Impacto da avaliação \\
\hline Humanidade & Integração interdisciplinar & Integração interdisciplinar & Conexão \\
\hline Ecologia & Integração temática & Integração temática & Envolvimento temático \\
\hline Economia & Noções básicas de sensibilização & Noções básicas de sensibilização & Sensibilização e aprendizagem \\
\hline Estrutura Física & Metodoloia & Metodologia & Metodologia \\
\hline Metas & Metas & Metas & Metas \\
\hline \multicolumn{4}{|c|}{ Identidade } \\
\hline & Transparênci & $\begin{array}{l}\text { ação de contas } \\
\text { ia } \\
\text { ento } \\
\text { ção } \\
\text { a } \\
\text { lítica }\end{array}$ & \\
\hline
\end{tabular}

Fonte: Adaptado pela autora de Roorda et al. (2009)

Para fins desta investigação, o módulo em estudo é o de identidade, que expressa um conjunto de critérios e que apresenta o desenvolvimento da sustentabilidade por meio de estágios. Assim sendo, os critérios do referido módulo são seis, quais sejam: "visão e política", "liderança", "comunicação", "conhecimento", "coerência” e "transparência.

Enquanto os critérios são dimensões conceituais do módulo "identidade" da escola, a avaliação de cada um deles se dá em termos de estágios. Assim, cada critério é avaliado por estágios que variam de um a cinco. Diferentemente das avaliações usuais sobre a ocorrência dos fatores, onde 1 revela a não ocorrência e o 5 a ocorrência, os estágios de 1 a 5 , no instrumento AISHE, possuem significados conceituais diferentes entre os critérios ${ }^{10}$. O fundamental é que cada critério, pelas avaliações dos docentes e dos discentes nos diferentes estágios, retrata o desenvolvimento das atividades da escola no alcance da sua identidade sustentável.

Em síntese, as etapas empreendidas na delimitação metodológica desta investigação seguem a sequência lógica instituída pelo problema, objetivos da pesquisa e conceitos identificados na revisão de literatura, os quais orientam desde a definição da população até a identificação dos instrumentos de análise dos dados. Há uma sequência que é representada pela Figura 2. Além desta, há, no Quadro 11, a representação de toda sequência lógica a partir dos objetivos.

Deve-se explicitar que esta trajetória é delineada a partir do problema investigado e dos objetivos associados a ele. Por isso, a apresentação do Quadro 11, o qual ilustra a vinculação dos componentes conceituais do problema e objetivos com os pressupostos metodológicos.

\footnotetext{
${ }^{10}$ Os critérios e os significados dos estágios em cada um deles são apresentados no ANEXO A.
} 
Figura 2 - Pressupostos metodológicos da pesquisa

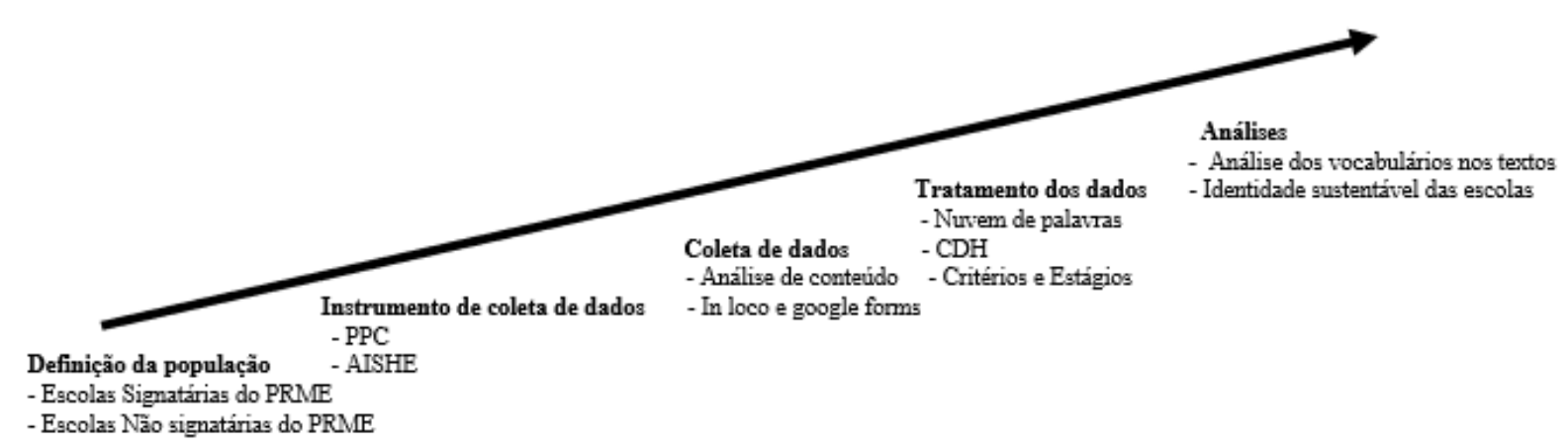

Fonte: Elaborada pela autora 
Quadro 11 - Aspectos metodológicos da pesquisa

\begin{tabular}{|c|c|c|c|c|}
\hline OBJETIVO GERAL & OBJETIVOS ESPECÍFICOS & QUESTÃO PROBLEMA & PROPOSIÇÃO DE TRABALHO & TIPO DE PESQUISA \\
\hline $\begin{array}{l}\text { Identificar o nível da } \\
\text { identidade em relação à } \\
\text { sustentabilidade das escolas } \\
\text { de negócios, brasileiras, } \\
\text { signatárias e não signatárias } \\
\text { do PRME. }\end{array}$ & $\begin{array}{l}\text { 1. Identificar e descrever os critérios e os } \\
\text { estágios apontados pelos docentes e } \\
\text { discentes formandos sobre a identidade } \\
\text { sustentável das escolas. } \\
\text { 2. Identificar e descrever os conteúdos } \\
\text { dos segmentos constantes dos Projetos } \\
\text { Pedagógicos dos Cursos, quais sejam: o } \\
\text { perfil do egresso, o objetivo do curso, as } \\
\text { metodologias de ensino e aprendizagem } \\
\text { adotadas pela escola e as disciplinas } \\
\text { curriculares. } \\
\text { 3. Identificar e descrever as frequências } \\
\text { de ocorrências, similitudes e diferenças } \\
\text { das palavras nos textos dos Projetos } \\
\text { Pedagógicos dos Cursos. } \\
\text { 4. Identificar e descrever as similitudes e } \\
\text { diferenças do resultados envolvendo os } \\
\text { critérios e estágios de identidade } \\
\text { sustentável das escolas pelos docentes e } \\
\text { discentes e das palavras do PPCs e do } \\
\text { PRME. }\end{array}$ & $\begin{array}{l}\text { Quais as percepções dos docentes e } \\
\text { discentes sobre a identidade sustentável } \\
\text { da escola? }\end{array}$ & $\begin{array}{l}\text { H1: Os docentes e discentes das escolas } \\
\text { de negócios, signatárias do PRME, } \\
\text { possuem uma percepção mais } \\
\text { desenvolvida (nível macro) da } \\
\text { identidade sustentável da escola. }\end{array}$ & $\begin{array}{l}\text { Descritiva, qualitativa, por meio } \\
\text { de análise de conteúdo, software } \\
\text { Iramuteq, e questionário do } \\
\text { AISHE. }\end{array}$ \\
\hline
\end{tabular}




\section{RESULTADOS}

A análise dos dados sobre as quatro escolas investigadas, inicia-se pela investigação das duas escolas signatárias do PRME, uma pública e a outra privada, seguida da apresentação dos resultados das duas escolas não signatárias do PRME, uma pública e a outra privada. Há, assim, a análise descritiva e interpretação dos dados para cada uma das escolas, separadamente. Posteriormente, a lógica de análise será comparativa, de modo que a análise inicial compara as duas escolas signatárias do PRME, e, posteriormente, as duas escolas não signatárias, além da comparação entre as escolas signatárias e não signatárias. Assim, o foco da análise recai sobre as unidades de análises, que são os docentes, os discentes e o PPC, identificando divergências e homogeneidades dos conteúdos entre as escolas signatárias e não signatárias.

Deve-se deixar explícito que a proposição inicial é a de que há divergências entre as escolas signatárias e não signatárias sobre os critérios que caracterizam a identidade delas, bem como sobre o desenvolvimento da sustentabilidade, visando o alcance da gestão educacional responsável. Não obstante, esta proposição é melhor apreendida pela extensão da comparação entre a escola pública signatária com a escola pública não signatária e escola privada signatária com a escola privada não signatária. Se houver divergências entre elas, pode-se constatar que as iniciativas do PRME estão ocorrendo, de forma geral, no processo de transformação da gestão educacional. Caso contrário, tendo o PRME como referência para introduzir a identidade sustentável nas escolas, pode-se inferir sobre a complexidade do processo, identificando as possíveis lacunas que devem ser superadas para que aquelas orientações se concretizem.

Enquanto os objetos de análise são as quatro escolas, os instrumentos de geração de dados, para as quatro escolas, são o questionário AISHE e o software Iramuteq, os quais foram descritos anteriormente. Entretanto, é necessário explicitar que o objetivo do AISHE é de identificar, por meio do questionário aplicado aos docentes e discentes, a identidade da escola, sob seis critérios, e a inferência sobre a identidade sustentável da escola, em função das análises sobre a relevância dos estágios nos referidos critérios. O propósito final é caracterizar a ocorrência da identidade sustentável desde o nível micro até o nível macro.

Por sua vez, o software Iramuteq foi o instrumento de análise dos Projetos Pedagógicos dos Cursos (PPC) em cada escola investigada, permitindo a identificação das palavras e a sua frequência de ocorrências. Este procedimento se constitui em referência para 
a análise da associação ou não dessas palavras quanto à identidade sustentável da escola, evidenciada pela análise do questionário AISHE, quanto pela comparação ao PRME.

$\mathrm{Na}$ análise de sustentabilidade, por escola, utilizaram-se as análises da estatística textual e de nuvem de palavras. Complementando essa análise, em função da realização das análises comparativas entre os textos dos PPCs das escolas, empregou-se o método da classificação hierárquica descendente $(\mathrm{CDH})$.

\subsection{Análise da Identidade Sustentável das Escolas}

Este item apresenta as análises dos dados sobre as escolas (pública e privada) signatárias do PRME e das escolas (pública e privada) não signatárias do PRME. As fontes de informações são os docentes e discentes das escolas, e o Projeto Político Pedagógico dos Cursos em questão. Esta análise se desenvolve em dois momentos: primeiro sobre cada escola separadamente e, segundo, comparando os resultados entre as escolas signatárias, entre as não signatárias e entre as escolas signatárias e não signatárias.

\subsubsection{Escola PRME - Pública}

A caraterização da identidade sustentável da escola pública signatária do PRME com base em seis critérios é apresentada no Gráfico 1. Esta discriminação é realizada por 19 docentes do curso de administração, que identificam a ocorrência desses critérios em quatro, dos cinco estágios. Inicialmente, constata-se que os docentes admitem que, para todos os critérios, a escola não assimila o feedback da cadeia de atores da sociedade, visando adequar os seus objetivos, processos e resultados, que é o estágio 5. Portanto, na visão dos docentes participantes da pesquisa, a escola não atinge plenamente a gestão educacional responsável, afastando a escola da incorporação dos valores internacionais na gestão educacional (ALCARAZ; THIRUVATTAL, 2010).

Iniciando com o critério transparência, o Gráfico 1 retrata que a sua maior frequência (63\%) ocorre no estágio 1, evidenciando que há a disponibilidade de informações sobre os processos e resultados, mas que elas estão fornecidas a um grupo limitado de funcionários. Não obstante, as frequências de ocorrências nos estágios 2 e 3, com 16\% em cada um deles, indicam a importância, em menores proporções, da orientação da sustentabilidade da escola para o processo e para o sistema. Isto é, as informações são apresentadas de forma estruturada e os relatórios são anexados ao relatório anual público. 
Deste modo, 95\% das ocorrências demonstram que o critério transparência como critério da identidade sustentável da escola ocorre em nível micro, mas se estende até o intermediário, de forma muito intensa. Sobre o estágio 4, a orientação das atividades de sustentabilidade é pela cadeia, destacando a relevância do feedback para as partes interessadas. Para os docentes participantes da pesquisa, as atividades de retroalimentação, pela frequência de ocorrência muito baixa (5\%), ocorrem de forma quase insignificante, o que é coerente com o percentual de respostas (16\%) dos docentes sobre a disponibilização das informações para o sistema.

Gráfico 1 - Identidade sustentável da escola PRME-Pública para os docentes

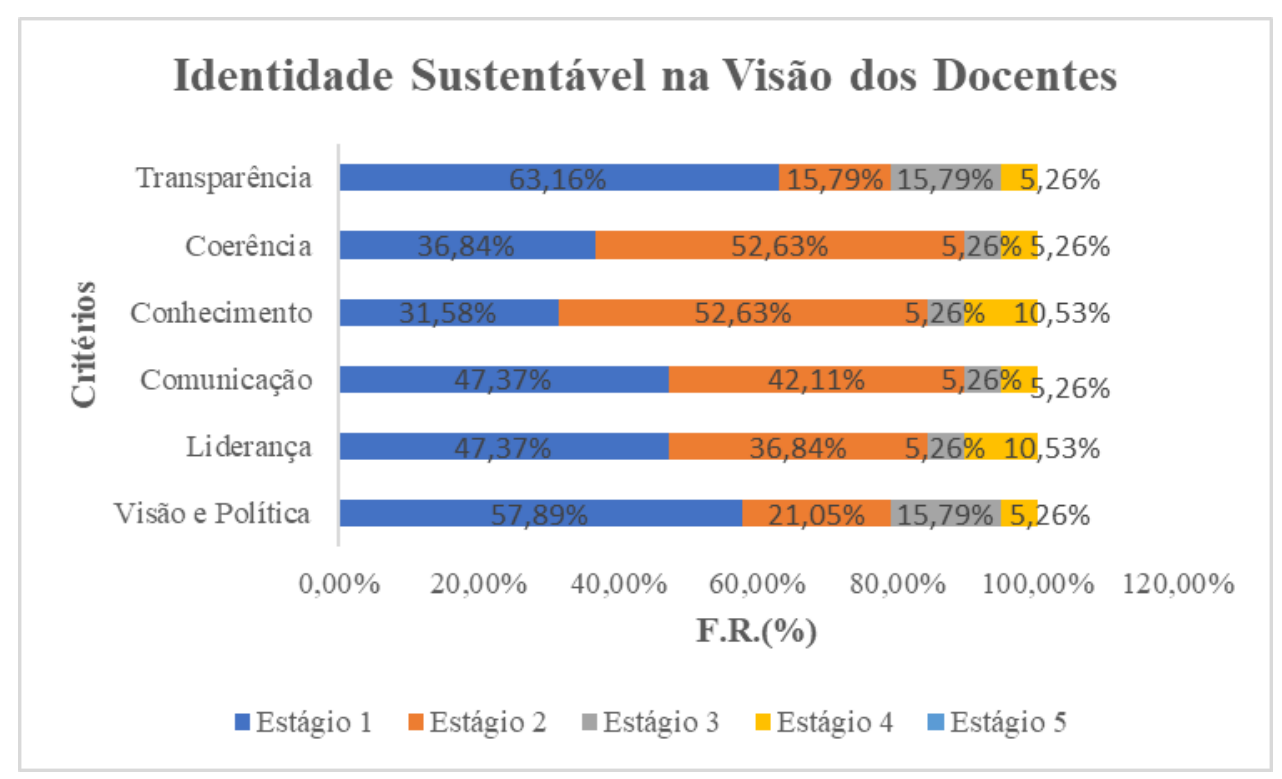

Fonte: Dados da pesquisa

Em relação à coerência como critério de identidade sustentável da escola, que consiste na realização dos papéis de educar, de investigar e de contribuir para a sociedade, a maior frequência de ocorrência está no estágio 2 (52\%). Isto é, a percepção dos docentes participantes da pesquisa é que a escola possui diversas ações relacionadas aos aspectos da sustentabilidade e que, pelos percentuais das respostas no estágio 1 (36\%), essas intervenções ocorrem de forma participativa. Tem-se, portanto, o predomínio dos estágios em níveis micros (88\%) como estágios relevantes, que expressam que a coerência, como critério de identidade sustentável da escola, ocorre de forma parcial. Este fato é também corroborado pelos valores baixos dos percentuais nos estágios 3 e 4, com os valores de 5\%, respectivamente. Em outros 
termos, os diferentes papeis que a escola desempenha, relativos à sua identidade sustentável, não estão fortemente orientados para o sistema interno da escola e nem para a cadeia de atores, no ambiente externo.

A sustentabilidade da escola pelo critério conhecimento é definida pela sua tendência em disponibilizá-lo aos ambientes internos e externos. Pelo Gráfico 1, nota-se que esta disponibilização se destaca pelo percentual de respostas (52\%) no estágio 2, demonstrando que há uma equipe responsável para tanto, além das instalações de infraestrutura necessárias. Sob estas condições identifica-se, pelo percentual de respostas no estágio 1 (31\%), que o conhecimento disponível depende das iniciativas individuais na escola e entre a escola e os contatos com o ambiente externo.

Considerando os dois estágios iniciais, $83 \%$ dos respondentes admitem que a disponibilização dos conhecimentos se concentra no nível micro da escola. Por sua vez, há o destaque sobre o estágio 4 , onde $10 \%$ dos respondentes asseguram que os contatos com o ambiente externo contribuem para o desenvolvimento do conhecimento na instituição. Comparando este resultado com o do estágio 1, pode-se inferir que parte dos docentes envolvidos com a pesquisa e o ensino possui atividades integradas ao ambiente externo.

A percepção da comunicação como critério de identidade sustentável da escola também se concentra no estágio $1(47 \%)$ e no estágio $2(42 \%)$. Considerando que a comunicação disponibiliza informações, esses percentuais revelam que ela é direcionada para os membros da equipe, apresentada regularmente nas pautas das reuniões, em publicações e em apresentações da instituição.

Esta tendência também é encontrada no critério liderança. A identidade da escola é expressa pelo estágio 1 (47\%) e pelo estágio 2 (36\%). Na percepção dos docentes participantes da pesquisa, a liderança está, em relação à equipe e membros da instituição, estendendo-se aos funcionários e aos estudantes. Pelos resultados dos estágios 3 e 4 , a escola não incentiva a liderança o suficiente para a participação no processo, o que atinge de forma muito parcial os stakeholders e os centros de especialização. Portanto a liderança sendo critério que caracteriza a identidade da escola como estratégia para o alcance da gestão educacional responsável está restrita ao ambiente interno a ela.

O último critério de identidade da escola é a visão e política. Este critério expõe, para os ambientes internos e externos a ela, a sua gestão responsável. Ao mesmo tempo em que ela é construída verticalmente, de cima para baixo, conforme $57 \%$ das respostas, ela expressa os 
valores básicos e éticos da instituição apresentados em documentos, de acordo com $21 \%$ dos docentes participantes da pesquisa. Entretanto, sob a percepção da visão e política, $15 \%$ dos respondentes no estágio 3 destacam que ela é orientada para o sistema interno à instituição, não se estendendo de forma efetiva aos stakeholders, conforme os percentuais das respostas no estágio 4 (5\%). Em outros termos, a visão e política da escola se desenvolvem do estágio micro ao estágio intermediário.

Destas análises pode-se inferir que o módulo identidade, pela observação dos seis critérios e dos respectivos estágios, caracteriza a ocorrência da gestão educacional responsável da escola no nível local. Esta inferência é fundamentada pelos valores percentuais das respostas nos estágios 1 e 2, alcançando em alguns dos critérios o estágio 3. Entretanto, deve-se destacar que este estágio fortalece as atividades da escola como sistema. Portanto, ao assumir que os critérios do módulo se constituem em orientações do PRME, pode-se admitir que a gestão responsável pela transformação da gestão educacional é, na percepção dos docentes participantes da pesquisa, apenas parcial. Neste sentido, os conceitos do PRME deixam de se constituírem em referências para a transformação da gestão educacional (GODEMANN et al., 2014).

Para complementar a análise sobre a identidade sustentável da escola, o Gráfico 2 apresenta a visão dos discentes do mesmo curso de administração. São 11 alunos que responderam ao questionário da pesquisa, aplicado conforme descrição apresentada nos procedimentos metodológicos. 
Gráfico 2 - Identidade sustentável da escola PRME-Pública para os discentes

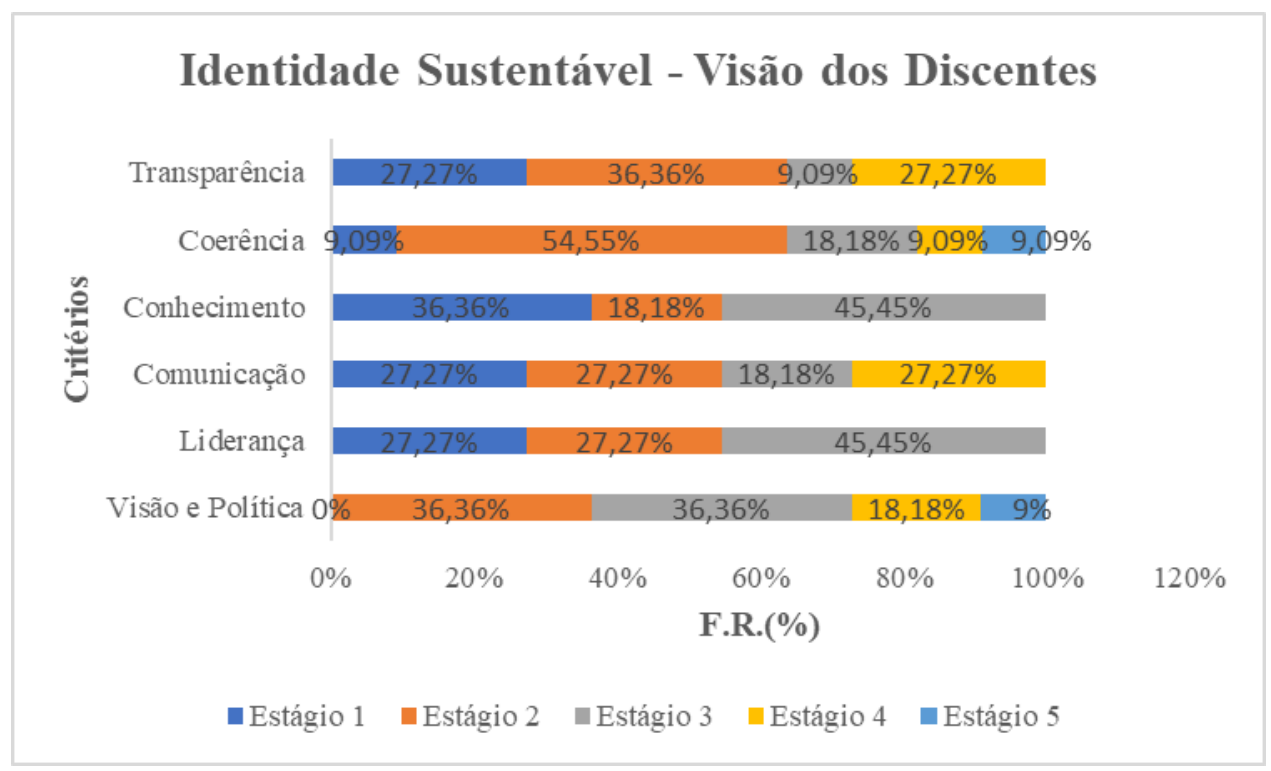

Fonte: Dados da pesquisa

A relevância dos critérios nos diferentes estágios, na visão dos discentes, manifesta-se de forma diferente da dos docentes da mesma instituição, o que pode ser consequência das atividades extracurriculares realizadas pelos discentes, evidenciando que a formação está associada às questões socioambientais demandadas pela sociedade (SÁENZ, 2014). Inicialmente, o critério coerência é identificado em todos os estágios. Ou seja, pelo estágio 5, constata-se que a escola, ao desempenhar os diferentes papeis, este desempenho está, para $9 \%$ dos entrevistados, em sinergia com os atores da sociedade. Além disso, há a coerência no exercício dos papeis, envolvendo a interação com os membros da instituição (estágio 1), a qual implica nas ações de intervenção com ocorrências sistemáticas (estágio 2), as quais envolvem, por sua vez, os departamentos da instituição (estágio 3).

Por outro lado, o critério visão e política não é relevante no estágio 1, mas é desenvolvido nos demais estágios. Em outros termos, a visão dos discentes sobre sustentabilidade da escola contém os valores básicos e éticos da instituição (estágio 2, com $50 \%$ das respostas dos entrevistados), que estão expostos em documentos (estágio 3), os quais foram construídos com a participação dos membros da instituição (estágio 4), e estão integrados ao desenvolvimento da sociedade (estágio 5). Diferentemente da percepção dos docentes, os discentes admitem que a visão e política da instituição sobre sustentabilidade não é verticalmente determinada na instituição. 
Em relação ao critério transparência, o qual envolve a prestação de contas e os resultados relativos a sustentabilidade, a visão dos discentes sobre a escola se distribui pelos quatro estágios, sendo o estágio 2 o mais relevante, com $36 \%$ das respostas. Isto significa que a escola fornece informações aos membros da instituição e aos alunos, mas que essas informações ocorrem, para $27 \%$ dos respondentes no estágio 1, ocasionalmente, limitada a um grupo de funcionários. Não obstante, essas informações se estendem, conforme $27 \%$ das respostas no estágio 4, para as partes interessadas, orientando-se pela cadeia de atores.

Por sua vez, o critério coerência, no Gráfico 2, é relevante, com percentuais diferenciados, nos cinco estágios, demonstrando que a escola é coerente em relação aos papeis que ela desempenha, como educadora, investigadora, e o de introduzir intervenções na sociedade. Entretanto, a relevância desta contribuição está na realização das suas atividades de forma interativa (estágio 2, com $55 \%$ das respostas), e é complementada pela referência à importância do estágio 3, o que significa que as múltiplas atividades ocorrem de forma sistemática, visando estabelecer interações com os institutos de ensino e pesquisa correlatos (estágio 4), fortalecendo a colaboração com a sociedade (estágio 5). É importante destacar que a descrição da coerência pelos estágios torna-se extremamente importante para a compreensão do seu desenvolvimento, colocando este critério de identidade, juntamente com a visão e política, como critérios que fortalecem a apreensão da gestão responsável da escola estendida ao ambiente externo, como admitem os discentes entrevistados.

Diferentemente dos critérios de coerência e visão e política, o conhecimento disponível é orientado para o sistema, estágio 3, com $45 \%$ das respostas dos discentes entrevistados. Para eles, a rede externa é relevante para o desenvolvimento pessoal. Entretanto, a relevância do estágio 1, com $36 \%$ das respostas, expressa que o desenvolvimento pessoal depende de inciativas individuais, para a ampliação do conhecimento, mas que há a constatação, conforme os percentuais de respostas no estágio 2 , da existência de uma equipe responsável para isto. Em outros termos, assume-se que o conhecimento disponível está inserido no ambiente externo, mas depende das iniciativas individuais e da constituição de equipe. Nota-se, pelos estágios 4 e 5 , que não há percentuais sobre o registro de contatos regulares e nem que a sociedade se beneficia das experiências do centro de especialização.

Em relação à comunicação como critério sustentável da escola, ela é relevante, para os entrevistados, nos quatro estágios iniciais. Assim, a escola disponibiliza as informações para 
os membros da equipe, aparecendo regularmente nas reuniões, em publicações e apresentações, ocorrendo de forma estruturada, tanto em revistas científicas quanto em meios públicos de comunicação. Por conseguinte, a comunicação se constitui em meio de disponibilizar informações, mas sem o envolvimento dos diferentes atores na sociedade.

A liderança como critério de identidade, segue a tendência do conhecimento. Ela se desenvolve até o estágio 3. Para 45\% dos entrevistados que destacaram a relevância deste estágio na caracterização da liderança, existe a gestão compartilhada e ela se estende aos membros da equipe, aos funcionários e estudantes. Entretanto, ela não se estende aos stakeholders, aos centros de especialização (estágio 4) e nem integra a instituição como um todo (estágio 5).

Para os discentes entrevistados, a tendência é destacar a relevância dos critérios sob as dimensões internas e externas envolvidas pelas atividades da escola, tendência esta também identificada nos critérios de liderança e visão e política. Em relação à liderança, a relevância está no estágio 3, evidenciando que a escola incentiva e apoia os processos de integração das suas múltiplas atividades, associadas à sustentabilidade, com os membros da equipe de pesquisa e ensino, discentes e funcionários, estágios 1 e 2 .

O critério visão e política, na percepção dos discentes participantes da pesquisa, ocorre nos últimos quatro estágios, sem a sua relevância para o estágio 1, que se refere às atividades da escola para a internalização da gestão educacional responsável. Assim, a relevância dos percentuais nos demais estágios destaca a elaboração de documentos (estágio 2) e a proposição da política de longo prazo (estágio 3). Por essas atividades, os entrevistados admitem que a escola é reconhecida pelos stakeholder, interagindo de forma cooperativa (estágio 4), interação esta que se caracteriza como sendo de longo prazo, com a sociedade (estágio 5).

Na visão dos discentes entrevistados, o que se infere, dos seis critérios que expressam as atividades da escola sobre a sua identidade, é a constatação dos critérios de coerência e visão e política como expressões da identidade da gestão responsável para o ambiente externo. Os demais critérios fortalecem a visão interna da identidade da escola. Deste modo, ratifica-se a importância do desenvolvimento da sustentabilidade nos ambientes interno e externo da escola.

Portanto, pode-se admitir que os discentes do curso de administração, da escola Pública, signatária do PRME, têm a percepção sobre a identidade sustentável da escola mais 
desenvolvida, em comparação com a percepção dos docentes, resultado das possíveis articulações e envolvimentos dos discentes nas práticas escolares. Pode-se, então, admitir que os princípios do PRME são mais perceptíveis aos discentes participantes da pesquisa e que os critérios que representam a identidade sustentável são mais desenvolvidos na visão dos discentes em comparação com a visão dos docentes. Este resultado fortalece a proposta de que a formação dos discentes pela integração dos diversos conteúdos nas disciplinas e nas atividades extracurriculares pode se constituir em uma estratégia para o desenvolvimento da responsabilidade corporativa (HIND; WILSON; LESSEN, 2009).

Para completar a análise da escola pública signatária do PRME, o PPC, como instrumento de gestão da coordenação, é descrito pelo software Iramuteq, Inicialmente, o Quadro 12 apresenta os quatro segmentos constantes do PPC como texto a ser analisado, quais sejam: o perfil do egresso, o objetivo do curso, as metodologias de ensino e aprendizagem adotadas pela escola, e as disciplinas curriculares. Deve-se destacar que esses segmentos foram definidos a partir da própria estrutura do PPC, pois eles devem constar de todos os projetos pedagógicos como orientadores da formação dos alunos, independentemente do tipo da escola, conforme a Lei de Diretrizes e Bases da Educação Nacional reconhecida em 1996. Portanto, o texto reflete a visão do curso, que, pelas definições apresentadas, podem estar ou não associadas à visão de identidade sustentável da escola, conforme o questionário AISHE, ou à visão expressa pelos PRME.

Quadro 12 - PPC da Escola PRME-Pública: Segmentos e descrição

\begin{tabular}{|l|l|}
\hline Perfil do egresso & O egresso do curso de graduação em Administração terá um perfil profissional \\
& caracterizado pelos componentes e competências descritos a seguir. \\
& -Sólida fundamentação técnica e tecnológica; \\
& -Espírito crítico, criativo e competitivo; \\
& -Capacidade de comunicação oral e escrita, e habilidades de relacionamento \\
& Interpessoal; \\
& -Consciência da importância de um aprendizado permanente; \\
& Postura ética como cidadão e profissional, sustentada pela consciência de uma \\
& responsabilidade no contexto social e individual; \\
& -Ter a compreensão da importância da administração como atividade que contribui \\
& para o desenvolvimento econômico e social do país; \\
& -Ter poder de crítica e motivação para atuar como um elemento transformador no seu \\
& campo de atuação e influência; \\
& -Ter competência e efetividade profissional para atuar num ambiente marcado cada \\
& vez mais como globalizado, diversificado, integrado e exigente; \\
& -Ter a convicção de que é necessária uma boa e ampla base cultural aliada aos \\
& conhecimentos específicos, para o efetivo desempenho da administração; \\
& -Ter consciência da importância da cidadania e da ética na vida em sociedade. \\
\hline Objetivos do curso & Contribuir na formação de administradores aptos a atuarem na criação e \\
& administração de organizações e negócios, com efetividade adequada ao novo \\
\hline
\end{tabular}




\begin{tabular}{|c|c|}
\hline & contexto global no qual esta atividade se insere. \\
\hline $\begin{array}{l}\text { Diretrizes/Metodologias } \\
\text { de ensino e } \\
\text { aprendizagem }\end{array}$ & $\begin{array}{l}\text { Construir o processo de aprendizagem dentro do contexto realístico social, político- } \\
\text { econômico e profissional; } \\
\text { Buscar o equilíbrio do desenvolvimento cognitivo, pessoal (afetivo e social), e } \\
\text { interpessoal; } \\
\text { Prover uma aprendizagem não mecanizada, envolvendo conhecimentos, experiências } \\
\text { e vivências, de forma que o graduando seja capaz de formular e resolver problemas, } \\
\text { bem como transferir o que aprendeu para outras situações da vida; } \\
\text { Acompanhar o processo de aprendizagem do aluno; } \\
\text { Melhorar o contato entre o aluno e o professor dentro e fora da sala de aula por meio } \\
\text { de uma postura ativa do mesmo, de incentivo aos alunos em seu processo de } \\
\text { aprendizagem; } \\
\text { Fomentar a cooperação entre os alunos através de trabalhos em equipe, a fim de que } \\
\text { o raciocínio seja estimulado e o entendimento aprofundado; } \\
\text { Alocar eficientemente o tempo em sala de aula, distribuindo de forma adequada as } \\
\text { atividades. }\end{array}$ \\
\hline Disciplinas curriculares & $\begin{array}{l}\text { Introdução à Psicologia, Instituições de Direito, Gestão Empresarial Estudo de } \\
\text { Modelos Aplicados à Economia e Administração, Comunicação e Trabalho Grupo, } \\
\text { Matemática Aplicada à Administração, Filosofia, Contabilidade Empresarial, } \\
\text { Introdução à Sociologia, Direito do Trabalho, Teoria das Organizações, Introdução à } \\
\text { Estatística, Ética e Política, Técnicas de Pesquisa, Meio Ambiente e } \\
\text { Sustentabilidade, Contabilidade e Custos, Comportamento Organizacional, } \\
\text { Matemática Financeira, Estatística Aplicada, Desenvolvimento de Sistemas de } \\
\text { Informação, Direito Tributário, Teoria Econômica, Macroeconomia, Planejamento, } \\
\text { Competitividade e Controle, Análise Financeira, Marketing, Administração de } \\
\text { Operações, Estatística Aplicada à Administração, Direito Comercial, Introdução à } \\
\text { Microeconomia, Estágio Supervisionado, Estrutura Organizacional, Sociologia } \\
\text { Aplicada à Administração, Administração Financeira, Marketing II, Administração } \\
\text { de Operações II, Pesquisa Operacional I, Administração de Recursos Humanos I, } \\
\text { Administração Financeira II, Comportamento do Consumidor, Pesquisa Operacional } \\
\text { II, Estatística Aplicada à Administração III, Sistemas Integrados de Informação, } \\
\text { Orçamento Empresarial, Gestão da Inovação, Administração de Recursos Humanos } \\
\text { II, Finanças Internacionais, Sistemas de Informação de Pesquisa de Marketing, } \\
\text { Administração Logística e da Cadeia de Suprimentos, Economia de Empresas, } \\
\text { Elaboração de Projetos, Política de Negócios, Mercado de Capitais I, Gestão da } \\
\text { Qualidade I, Sistemas de Tomada de Decisão, Administração Pública, Economia } \\
\text { Brasileira, Política de Negócios II, Modelos de Negociação, Planejamento e Gestão } \\
\text { Estratégica de Marketing, Social nas Organizaçôes, Trabalho de Conclusão de Curso } \\
\text { I, Trabalho de Conclusão de Curso II, Estágio III, Estágio IV. }\end{array}$ \\
\hline
\end{tabular}

Fonte: Elaborado pela autora

O Quadro 12 é analisado, conforme apresentado na revisão de literatura, pelos Princípios para Educação Executiva Responsável (PRME), visando o alinhamento das propostas das escolas na formação dos discentes e na incorporação de valores universais nas diretrizes de ensino e nas disciplinas, orientados para a construção da sociedade global e inclusiva. Sob esta perspectiva, o perfil do egresso é definido pelas competências profissionais associadas às funções do administrador, com o objetivo de administrar organizações e os negócios. Para tanto, as diretrizes estão delimitadas pelos contextos político e econômico, no âmbito da profissão. Como consequência, o enfoque da aprendizagem se 
restringe à sala de aula, às relações professor/aluno e ao trabalho em equipe, envolvendo o conjunto de disciplinas que visam à profissionalização do aluno, como administrador da organização e dos negócios.

Em função destas características, o PPC se constitui em uma referência extremamente rígida para a formação em sustentabilidade, dificultando mudanças das temáticas que são demandadas pela sociedade. A tendência para essas mudanças, a despeito da ocorrência contínua da degradação dos recursos naturais, ainda é lenta, pois a introdução da sustentabilidade nos currículos de Administração é uma das dificuldades na formação de futuros administradores (GONÇALVES-DIAS; HERRERA; CRUZ, 2013).

O que se infere é que esta dificuldade está atrelada a dois fatores, quais sejam, à concepção do PPC e à identificação, pelos dados apresentados, da tendência da identidade das escolas se concentrarem no ambiente interno. Especialmente em relação ao PPC da escola pública signatária do PRME, o texto apresentou 665 ocorrências de 366 palavras. Do total de palavras, $75,96 \%$ são hapax, ou seja, palavras que aparecem apenas uma vez no texto. $\mathrm{O}$ Gráfico 3, representado pelo diagrama de Zipf, mostra o comportamento da ocorrência das palavras no texto, considerando a ocorrência do número de palavras, na horizontal, e as frequências de ocorrência na vertical.

Gráfico 3 - Comportamento da ocorrência das palavras - Escola PRME - Pública

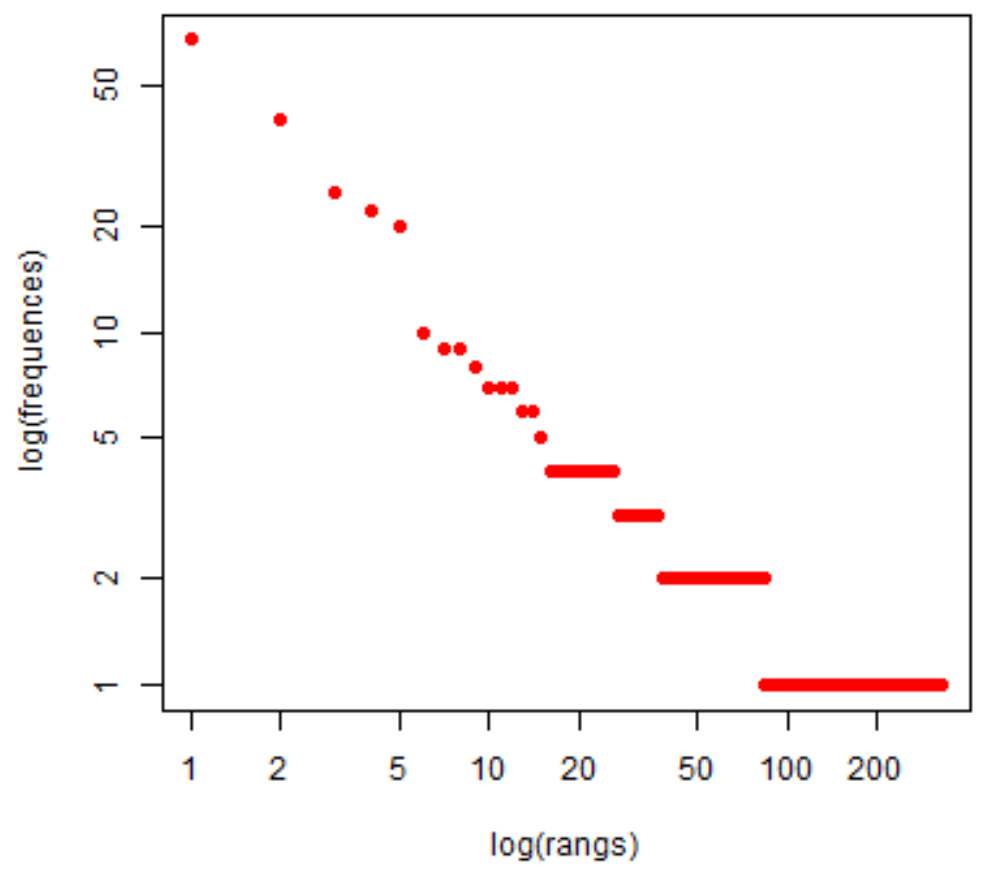

Fonte: Dados da pesquisa 
De acordo com o Gráfico 3, a concentração de palavras está entre aquelas que ocorrem até quatro vezes, sendo que o maior número de palavras ocorre apenas uma vez. Pode-se identificar que existem mais de 80 palavras que ocorrem apenas uma vez, ou seja, possuem uma frequência baixa. Por outro lado, há um número pequenos de palavras que ocorrem mais de 20 vezes, possuindo uma frequência alta de ocorrência.

Enquanto o objetivo do diagrama de Zipf é demonstrar a distribuição de frequência das palavras, não apresentando quais são as palavras que ocorrem, a Figura 3 complementa a compreensão da distribuição das palavras no PPC desta escola pública signatária, pois ela apresenta a nuvem de palavras de acordo com a frequência com que elas aparecem no plano pedagógico.

Figura 3 - Nuvem de palavras - Escola PRME - Pública

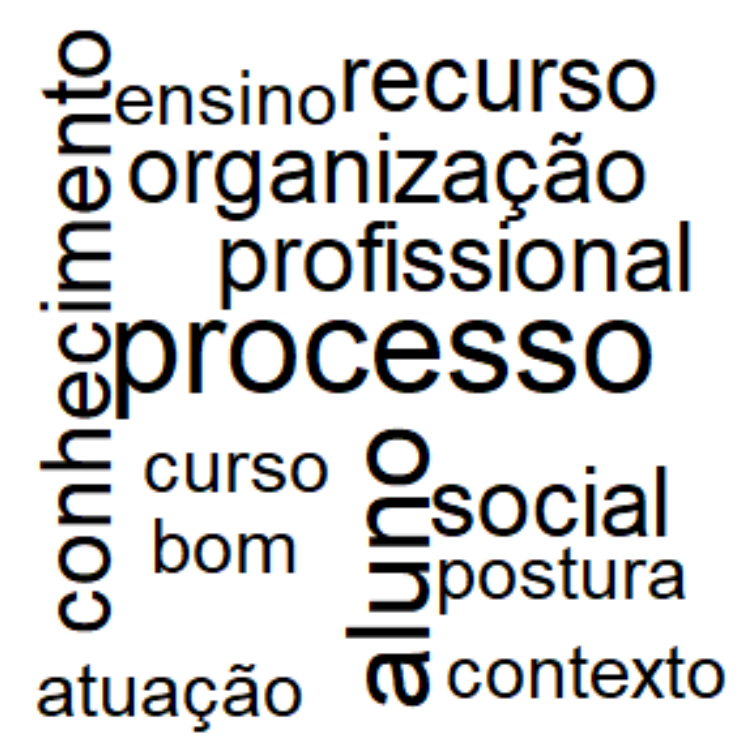

Fonte: Dados da pesquisa

Pode-se observar que as palavras que aparecem com maior frequência são: "administração", com frequência 7; "aprendizagem" e "processo", com frequência 6; "aluno", frequência 5; e "conhecimento", com frequência 4. As demais aparecem com uma frequência inferior a 3. Identifica-se que são palavras usualmente empregadas para estruturar os projetos pedagógicos, visando a definição de diretrizes para a formação dos alunos. Pode-se destacar que, apesar de a palavra "conhecimento" não ter uma frequência significativa no PPC, ela é um dos critérios do módulo identidade do AISHE na promoção da identidade sustentável da escola. Portanto, pode-se inferir que a escola em questão apresenta evidências de que o PPC 
orienta a formação dos alunos sob um dos critérios do AISHE, ou seja, há uma orientação no desenvolvimento de uma gestão responsável pela escola. Entretanto, em conformidade com as respostas dos docentes e discentes desta escola, o conhecimento depende das iniciativas individuais, que se estruturam por um plano elaborado pela equipe, estando disponibilizado às partes interessadas. Assim, há a adequação dos interesses dos stakeholders à elaboração do plano de desenvolvimento pessoal.

Não obstante, a estratégia de redirecionamento pode estar na identificação de disciplinas que possam abordar aqueles conteúdos. Neste sentido, na análise das disciplinas que constam na matriz curricular dessa escola, ao longo dos 10 períodos do curso, apenas 2 disciplinas são ofertadas com os conteúdos voltados para a sustentabilidade, uma das quais é Meio Ambiente e Sustentabilidade, ofertada no $2^{\circ}$ período do curso, e a outra, Responsabilidade Social nas Organizações, oferecida no $5^{\circ}$ período do curso. Se, a princípio, esta inserção representa a introdução das demandas das sociedades, ela, ao mesmo tempo, expressa a natureza lenta da mudança que ocorre em relação à elaboração do PPC do curso.

Não obstante, esta mudança poderá ser intensificada quando ocorrer o maior comprometimento da escola com o modelo PRME de gestão educacional, uma vez que o PPC desta escola foi elaborado antes de obter o status de signatário. Como consequência, se houver a réplica da investigação sobre a identidade sustentável da escola, os estágios de desenvolvimento dos critérios associados a ela, serão diferentes. Portanto, é relevante a proposição de reaplicação da investigação, diferenciando as escolas pelo período, antes e depois, do status de signatária do PRME. Se, por um lado, esta constatação revela a existência de desafios que a escola possui para a introdução da sustentabilidade nos cursos de Administração (GONÇALVEZ-DIAS; HERRERA; CRUZ, 2013), por outro, torna-se difícil empregar a sustentabilidade como referência para a transformação das ações nas empresas (SCHRETTLE et al.,2014).

\subsubsection{Escola PRME - Privada}

A identidade sustentável da escola privada signatária do PRME é, pelas respostas dos 12 docentes, apresentada no Gráfico 4. Conforme os estágios em que os critérios são avaliados, pode-se admitir que a escola não atinge plenamente a gestão educacional responsável, mais em função da não apreensão dos conteúdos do que decorrente da reflexão crítica exercida pelos docentes sobre suas práticas no contexto da instituição (TARDIFF, 
2002). Dos cinco estágios, quatro deles são mais relevantes, para os respondentes, no estágio 1. Apenas o critério de liderança se destaca no estágio 2. Com isso, os resultados revelam a tendência de a identidade sustentável da escola estar concentrada nas atividades dos membros da equipe. Por exemplo, a transparência se dá quando os membros requerem as informações; a coerência na execução dos papéis da escola é devida à interação entre eles; o conhecimento depende das iniciativas individuais; a comunicação é entre os membros; a liderança é sobre os membros da equipe (estágio 1), mas se estende aos estudantes e funcionários (estágio 2), e a visão e política estão implícitas nos documentos, sendo elaboradas de cima para baixo.

A despeito desta tendência, identifica-se, também, que os critérios de coerência, conhecimento, comunicação e visão e política se estendem aos estágios 4 e 5 . Isto revela que a escola, pelos percentuais das respostas dos docentes, possui alguma sinergia com os atores do ambiente externo, destacando os stakeholders, com os centros de especialização e que os resultados de pesquisas estão sendo disponibilizados aos stakeholders.

Gráfico 4 - Identidade sustentável da escola PRME-Privada para os docentes

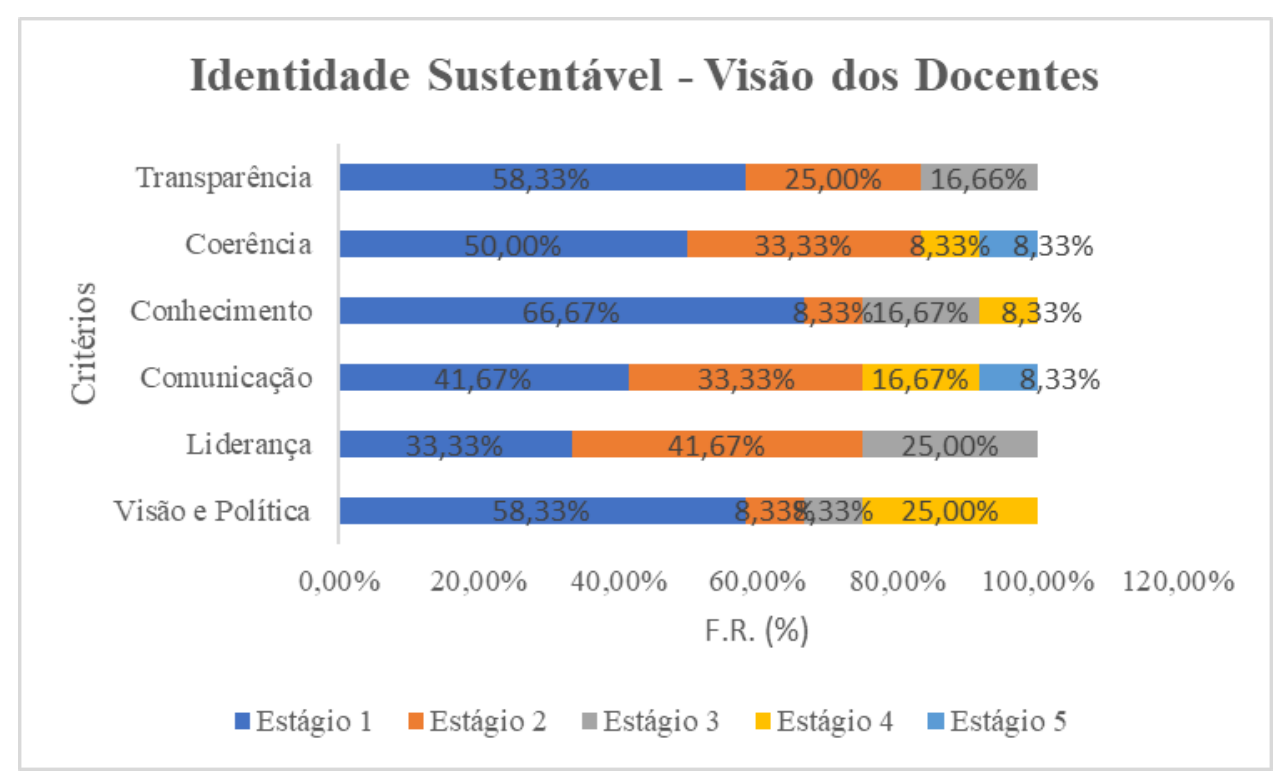

Fonte: Dados da pesquisa

O dado interessante do Gráfico 4 é que as respostas dos docentes sobre a identidade sustentável da escola pelos critérios de conhecimento, comunicação e visão e política reforçam a tendência de a identidade sustentável se concentrar nos estágios internos à escola. Por exemplo, dos três critérios, apenas o critério de visão e política se destaca com o 
percentual de $25 \%$ no estágio 4 . Os dois outros critérios possuem o percentual de $8 \%$, respectivamente, conhecimento no estágio 4, e comunicação no estágio 5. Em síntese, quando os critérios atingem os estágios que envolvem os atores da sociedade, os percentuais das respostas são relativamente menores do que os que reforçam a identidade da escola no ambiente interno.

Para complementar a análise sobre a identidade sustentável desta escola, o Gráfico 5 apresenta a visão dos discentes sobre os seis critérios de identidade para o mesmo curso de administração. São 27 alunos que responderam ao questionário da pesquisa, com os percentuais distribuídos entre os cinco estágios, especialmente os critérios de transparência, coerência, conhecimento e comunicação. Apesar desta distribuição percentual, os valores se concentram do primeiro ao terceiro estágio, evidenciando a tendência de a identidade sustentável estar implícita às atividades internas da escola.

Gráfico 5 - Identidade sustentável da escola PRME-Privada para os discentes

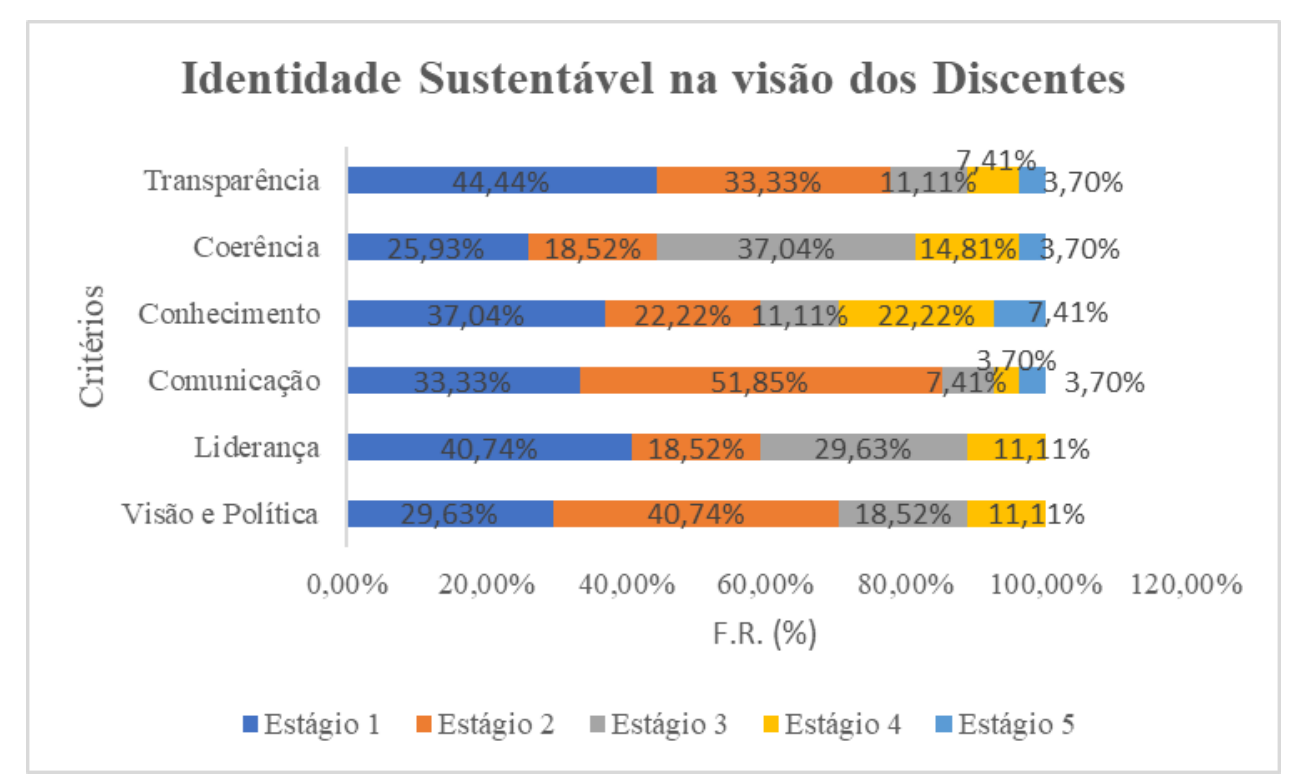

Fonte: Dados da pesquisa

Os critérios de liderança e de visão e política se estendem até o estágio 4, mas o percentual de respostas dos discentes, nos três primeiros estágios, atingem $90 \%$ em ambos os critérios, conforme se identifica no Gráfico 5. É a tendência de a identidade sustentável da escola concentrar-se mais entre os membros da equipe, onde as informações são disponibilizadas quando requeridas e quando há a necessidade de apresentá-las em reuniões. 
Os valores percentuais dos critérios de comunicação - no segundo estágio 52\%, e de visão e política $41 \%$ - reforçam o argumento de que, se as informações são apresentadas em documentos, nas reuniões, e os valores básicos e éticos da escola apresentam-se, igualmente, em documentos, a gestão concentra-se na realização de curto prazo.

Comparando-se as respostas dos docentes com as dos discentes sobre a identidade sustentável da escola, pode-se inferir que os discentes possuem a percepção mais abrangente do que os docentes. Este dado constata a relevância das atividades extracurriculares na formação discente e /ou a transversalidade para a integração da sustentabilidade nas diferentes disciplinas (HIND; WILSON; LENSSEN, 2009). Esta abrangência se justifica pelos percentuais das respostas, ainda que em valores menores, nos estágios 4 e 5 . Enquanto o estágio 4 estende as atividades aos stakeholders, orientando-se pelas cadeias de atores, com ações de longo prazo, o estágio 5 destaca a importância do feedback da sociedade para a escola, possui sinergia com os atores, há um centro de excelência que contribui para a sociedade, via um processo de comunicação ativo. A ressalva é que as respostas dos discentes ao item da integração da escola no ambiente externo - e que resultam percentuais obtidos podem ter sido dadas mais para se identificar que a escola não é uma instituição isolada, à parte do seu contexto.

Para completar a análise da escola pública signatária do PRME, o PPC, como instrumento de gestão da coordenação, é descrito pelo software Iramuteq. Esta análise deve ser iniciada com as informações constantes do Quadro 13. Este quadro apresenta os quatro segmentos constantes do PPC como texto a ser analisado, quais sejam: o perfil do egresso, o objetivo do curso, as metodologias de ensino e aprendizagem adotadas pela escola e as disciplinas curriculares. Deve-se destacar que esses segmentos foram definidos a partir da própria estrutura do PPC, pois eles devem constar de todos os projetos pedagógicos como orientadores da formação dos alunos, independentemente do tipo da escola. Portanto, o texto reflete a visão do curso, que, pelas definições apresentadas, podem estar ou não associadas à visão de identidade sustentável da escola, conforme o questionário AISHE ou ao modelo PRME.

Quadro 13 - PPC da Escola PRME-Privada: Segmentos e descrição

\begin{tabular}{|l|l|}
\hline Perfil do egresso & $\begin{array}{l}\text { Busca-se a formação de um profissional generalista que domine os fundamentos da } \\
\text { administração geral e das suas diversas áreas epistemológicas para garantir a sua rápida } \\
\text { adaptação à dinâmica do mercado, capaz de compreender as questões científicas, } \\
\text { técnicas, organizacionais, sociais e econômicas. Deseja-se ainda formar um }\end{array}$ \\
\hline
\end{tabular}




\begin{tabular}{|c|c|}
\hline & $\begin{array}{l}\text { profissional que seja capaz de realizar inovações, pesquisa, projetos e resolver } \\
\text { problemas nas organizações e também na comunidade social; que tenha espírito } \\
\text { empreendedor, capaz de vislumbrar novas oportunidades ou negócios ainda não } \\
\text { explorados, podendo, inclusive, direcionar essa qualidade para a criação de } \\
\text { empreendimentos próprios; que esteja adaptado às diversas estruturas e culturas } \\
\text { organizacionais, capaz de desenvolver-se no espaço ocupacional de todas as } \\
\text { modalidades organizacionais, desde o nível operacional até o estratégico; que seja, } \\
\text { fundamentalmente orientado para a vocação ética e humanística de respeito à } \\
\text { sociedade e à comunidade, tendo consciência da complexidade e amplitude global da } \\
\text { sociedade, para avaliar os impactos de suas ações ao longo do tempo e nas dimensões } \\
\text { sociais, ambientais e econômicas. } \\
\text { As competências a serem desenvolvidas para a formação do administrador são as } \\
\text { seguintes: } \\
\text { Técnica e profissional } \\
\text {-Ter o domínio dos conceitos e práticas atuais ligados à administração financeira, } \\
\text { marketing, pessoas, serviços e operações, estratégia e tecnologia da informação, em } \\
\text { distintos modelos organizacionais. } \\
\text { Decisão e inovação } \\
\text { - Exercer, em sua plenitude e em seus diversos graus, o processo de tomada de decisão, } \\
\text { na gestão de recursos e prazos e no processo de planejamento organizacional; } \\
\text {-Ter capacidade inovadora com absorção e transferência de conhecimentos; } \\
\text { - Ser capaz de analisar e utilizar dados e informações técnicas, aperfeiçoamento de } \\
\text { processos, produtos e serviços. } \\
\text { Relacional } \\
\text { - Desenvolver a liderança e o trabalho em equipe; } \\
\text { - Ser capaz de se comunicar eficazmente, com articulações internas e externas à } \\
\text { organização, com constante aprimoramento do relacionamento interpessoal; } \\
\text { - Ser negociador. } \\
\text { Humanística } \\
\text {-Ter postura ética, capaz de compreender a responsabilidade social e agir em prol da } \\
\text { sustentabilidade, em suas dimensões econômicas, sociais e ambientais; } \\
\text { - Dominar os princípios e fundamentos da justiça, equidade e liberdade. }\end{array}$ \\
\hline Objetivos do curso & $\begin{array}{l}\text { O Curso de Administração visa formar o "Bacharel em Administração", segundo o que } \\
\text { preconiza a legislação vigente e as diretrizes nacionais do curso. Os seus objetivos } \\
\text { visam desenvolver competências sociais, organizacionais e técnicas para capacitar o } \\
\text { aluno a participar e modificar a realidade social e organizacional em busca de maior } \\
\text { desenvolvimento e bem estar social; fundamentar este processo com as bases teóricas e } \\
\text { conceituais adequadas, amparadas por ações didáticas e pedagógicas de vanguarda, } \\
\text { essenciais ao ensino, a pesquisa e a formação profissional e sensibilizar para as práticas } \\
\text { adequadas à realidade organizacional brasileira e internacional sem perder o espírito } \\
\text { crítico e humanista que deve nortear as intervenções profissionais. }\end{array}$ \\
\hline $\begin{array}{l}\text { Diretrizes de ensino e } \\
\text { aprendizagem }\end{array}$ & $\begin{array}{l}\text { O conceito de competências utilizado para a formação do perfil do egresso incorporou } \\
\text { novas abordagens voltadas à aprendizagem baseada na mobilização de recursos e } \\
\text { saberes para produzir resultados práticos e de qualidade. Considerando os eventos } \\
\text { organizacionais como mutáveis o aluno será preparado para produzir serviços de } \\
\text { qualidade e comunicar-se com efetividade. Em complemento será adotada a } \\
\text { abordagem das competências mais atual que significa agregar mais valor individual } \\
\text { com a ampliação da aprendizagem, e estar preparado para agregar mais valor } \\
\text { organizacional e social. Para estimular estas competências, é criado no curso de } \\
\text { administração um espaço que contempla uma sequência de disciplinas articuladas que } \\
\text { abre para uma perspectiva transversal e interdisciplinar com as áreas epistemológicas e } \\
\text { também de outros campos do saber. Estas disciplinas vão desenvolver pesquisas, } \\
\text { projetos e práticas nas organizações, novos conhecimentos com optativas livres, } \\
\text { organização de eventos tais como semanas acadêmicas, atividades complementares, } \\
\text { estágios, vivências em empresas e trabalhos de conclusão de curso. }\end{array}$ \\
\hline Disciplinas curriculares & $\begin{array}{l}\text { Ciências Sociais Aplicadas à Administração I, Contabilidade Geral, Estatística I, } \\
\text { Marketing, Introdução Direito ao Direito Comercial, Matemática Aplicada à }\end{array}$ \\
\hline
\end{tabular}




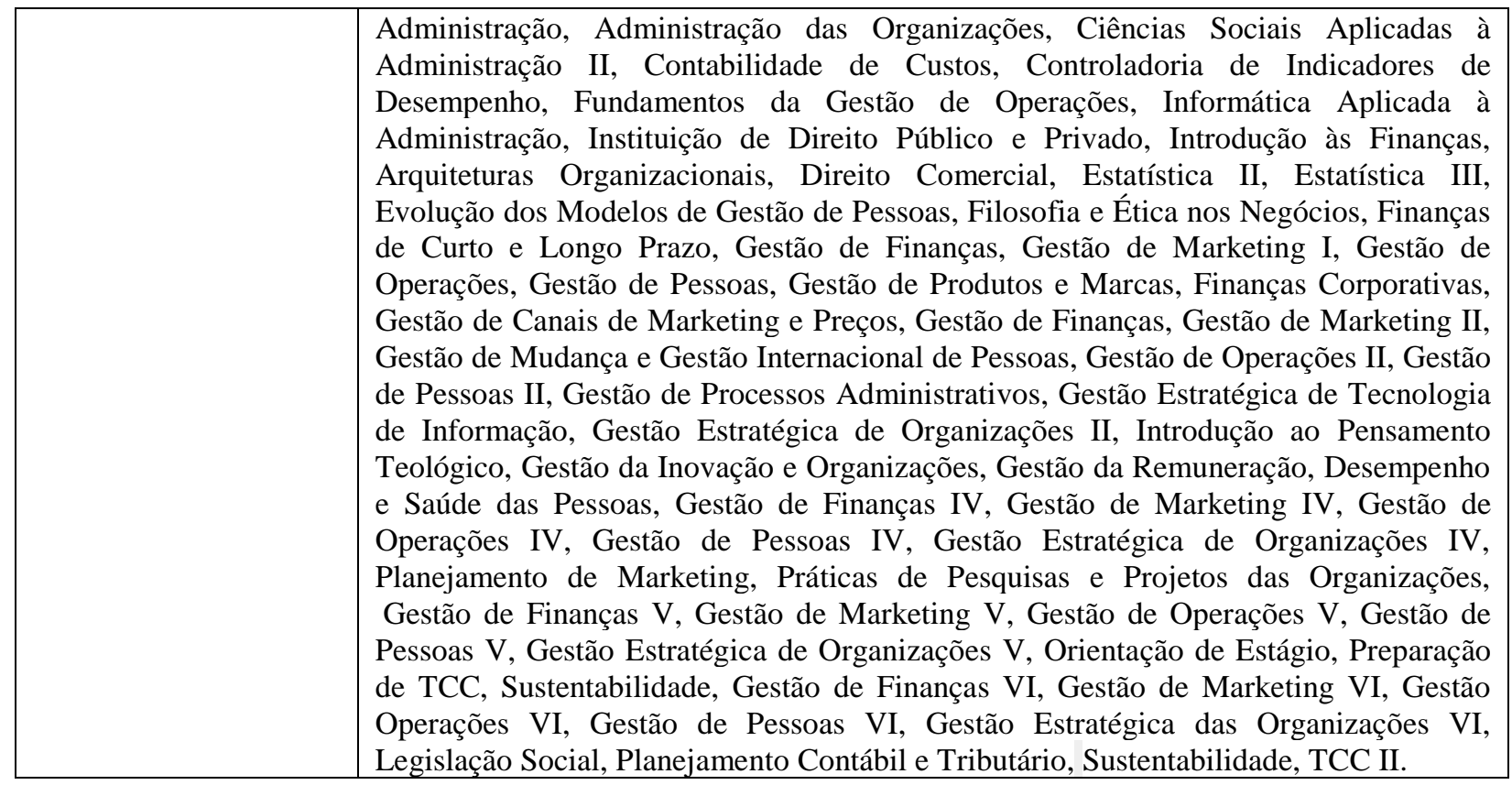

Fonte: Elaborado pela autora

O Quadro 12 é analisado, conforme apresentado na revisão de literatura, pelos Princípios para Educação Executiva Responsável (PRME), visando ao alinhamento das propostas das escolas na formação dos discentes e na incorporação de valores universais nas diretrizes de ensino e nas disciplinas, orientados para a construção da sociedade global e inclusiva. Sob esta perspectiva, esta escola enfatiza o perfil do egresso pelas competências técnica, profissional, habilidades em decidir e inovar, habilidades em se relacionar com as pessoas e pela formação humanística.

O que se destaca no perfil do egresso é a formação pelas habilidades em relações às pessoas e à formação humanística, as quais envolvem a formação de lideranças e de negociadores, além da formação ética, onde a responsabilidade social é definida como sendo a responsabilidade voltada às dimensões econômicas, socias e ambientais. Constata-se que, pelos termos empregados, o perfil do egresso é expresso por vocábulos que constam do modelo PRME e dos critérios de identidade da escola.

Com esta característica na formação do egresso, o objetivo do curso enfatiza o desenvolvimento de competências sociais, organizacionais e técnica, focalizando a participação do profissional em intervenções que alterem a realidade, visando à melhoria do bem-estar social. Para tanto, as diretrizes de ensino e aprendizagem são definidas e empregadas para estimular as competências econômicas, sociais e ambientais. Assim, o curso de administração contempla disciplinas articuladas, abordando temas transversais e 
interdisciplinares, com o estimulo para a pesquisa, a organização e a participação em eventos e estágios vivenciais em empresas. Conceitualmente, são proposições implícitas tanto no modelo PRME quanto nos critérios de sustentabilidade da escola, evidenciando a grande semelhança de termos empregados pelo PPC, pelo modelo PRME e pelos critérios de identidade sustentável da escola.

Se em termos conceituais o PCC desta escola apresenta abrangência e alternativas diversas à formação do egresso, podendo-se assumir que ela estaria redefinindo a educação para a gestão do futuro pelo PRME (ALCARAZ; THIRUVATTAL, 2010), em termos de disciplinas isto não ocorre. Ou seja, as disciplinas são apresentadas de forma a desenvolverem a capacidade técnica, com apenas uma disciplina sobre sustentabilidade, mas sem a inclusão de complementos que poderiam delimitar o seu propósito no curso. Portanto, o que infere deste PPC é que a formação dos egressos se enquadra na abordagem técnica, e que os complementos desta formação, como liderança, ambiente e bem-estar social, dependem de disciplinas, das práticas e de atividades não regularmente requeridas. Em outros termos, a abordagem conceitual do PPC desta escola é uma, e a sua prática na formação dos discentes é outra.

Em certo sentido, esta conclusão é fortemente corroborada pelas respostas dos docentes aos critérios de identidade sustentável da escola e constatada pelas repostas dos discentes aos mesmos critérios. A diferença entre ambos é que algumas atividades, talvez as que permitem iniciativas dos estudantes, estejam alcançando o ambiente externo da instituição e a formação parcial, em relação às proposições do modelo PRME e aos critérios de sustentabilidade da escola.

Este argumento pode ser mais bem compreendido pela análise dos conteúdos do PPC da escola. Inicialmente, esses conteúdos são expressos pelo número de vocábulos empregados. Constatou-se 650 ocorrências de 355 palavras. Do total de palavras, 74,93\% são hapax, ou seja, palavras que aparecem apenas uma vez no texto. O Gráfico 6, representado pelo diagrama de Zipf, mostra o comportamento da ocorrência das palavras no texto, considerando a ocorrência do número de palavras, na horizontal, e as frequências de ocorrência na vertical. 
Gráfico 6 - Comportamento da ocorrência das palavras - Escola PRME-Privada

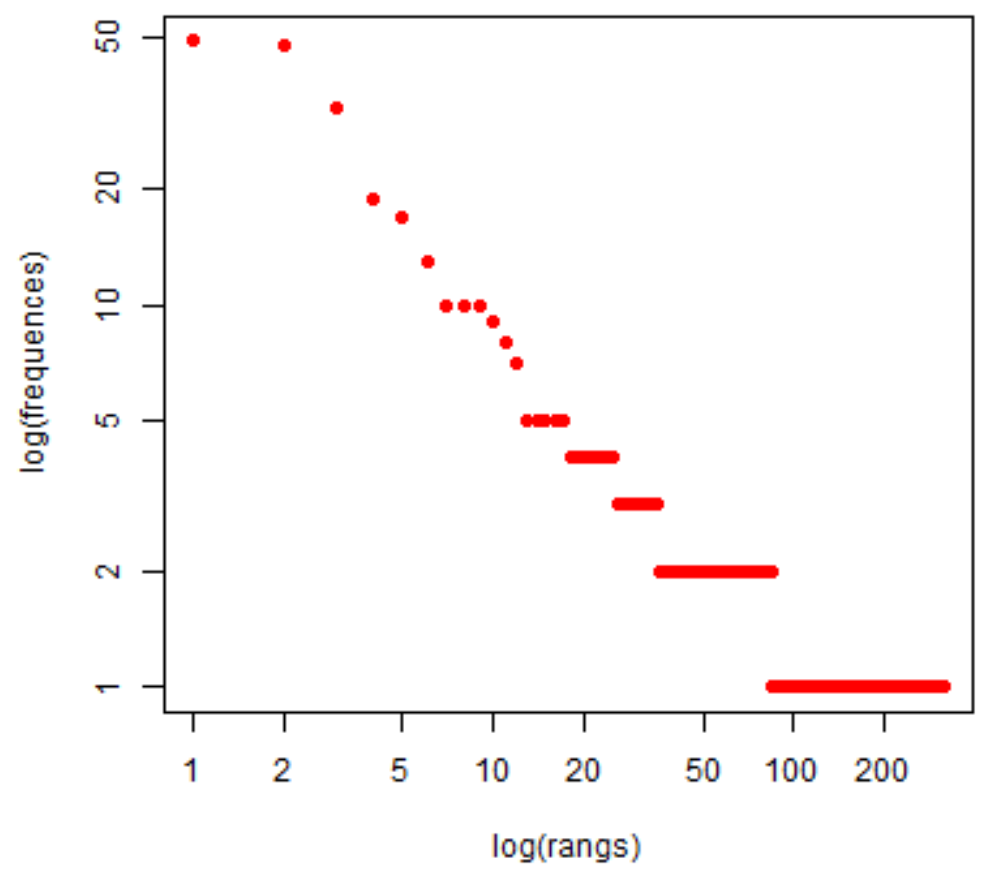

Fonte: Dados da pesquisa

De acordo com o Gráfico 6, a concentração de palavras está entre aquelas que ocorrem até quatro vezes, sendo que o maior número de palavras ocorre apenas uma vez. Pode-se identificar que existem mais de 90 palavras que ocorrem apenas uma vez, ou seja, possuem uma frequência baixa. Por outro lado, há um número pequeno de palavras que ocorrem mais de 15 vezes, possuindo uma frequência alta de ocorrência.

Enquanto o objetivo do diagrama de Zipf é demonstrar a distribuição de frequência das palavras, não apresentando quais as palavras que ocorrem, a Figura 4 complementa a compreensão da distribuição das palavras no PPC desta escola privada, signatária, pois ela apresenta a nuvem de palavras de acordo com a frequência com que elas aparecem no plano pedagógico. 
Figura 4 - Nuvem de palavras - Escola PRME - Privada

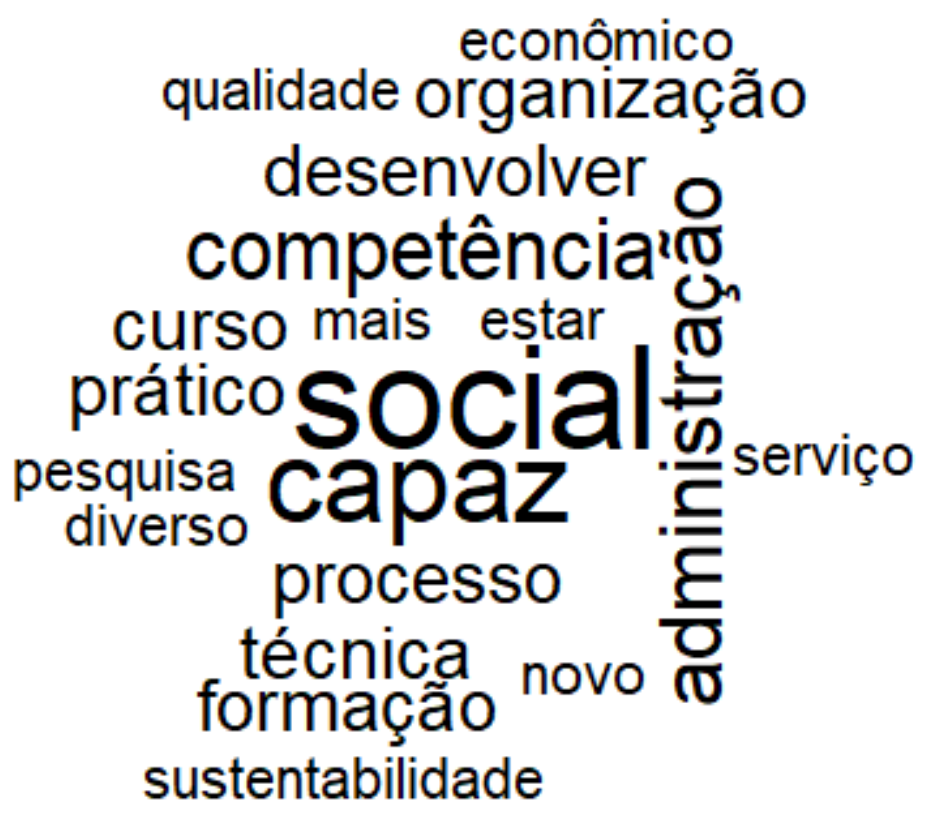

Fonte: Dados da pesquisa

A palavra que aparece com maior frequência é "social", com frequência 9; "capaz", com frequência 7; seguidas pelas palavras "competência" e "administração", com frequência 5. Vale observar o destaque para as palavras "formação", com frequência 4, e "sustentabilidade" e "pesquisa", com frequência 3, pois são palavras que representam alguns princípios do PRME e critérios de identidade, segundo o AISHE, na promoção da identidade sustentável da escola.

Portanto, ao considerar a presença destes vocábulos no PPC, pode-se inferir que a escola em questão apresenta evidências de que o PPC emprega termos comuns aos que são empregados no instrumento AISHE, sobre a orientação para a formação de uma gestão responsável, pela escola. Não obstante, ao identificar que a oferta das disciplinas não direciona a este desenvolvimento, constata-se a tendência da instituição em apresentar as diretrizes gerais, apenas, deixando opções para a complementação da formação dos discentes. Assim, a formação dos discentes ocorre por meio do ensino, pesquisa e extensão universitária (FARIAS, 2014).

Este argumento é corroborado tanto pelas respostas dos docentes, quanto pelas dos discentes, sobre os critérios de identidade da escola. Como constatado, ambos expressam a valorização dos estágios 1 e 2, sobretudo na avaliação dos critérios de identidade. Com isto, as atividades da escola se concentram no ambiente interno, envolvendo especialmente os 
membros da equipe e estudantes, sendo disponibilizadas informações, quando requeridas, e apresentadas em documentos nas reuniões.

\subsubsection{Escola Não PRME - Pública}

A discriminação da identidade sustentável da Escola Não PRME - Pública é apresentada no Gráfico 7. Esta discriminação é de 8 docentes do curso de administração que responderam ao questionário encaminhado.

Gráfico 7 - Identidade sustentável da escola Não PRME-Pública para os docentes

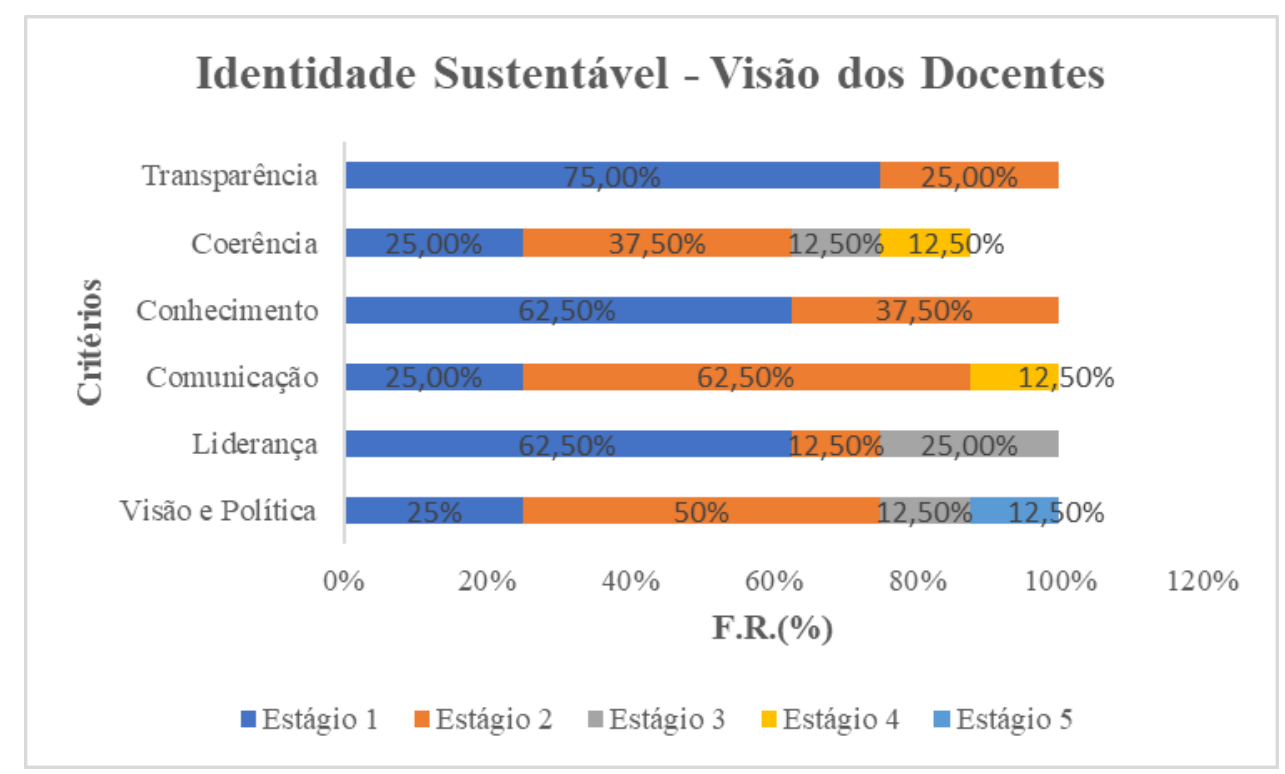

Fonte: Dados da pesquisa

Diferentemente das análises dos gráficos das escolas signatárias, o módulo identidade na escola Não PRME-Pública é caracterizado de forma diferente. Isto é, os módulos referentes à coerência, e à visão e política, desenvolvem-se por quatro estágios, sendo que o último, entre eles, é diferente. Mais especificamente, o critério coerência é relevante pelos exemplos que a escola possui (estágio 2), o que envolve os departamentos que interagem continuamente (estágio 4). Entretanto, visão e política também é relevante pelo estágio 2, pois os seus valores básicos e éticos estão em documentos e apresentam a visão integrada de desenvolvimento da sociedade (estágio 5).

Por sua vez, os critérios de comunicação e de liderança se desenvolvem em três estágios, sendo que os estágios relevantes são diferentes para ambos, além da diferença em 
relação ao alcance do último estágio. No critério comunicação, o estágio 2 revela que as comunicações são estruturadas (estágio 2), que são apresentadas aos membros da equipe (estágio 1), e também que estão disponíveis em revistas científicas e outras publicações (estágio 4). No que diz respeito à liderança, ela se estende aos membros da pesquisa (estágio 1) e é apoiada pela escola de forma participativa (estágio 3), envolvendo também estudantes e funcionários (estágio 2).

De forma mais restrita, os critérios de transparência e de conhecimento atingem o desenvolvimento até o segundo estágio, sendo o estágio 1 o mais relevante para ambos. Assim, no que se refere à transparência, para $75 \%$ dos docentes participantes da pesquisa a escola fornece, quando requerida, informações sobre metas individuais, processos, etc., enquanto o conhecimento depende, fundamentalmente, das iniciativas individuais, como destacam $62 \%$ dos respondentes no estágio 1 , a despeito da existência das condições de infraestrutura, conforme identificado pelo estágio 2 .

Seguindo a sequência dos critérios no Gráfico 7, a transparência das informações e dados está restrita ao grupo de pessoas da escola, estágio 1, e periodicamente os resultados sobre as suas atividades são apresentados aos membros da instituição e alunos (estágio 2). Portanto, este critério é pouco desenvolvido, centralizando nos membros internos as atividades do curso de administração.

Para os docentes participantes desta escola, os seis critérios do módulo identidade expressam a visão de gestão responsável local, essencialmente determinada pelos desenvolvimentos nos estágios 1 e 2 . Entretanto, sobressaem-se a transparência e a visão política como critérios que alcançam o ambiente externo da instituição. Por outro lado, a comunicação e a liderança, aspectos essenciais na constituição da gestão responsável, são poucos desenvolvidos nos diferentes estágios. Neste sentido, destaca-se a proposição sobre a adequação da escola e dos professores para a mudança educacional e a formação de líderes (HARGREAVES, 2007).

Outro componente da análise sobre a identidade sustentável desta escola é o conjunto de alunos que estão se formando no curso de administração. São 12 alunos que responderam ao questionário da pesquisa, e os dados evidenciando o módulo identidade da escola são apresentados no Gráfico 8. 
Gráfico 8 - Identidade sustentável da escola Não PRME-Pública para os discentes

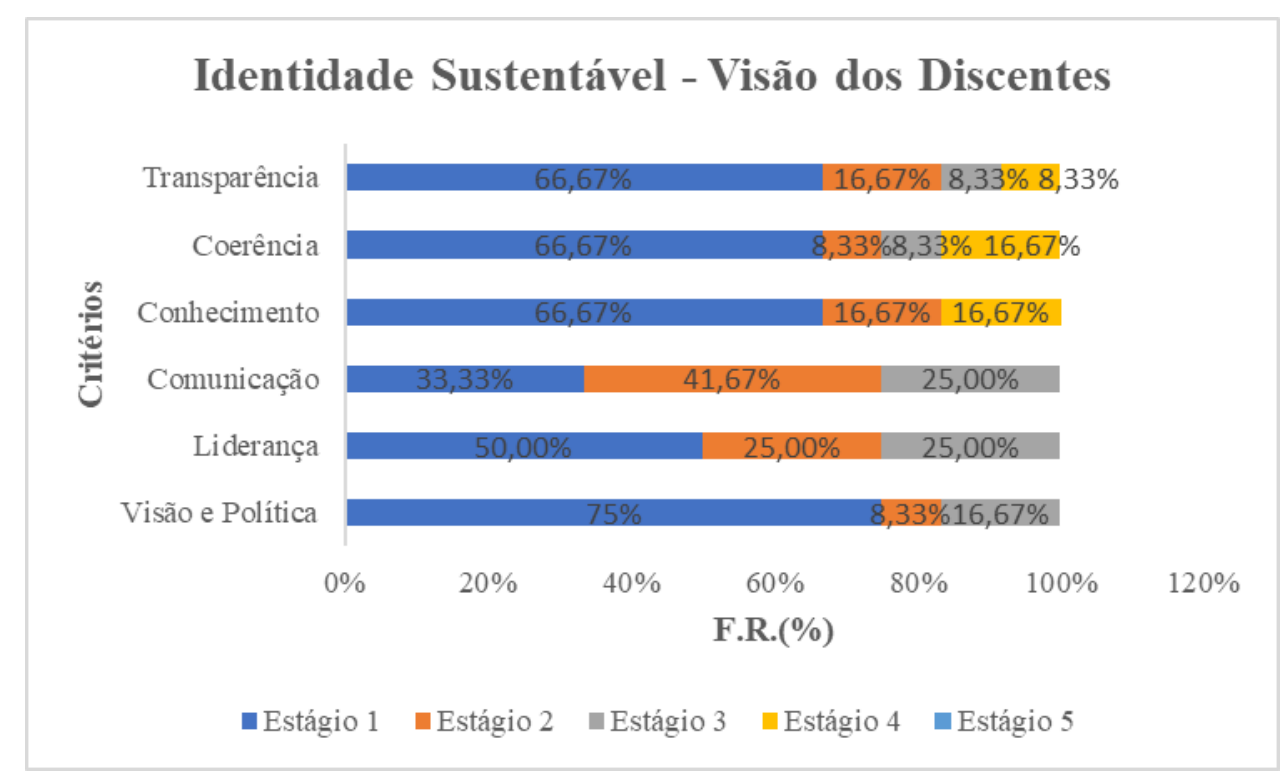

Fonte: Dados da pesquisa

De forma geral, os critérios de identidade sustentável da escola Não PRME-Pública, na percepção dos discentes, são avaliados de forma diferente da dos docentes desta escola. Dos seis critérios, não há nenhum avaliado em menos de três estágios. Os critérios de transparência e de coerência são desenvolvidos em quatro estágios e os outros quatro são avaliados em três estágios. Assim sendo, a identidade sustentável da escola é mais desenvolvida na percepção dos discentes do que na dos docentes desta escola, resultado como constatado nas escolas signatárias, em que as atividades extracurriculares podem não ser suficientes para formação de capacidades e as práticas dos negócios necessários à empresa (CABRERA, 2014).

O critério transparência e coerência, na visão dos discentes, possui maior frequência de ocorrência das respostas no primeiro estágio (66\%). Isto significa que a escola, quando requerida, disponibiliza as informações, e que a concepção e implementação das ações ocorrem de forma participativa. Assim, há o fortalecimento da gestão para as atividades internas, sobressaindo o estágio 2 no critério transparência, o que expressa a integração entre os departamentos da escola, e o estágio 4 no critério coerência, revelando a disponibilidade dos relatórios sobre a gestão responsável nos relatórios anuais.

Continuando com a relevância no estágio 1, o critério conhecimento reforça a tendência de que as atividades dependem das iniciativas individuais, com $66 \%$ das respostas 
dos discentes entrevistados, onde esses elementos mantêm contatos com os centros de especialização. Há um plano de execução destas atividades, onde a escola disponibiliza a infraestrutura, estágio 2, o que permite o desenvolvimento pessoal sobre a sustentabilidade, estágio 3.

A comunicação, que teoricamente permite o fortalecimento da visão da escola sobre as suas atividades nos ambientes internos e externos, para $41 \%$ dos discentes entrevistados, ocorre, principalmente, nas pautas das reuniões e em documentos (estágio 2). Por conseguinte, os membros da equipe passam a ser informados, de acordo com $33 \%$ das respostas, no estágio 1 , e ocorre de forma estruturada, para $25 \%$ dos entrevistados, no estágio 3.

A despeito das proporções de respostas serem diferentes, a liderança e a visão e política como critérios de identidade da escola reforçam a tendência do desenvolvimento da gestão responsável no nível micro (estágio 1). Assim, a liderança visa os membros da equipe, principalmente, e no aspecto visão e política estrutura-se de forma vertical, instituindo-se de cima para baixo, com pequena participação dos seus membros, conforme admitem $16 \%$ dos entrevistados.

No geral, também se pode inferir que para os discentes desta escola, não signatária do PRME, os seis critérios de identidade sustentável da escola mostram a relevância do ambiente interno na sua imagem.

Mesmo assim, ao comparar esta tendência com as respostas dos docentes desta mesma escola, constata-se que a percepção dos discentes sobre a identidade sustentável da escola é mais desenvolvida do que a percepção dos docentes. Entretanto, não se aproxima do que consta das proposições do PRME, como quadro de referência para a mudança dos papeis das escolas de negócio. Por exemplo, enquanto a gestão responsável é avaliada pela realização das atividades nos referidos critérios, se essas atividades se restringem apenas ao ambiente interno, a extensão da gestão responsável para o ambiente externo, conforme a proposição do PRME, requer outros componentes teóricos e ações de intervenções que ultrapassam o ambiente interno da instituição. Nota-se que esta proposição difere das sugestões sobre as mudanças nas organizações, empregando estratégias para a incorporação do PRME no seu ambiente interno (HIND; WILSON; LENSSEN, 2009; HARGREAVES; FINK, 2003; GONÇALVES-DIAS; HERRERA; CRUZ, 2013; EDWARDS, 2013; VIEIRA, 2014). 
O que se destaca, até então, é que esta constatação não ocorre apenas em relação a esta escola, não signatária do PRME. Pelo contrário, ela também se verifica, pelos dados analisados, nas escolas pública e privada, signatárias do PRME. Sob o pressuposto de fundamentar esta inferência dos dados analisados até então, o Quadro 14 apresenta os segmentos do PPC desta escola pública, não signatária do PRME, bem como a descrição de cada um deles.

\section{Quadro 14 - PPC da Escola Não PRME-Pública: Segmentos e descrição}

\begin{tabular}{|c|c|}
\hline Perfil do egresso & $\begin{array}{l}\text { O perfil do egresso do curso de Administração descreve um profissional de formação } \\
\text { técnico-científica específica, com visão sistêmica, capacidade de integração e inovação } \\
\text { e, ainda, consciente de suas responsabilidades sociais e valores éticos. Para atuar } \\
\text { profissionalmente e desenvolver atividades próprias do administrador, o egresso deve } \\
\text { possuir uma visão estratégica sobre as necessidades, oportunidades e potencialidades } \\
\text { das organizações. Para tanto: } \\
\text { - compreender, processar e comunicar com eficiência informações; } \\
\text { - possuir raciocínio analítico e crítico; } \\
\text { - possuir iniciativa e saber técnico para, eticamente, julgar, escolher, decidir e mobilizar os } \\
\text { recursos a ele destinados; } \\
\text { - analisar o contexto das organizações para identificar, antecipar, promover e } \\
\text { implementar ações e mudanças; } \\
\text { - atuar em equipe interdisciplinar; } \\
\text { - compreender a necessidade do contínuo aperfeiçoamento profissional e do } \\
\text { desenvolvimento da autoaprendizagem; } \\
\text { - ter autonomia intelectual para assimilar, adaptar-se e atuar em situações contingenciais e } \\
\text { adversas; } \\
\text { - compreender processos, tomar decisões e resolver problemas no âmbito das } \\
\text { organizações, com base em parâmetros relevantes para a sociedade e para a promoção } \\
\text { da qualidade de vida e a preservação do ambiente; } \\
\text { - refletir e compreender a heterogeneidade das demandas sociais; } \\
\text {-analisar o contexto para identificar, antecipar, promover e implementar ações e } \\
\text { mudanças em organizações de serviço, industriais, comerciais e agroindustriais. }\end{array}$ \\
\hline Objetivos do curso & $\begin{array}{l}\text { O curso de Administração apresenta como objetivo geral formar profissionais capazes } \\
\text { de promover o desenvolvimento das organizações e da comunidade, valorizando, como } \\
\text { princípios norteadores de suas atividades, a ética, o ser humano e a sensibilidade para } \\
\text { questões sociais e ambientais, necessárias ao mundo organizacional. }\end{array}$ \\
\hline $\begin{array}{l}\text { Diretrizes/Metodologias } \\
\text { de ensino e } \\
\text { aprendizagem }\end{array}$ & $\begin{array}{l}\text { Incorpora a noção de competência como a capacidade, esperada do aluno, a ser } \\
\text { formado em Administração, mobilizar saberes e conhecimentos para agir com } \\
\text { pertinência em situações de trabalho marcadas pela incerteza, fluidez e mudanças } \\
\text { aceleradas, signos da sociedade contemporânea. } \\
\text { Oferta de atividades (disciplinas optativas, atividades extraclasse, projetos e seminários } \\
\text { de pesquisa e atividades de envolvimento com a comunidade), que criam } \\
\text { oportunidades de aprendizagem e, colocam o aluno frente a determinadas situações e } \\
\text { exigem a mobilização de conhecimentos e saberes capazes de orientar a sua ação } \\
\text { profissional. Esta estratégia possibilita atender a interesses diversificados dos alunos e } \\
\text { permite tratar de modo particular as necessidades de aprendizagens. Desta forma, é } \\
\text { possível direcionar a ação educacional para atender às expectativas e aos interesses dos } \\
\text { alunos, uma vez que a noção de competência direciona para um tratamento } \\
\text { individualizado do processo de aprendizagem. } \\
\text { Os conteúdos de Formação Básica, Profissional e Estudos de Métodos Quantitativos e } \\
\text { suas Tecnologias serão abordados de modo a permitir aos alunos perceberem a inter- } \\
\text { relação com as situações profissionais em que são utilizados. Isto indica que cada }\end{array}$ \\
\hline
\end{tabular}




\begin{tabular}{|l|l|}
\hline \multirow{5}{*}{ Disciplinas curriculares } & $\begin{array}{l}\text { professor organizará situações de aprendizagem em torno da noção de situação- } \\
\text { problema, adequadas a cada disciplina. O uso desta noção, como recurso } \\
\text { metodológico, tem por finalidade construir mediações entre a situação escolar e a } \\
\text { situação de trabalho engendrando, como toda prática, aprendizagens baseadas na } \\
\text { experiência e não apenas na assimilação direta de conceitos. }\end{array}$ \\
& $\begin{array}{l}\text { Introdução à Administração, Introdução à Economia, Filosofia e Ética, Introdução à } \\
\text { Informática, Matemática I, Fundamento Antropológicos e Políticos, Introdução à }\end{array}$ \\
& Contabilidade, Informática Aplicada, Sociologia, Teorias de Administração I, Teoria \\
& Geral do Estado, Matemática II, Instituições de Direito, Matemática II, Instituições de \\
& Direito, Estatística I, Análise de Balanço, Teorias de Administração II, Economia \\
Brasileira, Direito I, Estatística II, Pesquisa Operacional, Administração Financeira I, & \\
& Psicologia, \\
Matemática Financeira, Direito II, Administração da Produção e Operação I, \\
Administração Financeira II, Metodologia Científica, Contabilidade de Custos, \\
Administração de Recursos Humanos I, Administração de Materiais e Logística I, \\
Economia de Empresa, Administração da Produção e Operação II, Administração de \\
Sistemas de Informação, Estratégia Empresarial, Administração de Materiais e \\
Logística II, Administração Mercadológica I, Administração de Recursos Humanos II, \\
Projeto de Pesquisa, Gestão da Qualidade, Administração Mercadológica II, \\
Planejamento Estratégico, Tópicos Especiais de Administração, Seminário de Pesquisa \\
I, Desenvolvimento da Administração de Produtos, Elaboração da Análise de Projetos, \\
Jogos de Empresa, Seminário de Pesquisa II, Estágio Curricular Obrigatório e TCC. \\
\hline
\end{tabular}

Fonte: Elaborado pela autora

Esta escola pública não signatária do PRME apresenta descrições dos segmentos do PPC que se assemelham aos PRME. Por exemplo, o perfil do egresso, além da ênfase sobre a formação técnica, integra as inovações às responsabilidades sociais e valores éticos, sob o propósito de desenvolver as organizações e as comunidades. Nos objetivos há ainda a ênfase sobre a ética, o ser humano e as questões sociais e ambientais como norteadores das intervenções. Para tanto, uma das diretrizes do ensino/aprendizagem está na oferta de disciplinas optativas, nas atividades extraclasses, nos projetos e seminários de pesquisa que envolvem as comunidades, os quais expressam uma forma de adequação ao PRME, a despeito de ser uma escola não signatária. O interessante é que esta diretriz, sob a forma de disciplinas optativas e de atividades extraclasses, complementa a grade de disciplinas científico-técnicas do programa de formação dos alunos. Portanto, a mudança deste curso, tendo o PRME como referência, poderia ocorrer sob outro formato. Isto é, ela é induzida pelos interesses dos docentes e discentes em se apropriarem das novas demandas da sociedade sobre a sustentabilidade, contando com o apoio da instituição, entretanto, ao analisar as disciplinas que constam na matriz curricular desta escola, ao longo dos 8 períodos do curso, verifica-se que não é ofertada nenhuma disciplina com conteúdos voltados para a sustentabilidade. Devese considerar que essa constatação pode fortalecer a continuidade das investigações sobre a revisão da grade curricular e da educação como instrumento de formação de uma gestão 
responsável (EDWARDS, 2014; MASETTO, 2012; SNELSON-POWELL; GROSVOLD; MILLINGTON, 2016).

Essas inferências podem ser corroboradas pelas análises realizadas a partir do software Iramuteq. Na caracterização do PPC desta escola não signatária, identificou-se 514 ocorrências de 296 palavras. Do total de palavras, 77,36\% são hapax, ou seja, palavras que aparecem apenas uma vez no texto. O Gráfico 9, representado pelo diagrama de Zipf, mostra o comportamento da ocorrência das palavras no texto, considerando a ocorrência do número de palavras, na horizontal, e as frequências de ocorrência na vertical.

Gráfico 9 - Comportamento da ocorrência das palavras - Escola Não PRME- Pública

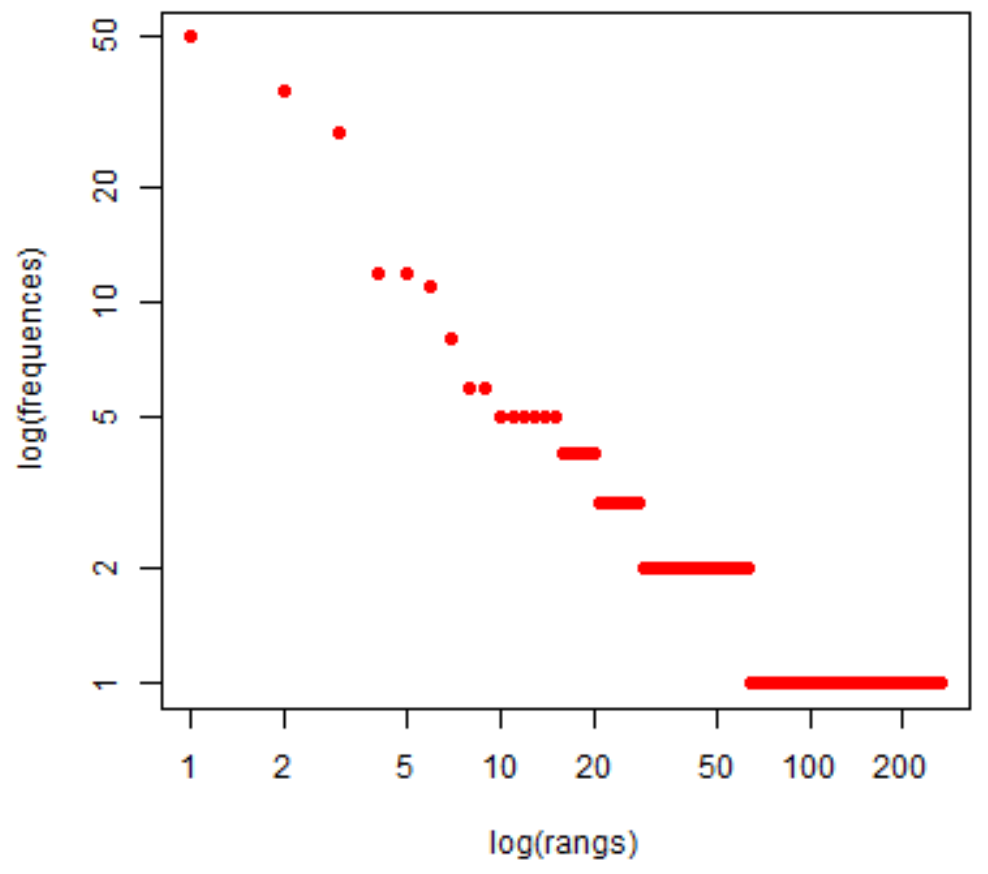

Fonte: Dados da pesquisa

De acordo com o Gráfico 9, a concentração de palavras está entre aquelas que ocorrem até quatro vezes, sendo que o maior número de palavras ocorre apenas uma vez. Pode-se identificar que existem mais de 60 palavras que ocorrem apenas uma vez, ou seja, possuem uma frequência baixa de ocorrência. Por outro lado, há um número pequeno de palavras que ocorrem mais de 20 vezes, possuindo uma frequência alta de ocorrência.

Enquanto o primeiro passo desta análise é identificar as frequências de ocorrências das palavras, o segundo está na identificação destas palavras. Para tanto, a Figura 5 
complementa a compreensão da distribuição de palavras no PCC, pois ela apresenta a nuvem de palavras de acordo com a frequência com que elas aparecem no PPC.

Figura 5 - Nuvem de palavras - Escola Não PRME - Pública

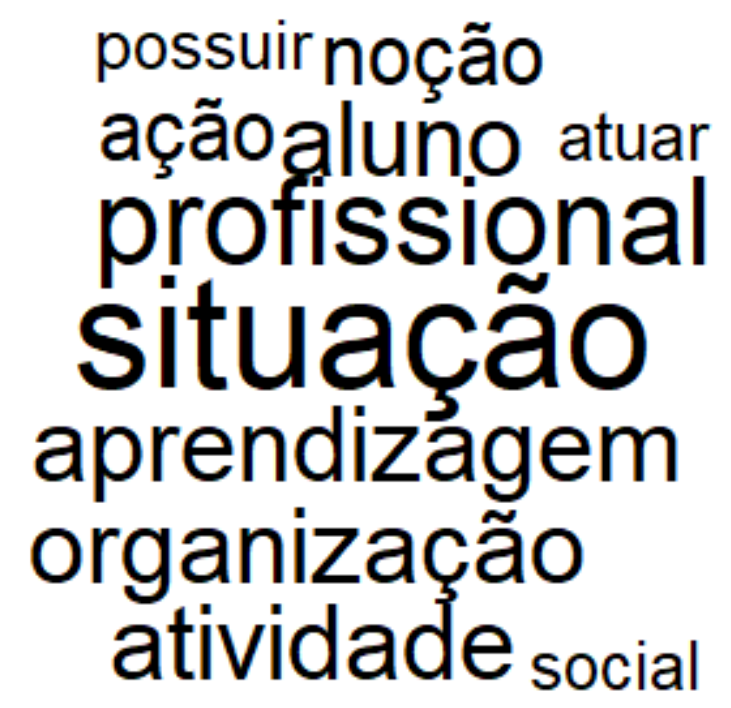

Fonte: Dados da pesquisa

Pode-se observar que a palavra que aparece com maior frequência é "situação", com frequência 8; "profissional", com frequência 6; "aluno", "aprendizagem", "atividade" e "organização", com frequência 5; e "ação", "compreender" e "noção", com frequência 4. As demais aparecem com uma frequência inferior a 3. Teoricamente, há a coerência entre a proposição técnica e profissional constante do PPC e a Figura 3, uma vez que, como identificado no Quadro 11, são as atividades extraclasses que aproximam esta escola do PRME e dos critérios de identidade de sustentabilidade da escola apresentados pelo questionário AISHE. Portanto, ao mesmo tempo em que se constata que o PPC não orienta a formação dos alunos sob os propósitos do AISHE e do PRME, ele permite, pelas atividades extraclasses, que atividades possam ser concebidas e realizadas sob aqueles propósitos.

A princípio, a inferência possível sobre esses dados é que os desacoplamentos entre o PCC e os critérios do AISHE e o PRME se constituem na principal lacuna a ser transposta, para que a escola seja inserida nos propósitos da nova educação responsável nas escolas de negócios. 


\subsubsection{Escola Não PRME - Privada}

Os resultados desta escola, não signatária, estão apresentados no Gráfico 10. Foram entrevistados 11 docentes do curso de administração. Pelo Gráfico 10, observa-se que as percepções dos respondentes sobre a identidade sustentável da escola se concentram no primeiro estágio dos seguintes critérios: coerência, conhecimento, comunicação e visão e política. O critério transparência se apresenta como mais relevante no estágio 2 e o critério liderança é tão relevante para o estágio 1 quanto para o estágio 2, como $45 \%$ das respostas dos docentes participantes da pesquisa, respectivamente.

Gráfico 10 - Identidade sustentável da escola Não PRME-Privada para os docentes

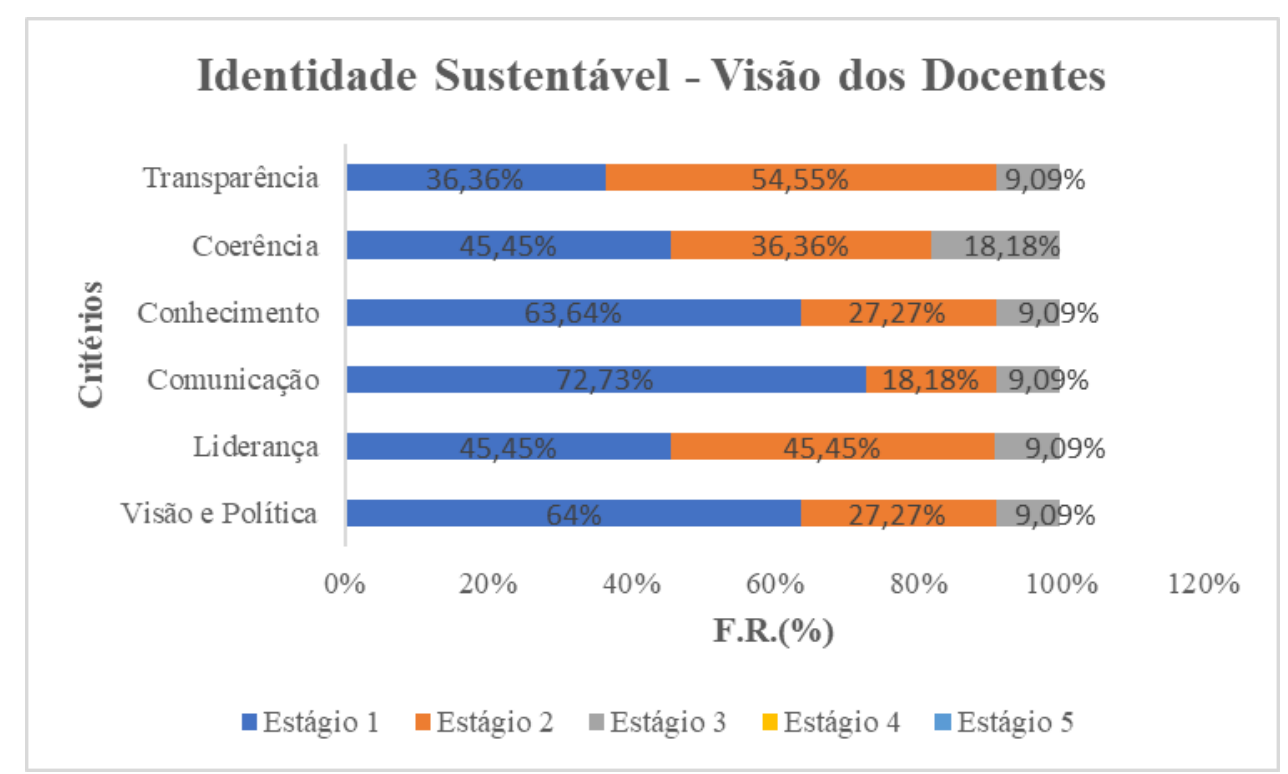

Fonte: Dados da pesquisa

No estágio 1 há as seguintes interpretações para os referidos critérios. Coerência reflete que as ações de concepção e implementação ocorrem de forma participativa na execução dos múltiplos papeis da escola. Por sua vez, o conhecimento depende das iniciativas individuais, de forma que os membros da equipe são comunicados sobre essas atividades, e no que concerne a visão e política, que é determinada a partir da relação vertical, de cima para baixo.

Sob este contexto, a transparência está em apresentar as informações, de forma estruturada, aos membros da equipe, alunos e funcionários e que a liderança ocorre, por conseguinte, em relação a esses elementos da escola. No geral, tem-se a configuração do 
módulo identidade fundamentado pelos seis critérios, mas desenvolvidos, especificamente, no seu ambiente interno. De outra forma, a visão sobre a identidade sustentável da escola é pouco desenvolvida, apesar da constatação da ocorrência de poucos percentuais de respostas no estágio intermediário. Se esta é uma tendência comum aos demais docentes das escolas signatárias e não signatárias, como constatado até então, pode-se inferir que, no geral, a formação destes docentes esteja concentrada nas competências técnicas das áreas dos cursos de Administração, fundamentada pela ênfase em pesquisa e não no ensino (VIEIRA, 2014), valorizando, a Universidade pelo papel de promover a construção do conhecimento (FIGUEIREDO; GERRA; CARLETO, 2014).

Outro componente da análise sobre a identidade sustentável da escola se refere aos dados coletados sobre os discentes do mesmo curso de administração. São 23 alunos que responderam ao questionário da pesquisa. Os dados sobre a percepção dos discentes sobre os seis critérios de identidade, bem como os respectivos estágios, são apresentados no Gráfico 11.

Gráfico 11 - Identidade sustentável da escola Não PRME-Privada para os discentes

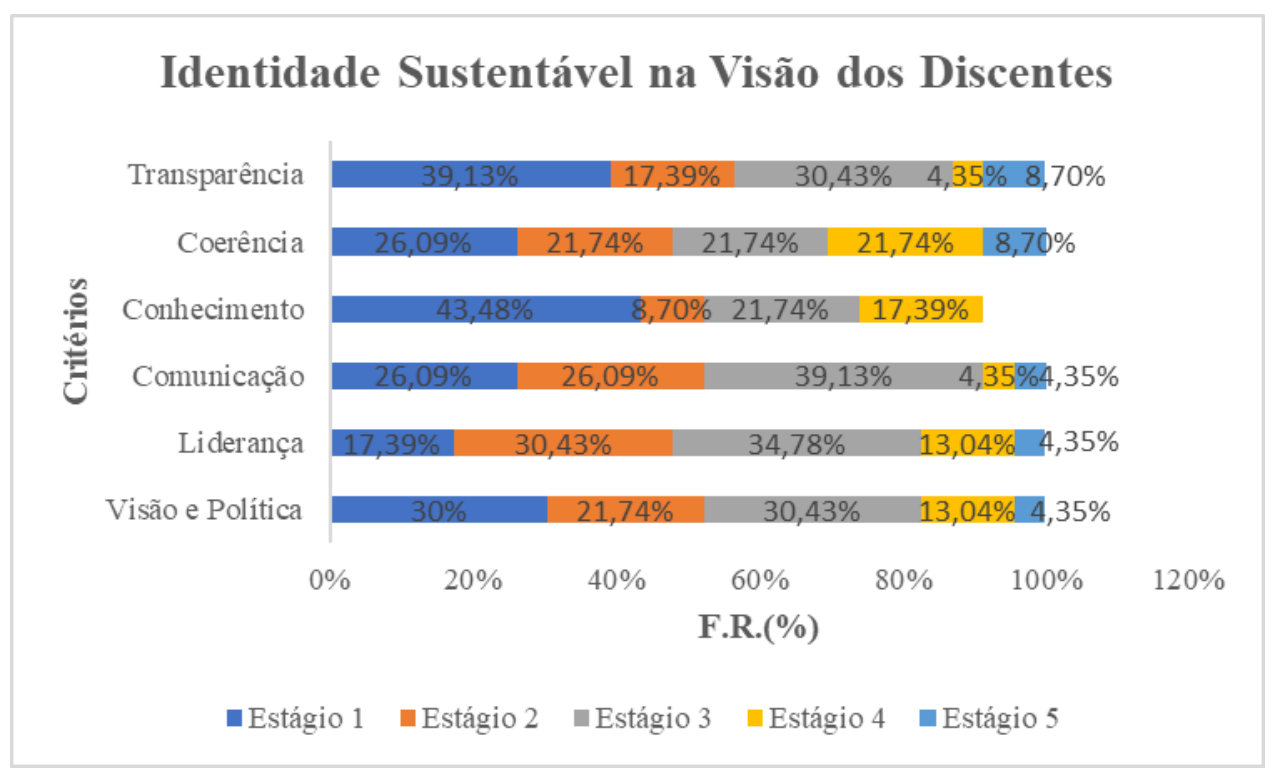

Fonte: Dados da pesquisa

O Gráfico 11 apresenta uma visão de identidade sustentável da escola não encontrada na percepção dos docentes e discentes analisados até então, sejam escolas signatárias ou não signatárias do PRME. Dos seis critérios, apenas o conhecimento não se estende a todos os 
estágios. Nos demais critérios, a visão dos discentes sobre a identidade sustentável da escola se inicia no nível micro, passa pelo intermediário, alcançando o nível macro, orientado pelas cadeias de interações, atingindo o nível da sociedade. A princípio, pode-se inferir que é uma apreensão desenvolvida, da identidade sustentável da escola, evidenciada pela relevância de alguns estágios, nos diferentes critérios.

Enquanto se constata a relevância do estágio 1 nos critérios de transparência, coerência e conhecimento, os critérios comunicação e liderança são destacados pelo estágio 3, e visão e política apresentam uma relevância tanto no estágio 1 quanto no estágio 3. Esses critérios são desenvolvidos nos cinco estágios, com percentuais de respostas nos estágios 4 e 5 , mas que também evidenciam o desenvolvimento dos critérios até o ambiente externo da escola.

Esta constatação contrasta com a encontrada entre os docentes da mesma escola, onde a concentração de respostas está nos estágios que demonstram a gestão responsável da escola em nível local. Em outros termos, pode-se inferir que a identidade sustentável da escola, na percepção dos discentes, é desenvolvida. Deve-se considerar que, apesar de a escola não ser signatária do PRME, pode-se inferir que as suas atividades voltadas para a visão sustentável da escola, estão, de certa forma, implícitas nas orientações gerais estabelecidas no PRME sobre a gestão responsável. Como constatado em relação aos demais discentes das escolas signatárias e não signatárias, pode-se inferir que a formação é complementada pelas atividades de extensão universitária (FARIAS, 2014), sob propósito de incorporar as demandas da sociedade nas intervenções das escolas (SÁENZ, 2014). Contudo, permanece a dúvida se estas práticas serão adequadas às empresas (CABRERA, 2014) ou se as empresas devem desenhar os seus próprios modelos de liderança (LILI; XIAOXIAO, 2009).

Complementando a análise desta escola privada, não signatária do PRME, o Quadro 15 apresenta os segmentos do PPC, bem como a suas descrições, as quais se constituíram em referências para as análises do software Iramuteq. Na descrição dos quatro segmentos, constata-se a ênfase profissional, técnica e científica na formação dos alunos. Há uma dimensão dos objetivos do curso que destaca o ajuste contínuo do programa às mudanças, tanto em relação às inovações na área quanto às relativas ao desenvolvimento sustentável. Pode-se supor, portanto, que esta disposição permitiu introduzir uma disciplina denominada "Responsabilidade Social e Sustentabilidade", oferecida no $7^{\circ}$ período, mas que segue as diretrizes de ensino/aprendizagem pelos conteúdos técnico/científicos das disciplinas do curso. 
Quadro 15 - PPC da Escola Não PRME-Privada: Segmentos e descrição

\begin{tabular}{|c|c|}
\hline Perfil do egresso & $\begin{array}{l}\text { O egresso do Curso de Administração estará apto a compreender as questões } \\
\text { científicas, técnicas, sociais e econômicas da produção e de seu gerenciamento, } \\
\text { observados níveis graduais do processo de tomada de decisão, bem como para } \\
\text { desenvolver gerenciamento qualitativo e adequado, revelando a assimilação de novas } \\
\text { informações e apresentando flexibilidade intelectual e adaptabilidade contextualizada } \\
\text { no trato de situações diversas, presentes ou emergentes, nos vários segmentos do } \\
\text { campo de atuação do administrador. }\end{array}$ \\
\hline Objetivos do curso & $\begin{array}{l}\text { O Curso de Bacharelado em Administração tem como objetivo desenvolver no aluno } \\
\text { competências e habilidades gerenciais e empreendedoras que permitam a formação de } \\
\text { um profissional empreendedor e gerenciador de negócios dotado de visão crítica e } \\
\text { reflexiva, com plenas condições de compreender a complexidade e as contradições que } \\
\text { delineiam a dinâmica organizacional do mercado e da sociedade, além de criar } \\
\text { condições para um ajustamento contínuo às mudanças, exigência primordial no mundo } \\
\text { globalizado, valorizando a inovação e o desenvolvimento sustentável, pautado em uma } \\
\text { postura ética. }\end{array}$ \\
\hline $\begin{array}{l}\text { Diretrizes/Metodologias } \\
\text { de ensino e } \\
\text { aprendizagem }\end{array}$ & $\begin{array}{l}\text { Pretende-se que as competências profissionais em formação sejam construídas } \\
\text { processualmente, o que implica na adoção de métodos de ensino que envolvam práticas } \\
\text { de ação/reflexão/ação. Nesse sentido, a concepção curricular privilegia uma abordagem } \\
\text { metodológica que traz para o lugar central da formação as práticas e a reflexão sobre } \\
\text { elas. } \\
\text { Privilegia-se a adoção de metodologias ativas, coerentes com os objetivos e os } \\
\text { conteúdos de ensino e que considerem a experiência concreta do estudante como ponto } \\
\text { de partida do trabalho pedagógico. } \\
\text { Busca-se promover ações pedagógicas que articulem os saberes e as práticas, } \\
\text { vinculando-os aos ideais da ética, da responsabilidade, da cidadania, do respeito ao } \\
\text { meio ambiente, da solidariedade e do espírito coletivo, e direcionando-as ao } \\
\text { atendimento das necessidades da comunidade regional e local. } \\
\text { O ensino tem sido entendido como um processo que visa associar a construção crítica } \\
\text { ao conhecimento produzido, num processo contínuo e articulado. Assim, ele é } \\
\text { concebido como um processo de investigação do conhecimento, e não como um } \\
\text { processo que se limita à transmissão de conteúdos; como uma prática voltada para a } \\
\text { construção da progressiva autonomia do aluno na busca do domínio científico e } \\
\text { profissional de um determinado campo do conhecimento. }\end{array}$ \\
\hline Disciplinas curriculares & $\begin{array}{l}\text { Fundamentos da Ciências Sociais, Fundamentos de Contabilidade, Fundamentos de } \\
\text { Economia, Fundamentos de Gestão, Fundamentos de Matemática, Língua Portuguesa, } \\
\text { Contabilidade Básica, Filosofia Ética e Cidadania, Legislação Fiscal Trabalhista } \\
\text { Previdenciária, Matemática para Negócios, Psicologia das Organizações, Redação } \\
\text { Técnica, } \\
\text { Gestão Contábil Comercial e Financeira, Gestão de Processos e Serviços, Gestão de } \\
\text { Rotinas Trabalhistas, Introdução à Administração, Matemática Financeira, Cenários } \\
\text { Econômicos e Sociais, Comunicação Organizacional, Contabilidade e Apuração de } \\
\text { Custos, Estatística e Probabilidade, Gestão de Marketing, Novos Negócios e } \\
\text { Empreendedorismo, Competências Gerenciais, Gestão da Cadeia de Suprimentos, } \\
\text { Gestão da Qualidade, Gestão Estratégica de Pessoas, Panorama Econômico, Teoria } \\
\text { Geral da Administração, Análise das Demonstrações Financeiras, Análise de } \\
\text { Investimento, Contabilidade Gerencial, Gerenciamento Orçamentário, Mercado } \\
\text { Financeiro, Responsabilidade Social e Sustentabilidade, Sistemas de Controles } \\
\text { Internos, Administração da Produção e Operações, Administração Estratégica, Estágio } \\
\text { Supervisionado, Pesquisa de Mercado, Práticas Empresariais Informatizadas, Teoria } \\
\text { dos Jogos, Gerenciamento de Projetos, Negociação Empresarial, Pesquisa e } \\
\text { desenvolvimento, Pesquisa Operacional, Práticas de Pesquisa da Administração. }\end{array}$ \\
\hline
\end{tabular}

Fonte: Elaborado pela autora 
$\mathrm{Na}$ análise dos segmentos e de suas descrições no PPC, a análise estatística constatou 399 ocorrências de 244 palavras. Do total de palavras, 81,56\% são hapax, ou seja, palavras que aparecem apenas uma vez no texto. O Gráfico 12, representado pelo diagrama de Zipf, mostra o comportamento da ocorrência das palavras no texto, considerando a ocorrência do número de palavras, na horizontal, e as frequências de ocorrência na vertical.

Gráfico 12 - Comportamento da ocorrência das palavras - Escola Não PRME-Privada

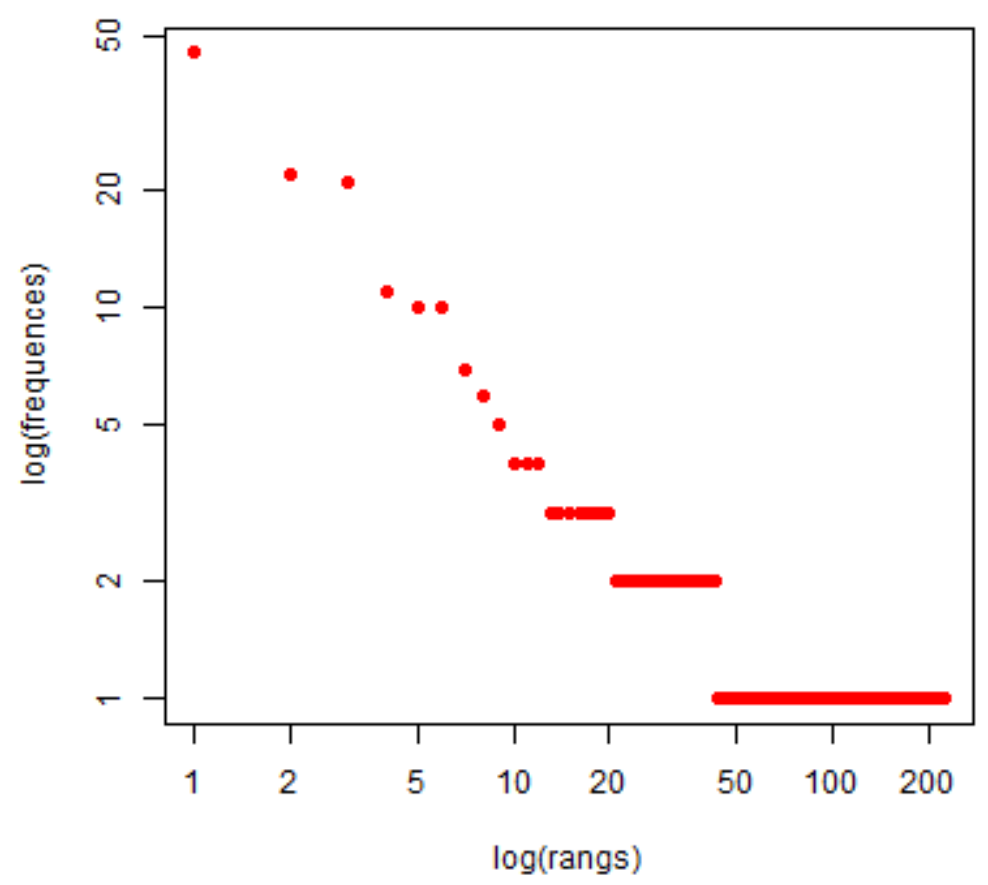

Fonte: Dados da pesquisa

De acordo com o Gráfico 12, a concentração de palavras está entre aquelas que ocorrem até quatro vezes, sendo que o maior número de palavras ocorre apenas uma vez. Pode-se identificar que existem mais de 50 palavras que ocorrem apenas uma vez, ou seja, possuem uma frequência baixa. Por outro lado, há um número pequenos de palavras que ocorrem mais de 10 vezes, possuindo uma frequência alta de ocorrência.

Após esta constatação, é possível identificar quais são as palavras que mais expressam os conteúdos do PPC. Para tanto, a Figura 6 apresenta a nuvem de palavras de acordo com a frequência com que elas aparecem no Plano Pedagógico do Curso. 
Figura 6 - Nuvem de palavras - Escola Não PRME - Privada

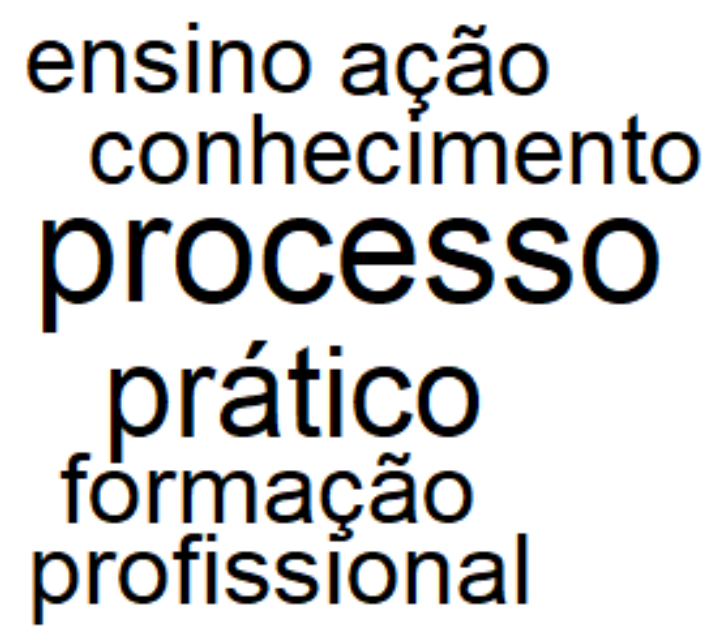

Fonte: Dados da pesquisa

Pode-se observar que a palavra que aparece com maior frequência é "processo", com frequência 5, e "prático", com frequência 4, ocorrendo as demais com frequência 3. Considerando a ênfase do PPC na formação técnica e científica da área da Administração, os termos processo e prático ilustram dinâmicas associadas àquela formação, que decorrem do ensino sobre pesquisa de mercado, práticas empresariais informatizadas, teoria dos jogos, gerenciamento de projetos, negociação empresarial, pesquisa e desenvolvimento, pesquisa operacional e práticas de pesquisa da administração. É o ensino fundamentado pela competência técnica (VIEIRA, 2014), contrastando o PRME como modelo de gestão educacional (GOLEMANN et al.,2014). Em conformidade com os resultados anteriormente apresentados, constata-se que a redefinição da gestão educacional pelo PRME (ALCARAZ; THIRUVATTAL, 2010), ainda se constitui em uma questão aberta (STACHOWICZSTANUSCH, 2011).

A mesma interpretação se aplica à ocorrência da palavra "conhecimento". Mesmo não tendo uma frequência significativa no PPC, e sendo um dos critérios do módulo identidade do AISHE, na promoção de uma identidade sustentável, o conhecimento é condicionado técnica e cientificamente à área do curso e restrito, principalmente, às iniciativas individuais dos docentes. Em relação aos discentes, o conhecimento se concentra nas atividades que eles desenvolvem, mas se estende, talvez pelas práticas, com contatos regulares à cadeia de atores, externo ao ambiente da instituição. O que deve ser destacado, tanto nesta fundamentação quanto nas anteriores, é a relevância do software Iramuteq, na análise dos conteúdos, 
complementando o instrumento AISHE e o PRME, como referência para a introdução de mudanças nas escolas de negócio.

\subsection{Análise da Identidade Sustentável entre as Escolas}

A análise comparativa é sobre a identidade sustentável das escolas investigadas. O quadro de referência instrumental para esta análise é o AISHE e o software Iramuteq. Enquanto o primeiro permite construir tabelas comparativas considerando os percentuais das respostas sobre os critérios de identidade e os seus estágios nas escolas signatárias e não signatárias, públicas e privadas, envolvendo docentes e discentes da instituição, o segundo complementa esta análise, agregando os vocábulos componentes dos segmentos dos textos dos PPCs das quatro escolas pelo método de classificação hierárquica descendente (CDH).

Em relação aos docentes das escolas pública e privada, signatárias do PRME, constatase, pela Tabela 2, que a valorização dos critérios de identidade está no estágio 1 . As exceções são os critérios de coerência e conhecimento no estágio 2 para os docentes da escola pública, e liderança no estágio 2, para os docentes da escola privada. Não obstante, estes resultados revelam que as escolas signatárias não se diferenciam em relação aos critérios de identidade pelo fato de serem públicas e privadas.

Para ambas as escolas, o foco é o direcionamento das atividades de sustentabilidade para a gestão interna da escola, onde sobressai a ênfase sobre a incorporação da temática ambiental e da sustentabilidade na universidade (FARIAS, 2014). Especificamente, a escola possui a visão e política implicita nos documentos, os quais são disponibilizados quando requeridos. Além disso, há a interação entre os membros da equipe, os estudantes e os funcionários, retratando que a liderança ocorre entre estes elementos, o que resulta em algumas atividades de intervenções da equipe.

Entre os discentes, os da escola "PRME-Pública" tendem a valorizar o estágio 2, em quatro dos seis critérios; o estágio 3 em três critérios e o estágio 4 em um critério. Nota-se que estes discentes apresentam a avaliação dispersa, dos critérios, nos diferentes estágios. O que se destaca é a inclusão do estágio 4 no critério comunicação, além de outros critérios serem identificados por proporções percentuais relativamente pequenas. Assim, há o reforço das atividades da escola pública sobre a interação com os stakeholders, em termos de disponibilidade de conhecimentos, há o envolvimento da gestão no incentivo das interações, 
especialmente com estratégias de médio e longo prazo, que são comunicadas às partes interessadas, disponibilizando os relatórios e as publicações em Tanrevistas científicas. 
Tabela 2 - Identidade sustentável, em porcentagem, para os docentes e discentes das escolas investigadas

\begin{tabular}{|c|c|c|c|c|c|c|c|c|c|c|c|c|c|c|c|c|c|c|c|c|c|c|c|c|c|}
\hline & & \multicolumn{12}{|c|}{ ESCOLAS SIGNATÁRIAS DO PRME } & \multicolumn{12}{|c|}{ ESCOLAS NÃO SIGNATÁRIAS DO PRME } \\
\hline & & \multicolumn{6}{|c|}{ PÚBLICA } & \multicolumn{6}{|c|}{$\begin{array}{l}\text { PRIVADA } \\
\end{array}$} & \multicolumn{6}{|c|}{ PÚBLICA } & \multicolumn{6}{|c|}{$\begin{array}{l}\text { PRIVADA } \\
\end{array}$} \\
\hline & & $\mathrm{T}$ & $\mathrm{Co}$ & $\mathrm{Cn}$ & $\mathrm{Cm}$ & $\mathrm{L}$ & VP & $\mathrm{T}$ & $\mathrm{Co}$ & $\mathrm{Cn}$ & $\mathrm{Cm}$ & $\mathrm{L}$ & VP & $\mathrm{T}$ & Co & $\mathrm{Cn}$ & $\mathrm{Cm}$ & $\mathrm{L}$ & VP & $\mathrm{T}$ & $\mathrm{Co}$ & $\mathrm{Cn}$ & $\mathrm{Cm}$ & $\mathrm{L}$ & VP \\
\hline \multirow{7}{*}{ Dc } & E1 & 63 & 37 & 31 & 47 & 47 & 58 & 58 & 50 & 67 & 42 & 33 & 58 & 75 & 25 & 62 & 25 & 62 & 25 & 36 & 45 & 63 & 72 & 45 & 64 \\
\hline & E2 & 16 & 53 & 53 & 42 & 37 & 21 & 25 & 33 & 8 & 33 & 42 & 8 & 25 & 37 & 37 & 62 & 12 & 50 & 54 & 36 & 27 & 18 & 45 & 27 \\
\hline & E3 & 16 & 5 & 5 & 5 & 5 & 16 & 17 & - & 17 & - & 25 & 8 & - & 12 & - & - & 25 & 12 & 9 & 18 & 9 & 9 & 9 & 9 \\
\hline & E4 & 5 & 5 & 10 & 5 & 10 & 5 & - & 8 & - & 17 & - & 25 & - & 12 & - & 12 & - & - & - & - & - & - & - & - \\
\hline & E5 & - & - & - & - & - & - & & & & & & & - & - & - & - & - & 12 & - & - & - & - & - & - \\
\hline & & \multicolumn{6}{|c|}{ PÚBLICA } & \multicolumn{6}{|c|}{ PRIVADA } & \multicolumn{6}{|c|}{ PÚBLICA } & \multicolumn{6}{|c|}{ PRIVADA } \\
\hline & & $\mathrm{T}$ & $\mathrm{Co}$ & $\mathrm{Cn}$ & $\mathrm{Cm}$ & $\mathrm{L}$ & VP & $\mathrm{T}$ & $\mathrm{Co}$ & $\mathrm{Cn}$ & $\mathrm{Cm}$ & $\mathrm{L}$ & VP & $\mathrm{T}$ & $\mathrm{Co}$ & $\mathrm{Cn}$ & $\mathrm{Cm}$ & $\mathrm{L}$ & VP & $\mathrm{T}$ & $\mathrm{Co}$ & $\mathrm{Cn}$ & $\mathrm{Cm}$ & $\mathrm{L}$ & VP \\
\hline \multirow{5}{*}{ Ds } & E1 & 27 & 9 & 36 & 27 & 27 & - & 44 & 26 & 37 & 33 & 41 & 30 & 66 & 66 & 66 & 33 & 50 & 75 & 39 & 26 & 43 & 26 & 17 & 30 \\
\hline & E2 & 36 & 54 & 18 & 27 & 27 & 36 & 33 & 19 & 22 & 52 & 19 & 41 & 16 & 8 & 16 & 41 & 25 & 8 & 17 & 21 & 8 & 26 & 30 & 21 \\
\hline & E3 & 9 & 18 & 45 & 18 & 45 & 36 & 11 & 37 & 11 & 7 & 30 & 19 & 8 & 8 & 16 & 25 & 25 & 16 & 30 & 21 & 21 & 39 & 34 & 30 \\
\hline & E4 & 27 & 9 & - & 27 & - & 18 & 7 & 15 & 22 & 4 & 11 & 11 & 8 & 16 & - & - & - & - & 4 & 21 & 17 & 4 & 13 & 13 \\
\hline & E5 & - & 9 & - & - & - & 9 & 4 & 4 & 7 & 4 & - & - & - & - & - & - & - & - & 8 & 8 & - & 4 & 4 & 4 \\
\hline
\end{tabular}

Fonte: Dados da pesquisa

Legenda:

Dc: Docentes

Ds: Discentes

E: Estágios

T: Transparência

Co: Coerência

$\mathrm{Cn}$ : Conhecimento

$\mathrm{Cm}$ : Comunicação

L: Liderança

VP: Visão e Política 
Comparando com as respostas dos discentes da escola "PRME-Pública", os da escola "PRME-Privada" concentram as respostas nos estágios 1 e 2. Há apenas uma referência ao estágio 3 para o critério coerência na escola privada, signatária do PRME. Isto significa que a escola se envolve com as políticas e ações inerentes às atividades de gestão, educação, pesquisa e contribuição para a sociedade. Em certo sentido, até o estágio 3 identifica-se a concentração das atividades da escola na gestão interna ao ambiente educacional.

Ao comparar docentes e discentes das escolas pública e privada signatárias do PRME nota-se a mesma tendência, na avaliação dos estágios e dos critérios de identidade sustentável da escola. Ou seja, a apreensão de que a identidade se concentra no seu ambiente interno, ambiente este caracterizado por atividades integradas a um processo que envolve a equipe de pesquisa, estudantes e funcionários. Estes elementos delimitam o sistema interno, foco da gestão educacional, onde as mudanças requeridas para as escolas se tornarem signatárias do PRME estão concentradas em componentes isolados do quadro de referência geral da gestão educacional, como a inclusão de disciplinas optativas no currículo escolar ou métodos de ensino aprendizagem.

Em relação às escolas não signatárias, pública e privada, identifica-se uma diferença entre elas, qual seja, enquanto os docentes da escola pública valorizam os estágios 1 e 2 nas respostas aos seis critérios, os da escola privada valorizam o estágio 1 em quatro critérios, apenas o estágio 2 no critério transparência e os estágios 1 e 2 para o critério liderança. Não obstante essa dispersão de respostas, elas enfatizam as atividades de sustentabilidade da escola voltada aos membros da equipe, dependentes das iniciativas individuais etc., sendo estas atividades estendidas aos membros da instituição e aos alunos. Portanto, para os docentes de ambas as escolas não signatárias, a identidade sustentável da escola é relevante apenas para os elementos componentes do ambiente interno a ela, não integrando as atividades sob a gestão do sistema educacional, pois os percentuais atribuídos ao estágio 3 dos critérios são relativamente baixos, em relação aos percentuais atribuídos pelos docentes aos estágios 1 e 2. Esses dados reforçam a proposição sobre a necessidade de apoio para a formação dos docentes na implementação do PRME, especialmente sobre a integração disciplinar na abordagem da sustentabilidade.

Esta constatação suporta o argumento de que ambas as escolas, pelo fato de serem pública ou privada e não signatárias do PRME, não diferem entre si quanto à relevância dos critérios e os seus estágios de desenvolvimento na caracterização da identidade sustentável 
das escolas. Não obstante, pode-se acrescentar que as respostas dos docentes da escola pública também evidenciam que a escola não está isolada do contexto da sociedade. A despeito dos baixos percentuais no estágio 3, da valorização de dois critérios no estágio 4 , e de outro no estágio 5, esta escola se insere com os stakeholders, disponibiliza dados e informações e interage com a rede externa na aquisição de conhecimentos, o que não é constatado em relação à escola privada não signatária do PRME.

Na percepção dos discentes das escolas não signatárias do PRME, identifica-se, pela Tabela 2, que os entrevistados da escola pública atribuem as maiores frequências de ocorrências ao estágio 1, quando comparadas com as respostas dos entrevistados da escola privada. Para a escola "PRME-Pública", os discentes destacam que as informações precisam ser requeridas pelos membros, mas os dados são apresentados em reuniões, sendo que o conhecimento depende das iniciativas individuais, ocorrendo o envolvimento dos discentes, sob a liderança dos membros da equipe, mas com a construção da visão e política de cima para baixo.

Apesar de as respostas dos discentes da escola "Não PRME-Privada" apontarem para a identidade sustentável da escola por alguns critérios citados pelos discentes da escola "Não PRME-Pública”, há a diferença entre eles em relação a três critérios. Isto é, os discentes da escola privada destacam três critérios que são valorizados pelo estágio 3, o que significa que a comunicação é estruturada, a gestão da escola estimula a participação dos discentes e dos funcionários na melhoria da visão, estratégias e na avaliação das atividades da escola. Como consequência, os discentes estão envolvidos no processo de melhoria da visão e política de sustentabilidade.

A despeito desta diferença, constata-se pela Tabela 2 que o foco da perspectiva dos discentes, em ambas as escolas não signatárias do PRME, sobre a identidade sustentável das escolas, é o ambiente interno a ela. Esta tendência corrobora a tendência constatada pelas docentes de ambas as escolas não signatárias do PRME. Além disto, as tendências dos docentes e discentes das escolas públicas e privadas, independentemente de serem signatárias ou não, seguem a mesma tendência em concentrar os maiores percentuais das respostas dos critérios nos estágios 1, 2 e 3. A única exceção é que as respostas dos discentes da escola "PRME-Pública" valorizam o critério comunicação no estágio 4.

Deve-se considerar que os valores percentuais menores, atribuídos aos estágios 4 e 5 , revelam que as atividades voltadas à gestão educacional não estão isoladas do contexto 
socioeconômico e político das instituições. Constata-se este envolvimento, mas não ocorre de forma tão intensa quanto a realização das atividades para o ambiente interno às escolas. Neste sentido, o papel pró-ativo e de excelência da instituição no campo educacional e profissional não é assegurado. Essas tendências podem ser melhor observadas pelos Gráficos 13, 14, 15 e 16, onde pode-se comparar a distribuição das percentagens dos docentes e discente, sobre a compreensão da identidade sustentável, entre os critérios e os respectivos estágios das escolas públicas e privadas, signatárias e não signatárias.

Gráfico 13 - Comparação Docentes - Escolas Signatárias

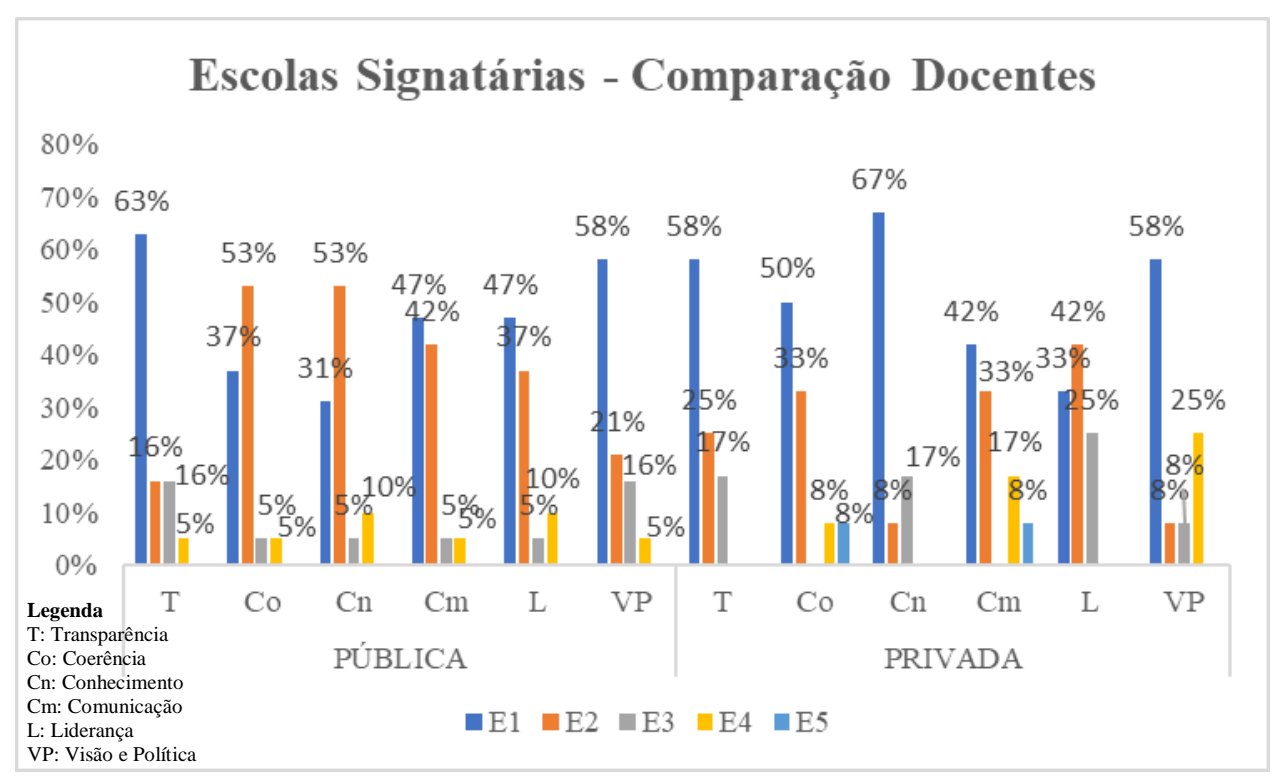

Fonte: Dados da pesquisa

A constatação, pelo Gráfico 13, sobre a não diferença na avaliação da identidade sustentável da escola por parte dos docentes poderia fundamentar proposições sobre as possíveis formações destes docentes. Em conformidade com a revisão de literatura, esta formação deve priorizar trabalho em grupos, inter e multidisciplinares, e por ações interdisciplinares (LEONARDI, 2002), além do desenvolvimento de projetos de pesquisa e de atividades de extensão (TARDIF, 2002). Conceitualmente, o objetivo é a formação dos docentes pela consciência ambiental (EDWARDS, 2013).

Entretanto, ao associar o conteúdo destas formações, como, por exemplo, o de responsabilidade social da organização (SCHRETTLE et al., 2014), com a formação para a apreensão do modelo de gestão do PRME (ONU BRASIL, 2017), há diferenças de conteúdos, pois o modelo PRME é um modelo de gestão educacional e não simplesmente referência à 
inclusão dos componentes ambientais e sociais de sustentabilidade que viabilizam os negócios (SCHRETTLE et al., 2014). É relevante destacar a proposição de que a educação é a ferramenta para a formação da consciência ambiental (EDWARDS, 2013), entretanto, esta consciência privilegia conteúdos associados à exploração dos recursos naturais e não, necessariamente, a gestão educacional.

Pontos críticos tem sido constatado na formação dos docentes, sendo, um deles, a reduzida carga horária da disciplina de metodologia de ensino (ANASTASIOU, 2003; MASETTO, 2012). Outro, é a formação nos programas de pós-graduação, o qual direciona a formação mais para a pesquisa e menos para o ensino (VIEIRA, 2014). No geral, são orientações derivadas das políticas educacionais que definem as diretrizes curriculares para os cursos de licenciatura (PEREIRA, 1999) e da sua revisão que tem permitido criação de programas e planos específicos, como o da educação especial e inclusiva, cursos de aperfeiçoamento, etc. (GARCIA, 2013).

Portanto, a formação dos docentes, em geral e nos cursos de Administração, envolve uma complexidade maior de fatores determinantes. Neste sentido, destaca-se a proposta de inserir os valores sociais, da organização e os ecológicos na gestão das escolas, empregando ações estratégicas (FORRAY; LEIGH, 2012). Nota-se que a ênfase destes autores é sobre a gestão das escolas, o que pode induzir à apreensão do modelo PRME como uma nova visão do papel do administrador na sociedade (CABRERA, 2014). São referências que podem se constituir em orientações para a transformação da gestão educacional (GODEMANN et al., 2014). 
Gráfico 14 - Comparação Discentes - Escolas Signatárias

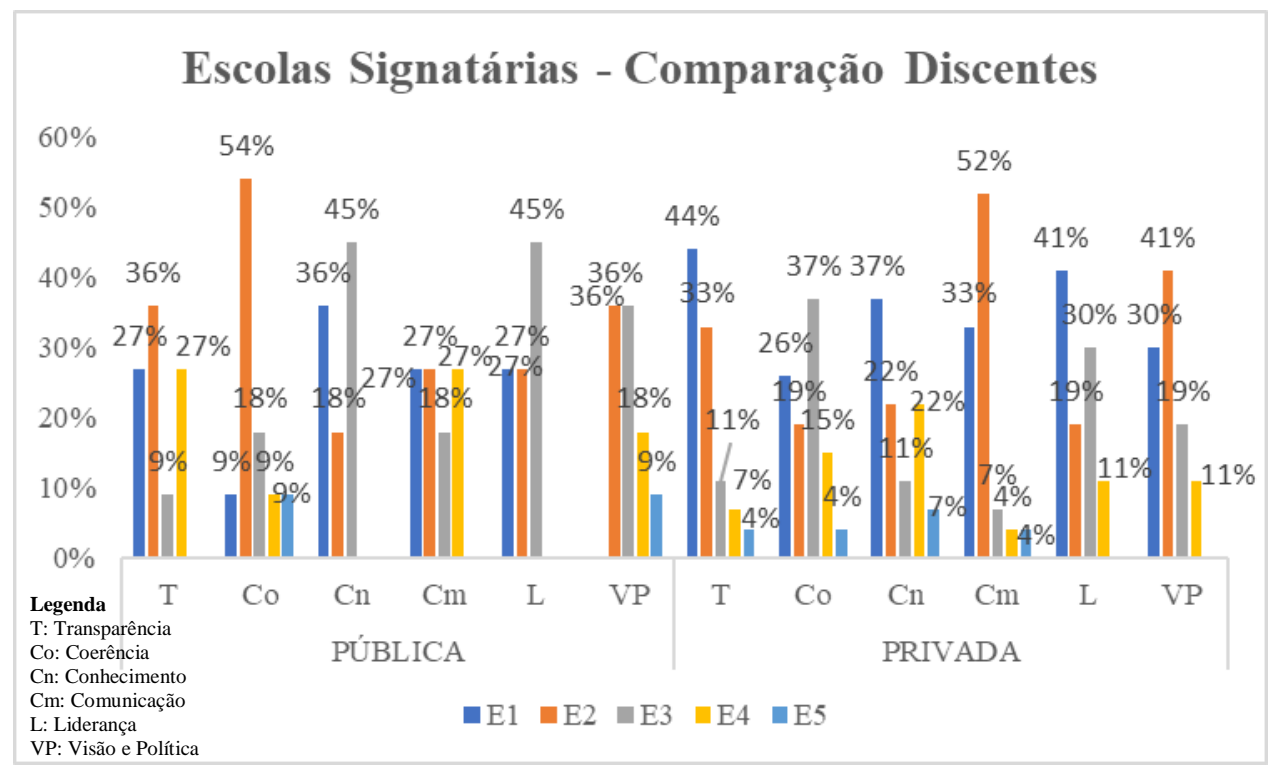

Fonte: Dados da pesquisa

O Gráfico 14 demonstra que os discentes das escolas signatárias, além de corroborarem a tendência à valorização das atividades das escolas signatárias do PRME em seu ambiente interno, também valorizam os critérios de identidade da escola no ambiente externo. Entre eles estão o conhecimento, a comunicação, a liderança e a visão e política. A despeito dos valores percentuais reduzidos em relação aos critérios e estágios que expressam a identidade da escola no seu ambiente interno, constata-se a formação em educação ambiental formal pelas práticas em grupos multidisciplinares (LEONARDI, 2002), consequentemente, com múltiplos significados associados à sustentabilidade (FREITAS, 2004), sob a expectativa de que esta formação possa contribuir para a transformação das atividades nas empresas (SCHRETTLE et al., 2014).

É interessante destacar que ao comparar esses resultados com a análise de conteúdo dos PPCs, as valorizações dos discentes das escolas signatárias do PRME sobre os critérios que atingem os estágios externos a elas, expressam a incorporação da sustentabilidade como dimensão do desenvolvimento sustentável, fortalecendo o pressuposto de que a educação se constitui em estratégia de formação de consciências (EDWARDS, 2013). Se este é um componente positivo da educação ambiental, emerge a preocupação de que os conteúdos sobre objetivos, perfil do egresso, diretrizes e metodologias de ensino e disciplinas obrigatórias e optativas apresentados nos PPCs estão desacoplados ao modelo PRME e da identidade sustentável das escolas. Portanto, é sob este quadro que emerge a alternativa de 
integrar a sustentabilidade e a responsabilidade corporativa nos cursos de administração das escolas (HIND; WILSON; LESSEN, 2009), as quais se afastam dos critérios e dos estágios que definem a identidade sustentável da escola, conforme empregado nesta investigação.

Gráfico 15 - Compração Docentes - Escolas Não Signatárias

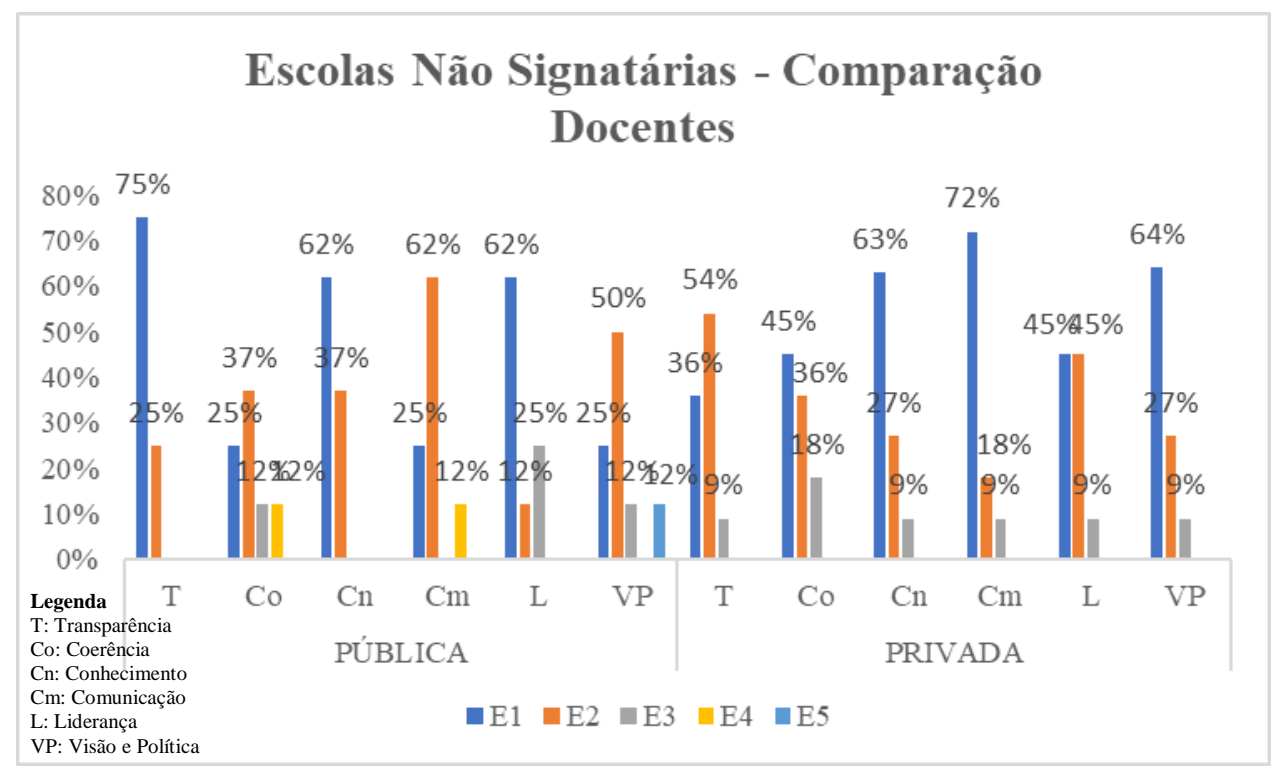

Fonte: Dados da pesquisa

A análise dos docentes das escolas públicas e privadas não signatárias do PRME revela uma discrepância em relação aos docentes das escolas signatárias. Isto é, nas escolas não signatárias, os critérios de identidade são valorizados apenas nos estágios internos a ela. A despeito da atribuição de percentuais menores à valorização dos critérios no seu ambiente externo, os docentes das escolas signatárias apresentam alguma apreensão do modelo PRME.

Pelas análises dos PPCs das escolas, especialmente sobre as diretrizes e metodologias de ensino e o oferecimento das disciplinas dos cursos, esta apreensão está distante da reflexão crítica sobre as práticas dos docentes no contexto das escolas (TARDIF, 2002). Como consequência, há a tendência em construir tipologias dos professores apenas sobre as dimensões da experiência docente e a vivência gerencial (SOUZA-SILVA; DAVEL, 2005), ou mesmo discutir questões sobre a gestão responsável, uma vez que ela se constitui no principal papel da organização (SNELSON-POWELL; GROSVOLD; MILLINGTON, 2016). Portanto, o emprego de termos comuns ao modelo PRME não significa que o modelo é apreendido pelos docentes em questão. 
Gráfico 16 - Comparação Discentes - Escolas Não Signatárias

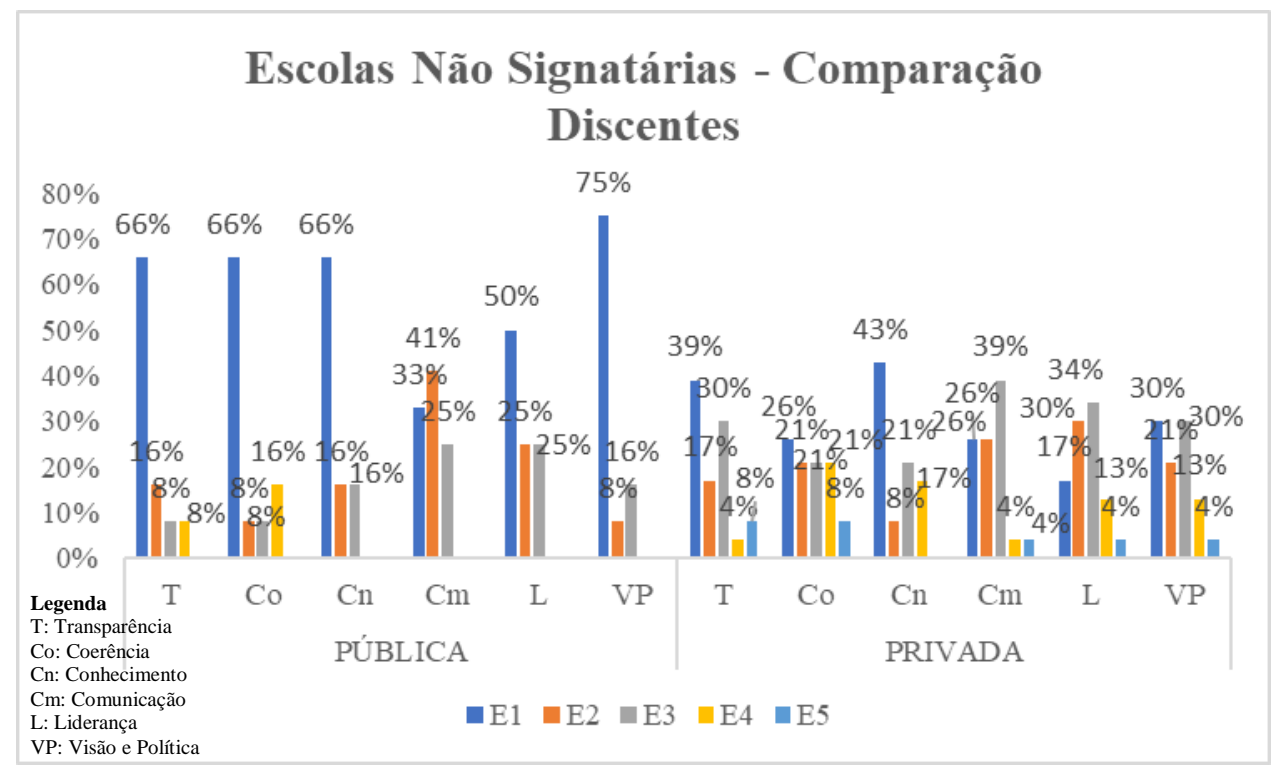

Fonte: Dados da pesquisa

Na comparação entre discentes das escolas não signatárias, o Gráfico 16 ilustra duas tendências: a dos discentes da escola pública em valorizarem intensamente os critérios pelos estágios internos a ela e a dos discentes da escola privada em diversificarem a valorização dos critérios nos estágios interno e externo à escola. $\mathrm{O}$ envolvimento externo, entretanto, seguindo as tendências dos discentes das escolas públicas e privadas signatárias, é direcionado pelas práticas ambientais vinculadas ao desenvolvimento ambiental, onde os recursos naturais se constituem em referências para as oportunidades dos negócios. Este enfoque, entretanto, é coerente com o perfil do egresso e com os objetivos dos cursos apresentados nos PPCs das quatro escolas, indistintamente.

Como consequência, emergem as preocupações quanto à formação das lideranças, especialmente designadas como responsáveis. A alternativa pode ser a empresa como instituição a desenhar modelos de liderança (LILI; XIAOXIAO, 2019). Por outro lado, há a proposição de que a escola precisa se adequar, bem como os professores, em relação a mudança educacional e a formação de líderes (HARGREAVES, 2007). O que se infere é que mudanças são necessárias e que a liderança responsável é um compromisso de todos os líderes (HARGREAVES; FINK, 2003), reforçando, sobretudo, as variáveis econômicas, sociais e psicológicas das pessoas (NORTHOUSE, 2004). 
A partir destas proposições conceituais e ao assumir o comprometimento do líder com os seus seguidores, pelo poder adquirido e influências exercidas, (MINUZZI; FILHO; SANTOS, 2009), é interessante rever o papel das instituições de ensino e, em particular, os cursos de Administração das escolas signatárias do PRME. Se, por um lado, a universidade é responsável pela construção do conhecimento (FIGUEIREDO; GUERRA; CARLETTO, 2014), por outro lado está o PRME, pelas escolas signatárias, como referência para a transformação da gestão educacional (COLEMANN et al., 2014).

Não obstante, os dados gerados sobre os discentes das quatro escolas evidenciarem o distanciamento entre estas proposições e as tendências empíricas. Neste sentido, é interessante destacar as contribuições sobre as escolas de negócios e a formação de lideranças. Elas colocam o modelo PRME em questão. Por exemplo, o que ensinar e por que ensinar os futuros líderes empresariais para enfrentarem os desafios de liderar com integridade no ambiente global é uma questão em aberto (STACHOWICZ-STANUSCH, 2011). Por outro lado, a gestão educacional responsável, como é proposto pelo PRME, não pode ser construída sobre o pressuposto de que há a gestão irresponsável (FORRAY; LEIGH, 2012).

As evidências empíricas desta investigação constatam que o PRME, como gestão educacional do futuro, requer o exercício crítico de suas proposições (LOUX, 2014). A partir das análises das quatro escolas, duas signatárias e duas não signatárias, a limitação principal está na concepção do PRME como modelo e a sua operacionalização junto às escolas. Como modelo, o PRME requer a sua formalização estrutural, o que envolve a identificação de como os seis princípios podem ser integrados entre si. Por exemplo, diálogo seria o princípio mais abrangente que nortearia a elaboração dos propósitos, dos valores, da metodologia e da parceria? Quais os tipos de diálogos devem ser introduzidos e com qual frequência? Para aplicar cada princípio, quais seriam os atores envolvidos?

Somente após estas definições, há a necessidade de rever as formas de operacionalizar cada princípio, mantendo-os integrados. O que esta investigação constata é que fases na operacionalização do modelo devem ser definidas, tais como a da apreensão, a da implementação e a da incorporação. Paralelamente a elas, é relevante a proposta de construção de indicadores (PACTO GLOBAL-RED COLOMBIA, 2018).

Para complementar esta análise comparativa, a partir da identificação dos estágios em que se encontram os critérios de identidade sustentável, há a análise comparativa dos quatro Projetos Político Pedagógicos dos Cursos. O objetivo desta análise é identificar as relações 
entre as classes de palavras e, a partir delas, estabelecer as inferências prováveis sobre os segmentos de texto das escolas. Deve-se destacar que, diferentemente da análise anterior de cada PPC em cada escola, a análise comparativa estende a compreensão sobre aqueles textos isolados, estabelecendo as aproximações e distanciamentos entre as palavras dos segmentos de texto. Esta estratégia permite a identificação de classes, entre as palavras, gerando termos e conceitos que revelam as proximidades e distanciamentos das proposições das escolas em relação àquelas que se constituem nas referências orientadoras do PRME para a mudança na gestão educacional.

Esta análise se inicia com o dendograma de classificação hierárquica, apresentado pelo Gráfico 17. Este tipo específico de diagrama, ao organizar as palavras agrega estas palavras em três classes, assumindo que em cada classe há a correlação entre as palavras, o que permite formar um esquema hierárquico de classes. Assim, a correlação associa os vocabulários semelhantes entre si e os diferencia dos vocabulários nos segmentos de texto. $\mathrm{O}$ importante é que, pela correlação entre as palavras em cada classe, é possível contextualizálas, construindo os diferentes enfoques existentes nos segmentos de texto. 
Gráfico 17 - Dendograma representativo dos segmentos de textos dos PPCs

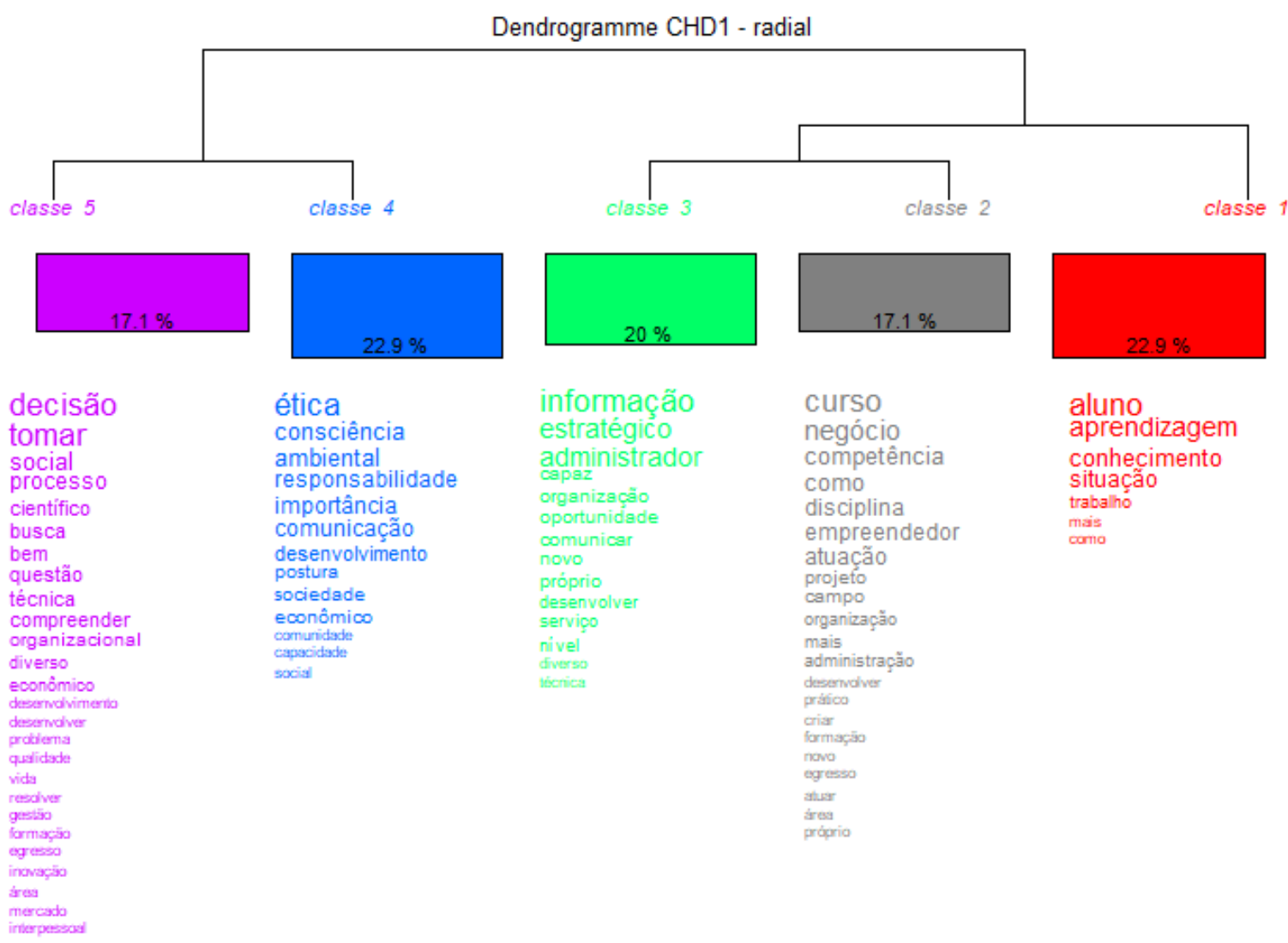

Dendrogramme CHD1 - phylogram

Fonte: Dados da pesquisa

O Gráfico 17 delineia o dendograma em duas repartições, onde a primeira é constituída de uma classe e de duas subclasses, e a segunda repartição é constituída por duas classes. As classes 1, 2 e 3 estão sob a mesma repartição porque elas apresentam mais aproximação entre si. Pelo conjunto de palavras na classe 1, pode-se definir que o seu foco é o aluno e a sua formação. De forma associada, as subclasses 2 e 3 se referem ao curso e à formação técnica.

Por sua vez, a outra repartição agrega as classes 4 e 5: a classe 4, enfatizando os valores básicos e éticos da formação, e a classe 5 focalizando o processo de decisão em inovar. Associada à identificação conceitual dos fatores que expressam os segmentos dos textos dos PPCs, o que se destaca, também, é a carga percentual em cada classe.

Como se pode identificar no Gráfico 17, as maiores cargas percentuais estão na classe 1 e na classe 4. São dois componentes de duas repartições, mas que revelam a ênfase dos PPCs sobre a formação do aluno associada aos valores básicos e éticos. Por outro lado, as 
menores cargas percentuais são das classes que focalizam a dimensão técnica do curso e a relevância do processo de decisão inerente ao curso.

Em função das classificações das palavras e da agregação sob os diferentes fatores, pode-se constatar a semelhança dos vocábulos empregados pelas escolas na elaboração dos PPCs, semelhança esta decorrente da legislação existente sobre a elaboração dos projetos políticos pedagógicos em geral. A uniformidade entre os PPCs pode ser ilustrada pelos dados relativos à análise léxica do Iramuteq, que é apresentada na Tabela 3.

Tabela 3 - Lexografia básica dos PPCs

\begin{tabular}{l|c|c|c}
\hline \multicolumn{1}{c|}{ Escolas } & No. de Ocorrências & No. de Palavras & Hapas-\% \\
\hline PRME - Pública & 665 & 366 & 76 \\
\hline PRME - Privada & 650 & 355 & 75 \\
\hline $\begin{array}{l}\text { PRME - Pública Não } \\
\text { Signatária }\end{array}$ & 514 & 296 & 77 \\
\hline $\begin{array}{l}\text { PRME - Privada Não } \\
\text { Signatária }\end{array}$ & 399 & 244 & 81 \\
\hline
\end{tabular}

Fonte: Dados da pesquisa

Como constatado pela Tabela 3, as escolas signatárias do PRME se assemelham em ocorrências sobre os números das palavras. Do mesmo modo, há semelhanças entre as escolas não signatárias quanto ao mesmo critério. Além disso, as quatro escolas se assemelham quanto à identificação de palavras que ocorrem apenas uma vez. Portanto, além da semelhança entre os termos, a própria estrutura disponibilizada pela legislação para a elaboração dos PPCs gera uniformidades entre elas. Portanto, a mudança implica na construção de uma agenda institucional construída sob diferentes fundamentos, como comunidade-aprendizes sobre sustentabilidade (GONÇALVES-DIAS; HERRERA; CRUZ, 2013).

Entretanto, as semelhanças são dissipadas quando a análise se concentra sobre os significados atribuídos a eles no PPCs e os existentes no conceito de identidade sustentável da escola e do modelo PRME. Por exemplo, ao comparar os significados dos princípios, propósitos, valores, método, pesquisa, parceria e diálogo do PRME, com as palavras constantes das classes identificadas pelo dendograma do Gráfico 13, notam-se apenas algumas semelhanças. Apenas para ilustração, os propósitos se afastam no que diz respeito à 
ênfase no curso para o desenvolvimento de capacidades sobre a economia global inclusiva e sustentável. Apenas para ilustração, os propósitos do PRME se afastam dos objetivos constantes dos PPCs das quatro escolas investigadas, pois o PRME enfatiza o desenvolvimento de capacidades sobre a economia global inclusiva e sustentável, enquanto os PPCs das escolas se restringem ao desenvolvimento de competências e habilidades técnicas. Por sua vez, os valores deixam de ser a base ética da profissão, para a da responsabilidade social global, enquanto o método visa à aprendizagem para a formação de liderança responsável, e não somente a referência às diretrizes educacionais. Sob a mesma tendência, a pesquisa, a parceria e o diálogo se estendem à participação dos educadores, estudantes, empresas, governo, consumidores, meios de comunicação, organizações da sociedade civil e outros grupos interessados. Esses três vocábulos não estão restritos aos segmentos internos da instituição, como constatado nas análises anteriores.

Em decorrência destas constatações, há, sob uma perspectiva, os PPCs como expressão da instituição como ensino, pesquisa e extensão e, por outra, as novas orientações como quadro de referência para a gestão educacional responsável. Ambos são construídos sob premissas diferentes, evidenciando uma lacuna entre eles, a qual se estabelece pelos obstáculos dos projetos pedagógicos se adequarem às novas orientações e pelos obstáculos das novas orientações se ajustarem aos projetos políticos pedagógicos. Entretanto, entre ambos está o risco de as instituições assimilarem a sugestão de que o PRME propõe apenas mudanças nos currículos dos cursos, na pesquisa e nas metodologias de aprendizagem (ALCARAZ; THIRUVATTAL, 2010).

Pelo contrário, pode-se admitir que, como formalidade instituída, os projetos políticopedagógicos podem se adequar às novas orientações, mas isto requer mais ajustes na transferência das novas orientações associadas às adequações das instituições de ensino. Sem se concentrar nestas mudanças, o que se constata é que o Fórum de Desenvolvimento das Nações Unidas introduz estratégias para a adequação dos projetos políticos pedagógicos à compreensão e implementação das orientações sobre a gestão educacional responsável. Além dos dados analisados, a revisão dos estudos sobre o tema, na revisão de literatura, tem revelado que as mudanças lentas nos projetos político pedagógicos, como a introdução de uma ou duas disciplinas, o ensino da sustentabilidade nos cursos, o suporte à pesquisa acadêmica aplicada à sustentabilidade etc., não são suficientes. 
O que se propõe é que investigações possam ser dirigidas para solucionar a questão da lacuna identificada, especialmente sobre a introdução de novos conceitos, e não somente a operacionalização de intervenções. Neste sentido, pode-se sugerir o emprego do conceito de rede de responsabilidade sustentável, onde diversos atores institucionais, acadêmicos e gestores se constituem nos componentes da rede, com definições específicas sobre as interligações entre esses elos. Portanto, as estratégias de superação da lacuna constatada nesta investigação estão dependentes de investigações que identifiquem os elos da rede e as conexões necessárias para o seu funcionamento efetivo. 


\section{CONCLUSÕES}

A investigação sobre a gestão educacional das quatro escolas de negócios gera inferências que estão além daquelas oriundas dos resultados fundamentados pelos dados. Em virtude das inferências possíveis, elas serão destacadas, em itens específicos, em função dos seus conteúdos.

\subsection{Sustentabilidade e Gestão Educacional}

Ao formular que a questão investigada é o conhecimento em sustentabilidade, tornase necessário explicitar o quadro de referência conceitual proposto e as diferenças conceituais de significados para o mesmo termo. Delimitado o PRME como referência, é fundamental compreender os significados atribuídos ao termo sustentabilidade, os quais se afastam do conceito de gestão sustentável da escola, pois, o PRME é, principalmente, um modelo de gestão educacional, com proposições complexas e abrangentes sobre as diferentes dimensões do ambiente acadêmico.

A revisão de literatura permite identificar que a tendência, nos trabalhos teóricos/conceituais e nas pesquisas pertinentes, é a de associar a sustentabilidade, nas formações de gestores das empresas e de professores das instituições de ensino, associados à dimensão ambiental e social. Portanto, acrescenta-se à dimensão econômica duas outras, que são demandadas pela sociedade.

Esta apreensão do significado de sustentabilidade tem gerado investigações sobre o docente, o discente e os segmentos dos projetos políticos pedagógicos dos cursos, como unidades de análise. Especialmente em relação a esta última unidade, ela não é investigada como um conjunto integrado de proposições do curso, mas o foco recai sobre disciplinas, principalmente, as quais são analisadas por abordarem os conteúdos ou disciplinas de sustentabilidade e ética, sustentabilidade ambiental etc.

A conclusão é de que esta abordagem é restritiva, no que diz respeito à compreensão da sua incorporação nas escolas de negócios. Assim, a partir desta constatação, o estudo em questão problematiza a incorporação da orientação do modelo PRME nas escolas de negócios, pela apreensão dos docentes e discentes formandos sobre o conceito de identidade sustentável da escola. Nota-se que há a distinção entre dois momentos no processo de disseminação do PRME, qual seja, a abordagem pela incorporação e a abordagem pela apreensão ou compreensão do PRME como modelo de gestão educacional. 
Na abordagem sobre a apreensão do PRME, o conceito de identidade sustentável da escola passa a ser a operacionalização do modelo de gestão educacional do PRME, pois o mesmo contempla os princípios da orientação sustentável da escola. Além disto, esta apreensão se estende à análise do projeto político pedagógico dos cursos, analisando a integração entre os seus componentes clássicos, quais sejam, o perfil do egresso, objetivos do curso, diretrizes de ensino e aprendizagem, e disciplinas curriculares.

\subsection{Os instrumentos de análise}

O emprego dos instrumentos de análises é formalizado a partir dos conceitos que eles expressam. Assim, a análise de conteúdo pela nuvem de palavras e a análise dos vocábulos pela Classificação Hierárquica Descendente (CHD) expressam termos que podem ou não serem contemplados na definição das proposições do modelo de gestão do PRME. Portanto, a ocorrência dos termos retrata apenas as similitudes, pois os significados são atribuídos pelo AISHE.

Este instrumento, foi validado, com o consentimento do seu autor, para poder ser empregado nesta pesquisa. O interessante deste instrumento é que conceitualmente ele se refere a avaliação da sustentabilidade nas universidades e o PRME é o modelo de gestão educacional responsável, ambos com os mesmos conteúdos, permitindo avaliar a extensão com que os termos ou vocábulos são empregados nos PPCs. Isto é, no seu ambiente interno e ou externo ou em ambos. Em outros termos, critério e estágios do instrumento AISHE possuem uma valorização conceitual em função do quadro de referência que orienta a análise, que é a incorporação do modelo PRME.

\subsection{0 delineamento empírico}

Ao investigar a compreensão do conhecimento em sustentabilidade sob o modelo PRME como quadro de referência, houve a separação das escolas signatárias, de acordo com o encaminhamento do SIP, entre escolas públicas e privadas. Este delineamento permite controlar a ocorrência da assimilação pelo fato de as escolas serem de diferentes naturezas. Não obstante, esta base empírica foi ampliada em função de outra proposição teórica, decorrente do emprego do modelo PRME como quadro de referência conceitual. Isto é, a investigação considerou duas outras escolas não signatárias do PRME, para identificar se o 
conhecimento em sustentabilidade pela identidade sustentável da escola seria devido ao fato de as escolas serem signatárias.

Deste modo, o instrumento AISHE foi encaminhado para os docentes das quatro escolas, diferentemente da aplicação deste instrumento aos discentes, uma vez que a aplicação ocorreu nas salas de aula. O interessante foi detectar a taxa de retorno das respostas dos docentes, a qual ficou acima de $30 \%$, usualmente, como "rule of thumb", considerada como muito boa. Entretanto, constatou-se que a taxa de retorno dos docentes das escolas não signatárias é maior do que as dos docentes das escolas signatárias. Este dado permite inferir que, pelo delineamento da pesquisa, os docentes das escolas signatárias não apreendem o diálogo, princípio no. 6 do PRME, como orientação para a interação com o ambiente externo, especialmente com os demais centros de pesquisas.

\subsection{A Identidade Sustentável das Escolas}

Da análise sobre os dados referentes aos docentes da escola pública signatária, identifica-se que o módulo identidade, pela análise dos seis critérios e dos respectivos estágios, caracteriza a ocorrência da gestão educacional responsável da escola no nível local. Esta inferência é fundamentada pelos valores percentuais das respostas nos estágios 1 e 2, alcançando, em alguns dos critérios, o estágio 3. Entretanto, deve-se destacar que este estágio fortalece as atividades da escola como sistema. Portanto, ao assumir que os critérios do módulo se constituem em orientações do PRME, pode-se admitir que a gestão responsável pela transformação da gestão educacional é, na percepção dos docentes da escola PRME Pública, apenas parcial.

Na visão dos discentes desta escola, o que se infere dos seis critérios que expressam as atividades da escola sobre a sua identidade é a constatação dos critérios de coerência, e visão e política, como expressões da identidade da gestão responsável para o ambiente externo. Os demais critérios fortalecem a visão interna da identidade da escola. Deste modo, constata-se a relevância do desenvolvimento da identidade sustentável nos ambientes interno e externo da escola. Portanto, pode-se admitir que os discentes do curso de administração, da escola Pública, signatária do PRME, têm a percepção sobre a identidade sustentável da escola mais desenvolvida, em comparação com a percepção dos docentes da mesma escola.

$\mathrm{Na}$ análise dos conteúdos dos textos do PPC da escola PRME-Pública, identificou-se a ocorrência de termos similares aos do modelo PRME e o instrumento AISHE, tal como o 
termo conhecimento. Enquanto conhecimento expressa a natureza do conteúdo técnico do curso, as respostas dos docentes e discentes desta escola demonstram que o conhecimento depende das iniciativas individuais, que se estruturam por um plano elaborado pela equipe, estando disponibilizado às partes interessadas, ou seja, estruturam-se pelo ambiente interno da escola.

Além disto, a matriz curricular, ao longo de 10 anos, incluiu apenas duas disciplinas com os conteúdos que abordam a sustentabilidade. Uma é ofertada no $2^{\circ}$ período do curso, e a outra no $5^{\circ}$ período. Se esta inserção representa a introdução das demandas da sociedade, ela, ao mesmo tempo, expressa a natureza lenta da mudança que ocorre em relação à elaboração do PPC do curso. Deve-se destacar que, ao ser signatária do PRME, a instituição se submete a várias exigências explícitas no modelo de gestão educacional e não apenas a algumas delas, como métodos de aprendizagem, ajuste de currículo, etc.

Quanto à escola privada, signatária do PRME, as tendências são as mesmas. Em relação aos docentes, as atividades relacionadas à identidade sustentável da escola se concentram nos estágios que caracterizam o ambiente interno da escola. Do mesmo modo como os docentes da escola pública signatária, os da escola PRME-Privada atribuem valores percentuais relativamente baixos aos estágios que caracterizam o ambiente externo. Em ambas as situações, isto evidencia que há interações com o ambiente externo, mas que não se expressa de forma relevante como o ambiente interno.

Em relação aos discentes da escola privada, signatária do PRME, constata-se que eles, além de destacarem a relevância dos critérios nos estágios internos à escola, expressam também a valorização dos estágios que evidenciam o envolvimento da escola com o ambiente externo. Há o destaque sobre a importância do feedback da sociedade, para a escola, a identificação da sinergia com os atores, onde o centro de excelência contribui para a sociedade, expresso por um processo de comunicação ativo. Portanto, pode-se inferir que os discentes possuem a percepção mais abrangente do que a dos docentes, sobre a identidade sustentável da escola.

A análise dos conteúdos do PPC desta escola privada signatária apresenta conteúdos distintos daqueles das demais escolas em análise, expressando proposições inerentes tanto no modelo PRME quanto nos critérios de identidade sustentável da escola. Aos egressos, destaca a formação de lideranças e de negociador, além da formação ética, onde a responsabilidade social é definida como sendo a responsabilidade em relação às dimensões econômicas, socias 
e ambientais. O objetivo enfatiza o desenvolvimento de competências sociais, organizacionais e técnica, contemplados com disciplinas articuladas, abordando temas transversais e abordagens interdisciplinares, com o estímulo para a pesquisa, a organização e a participação em eventos e estágios vivenciais em empresas.

Não obstante, as disciplinas regulares do curso revelam a formação sob a dimensão técnica do curso. Assim, infere-se que a formação como liderança, ambiente e bem-estar social depende das práticas e de atividades não regularmente requeridas. Em outros termos, a abordagem conceitual do PPC desta escola PRME Privada é uma, e a sua prática na formação dos discentes é outra.

Esta conclusão é fortemente corroborada pelas respostas dos docentes da escola PRME Privada aos critérios de identidade sustentável da escola, e constatada pelas repostas dos discentes aos mesmos critérios. A diferença entre docentes e discentes é que algumas atividades, talvez as que permitem iniciativas dos estudantes, podem estar alcançando o ambiente externo da instituição e a formação parcial em relação às proposições do modelo PRME e aos critérios de sustentabilidade da escola.

Esta tendência também é corroborada pela análise dos vocábulos dos textos do PPC. Neste documento, a escola emprega termos que são comuns ao modelo PRME e ao instrumento AISHE sobre a orientação para a formação de uma gestão responsável pela escola. Não obstante, ao identificar que a oferta das disciplinas não direciona a este desenvolvimento, constata-se a tendência da instituição em apresentar as diretrizes gerais, apenas, deixando disciplinas e atividades opcionais para a complementação da formação dos discentes.

Para os docentes da escola pública não signatária, os seis critérios do módulo identidade expressam a visão de gestão responsável local, essencialmente determinada pela realização das atividades nos estágios 1 e 2. Entretanto, sobressaem-se a transparência e a visão política como critérios que alcançam o ambiente externo da instituição. Por outro lado, a comunicação e a liderança, aspectos essenciais na constituição da gestão responsável, são pouco desenvolvidos nos diferentes estágios. Estas tendências, como constatadas nos resultados encontrados até então, revelam apenas que há a interação com o ambiente externo, mas insuficiente para expor a escola a ele.

No geral, também se pode inferir que para os discentes desta escola, não signatária do PRME, os seis critérios de identidade sustentável da escola mostram a relevância do ambiente 
interno, na sua imagem. Não obstante, a percepção dos discentes sobre a identidade sustentável da escola é mais desenvolvida do que a percepção dos docentes. Entretanto, ela não se aproxima do que consta das proposições do PRME, como quadro de referência para a mudança dos papeis das escolas de negócio.

O que se destaca, até então, é que esta constatação não ocorre apenas em relação a esta escola não signatária do PRME. Pelo contrário, ela também se verifica entre as escolas pública e privada, signatárias do PRME, o que é, também, corroborado na análise dos conteúdos do PPC desta escola. Ele possui termos que são similares aos do modelo PRIME, mas com significados diferentes, quando se analisa os estágios em que os critérios de identidade ocorrem. Assim, a inferência possível, sobre esses dados, é que o desacoplamento entre o PCC e os critérios do AISHE e o PRME se constituem na principal lacuna a ser transposta, para que a escola seja inserida nos propósitos da nova educação responsável, nas escolas de negócios.

Em relação aos docentes da escola privada não signatária, tem-se, também, a configuração do módulo identidade fundamentada pelos seis critérios, mas estes desenvolvidos, especificamente, no seu ambiente interno. Assim, a visão sobre a identidade sustentável da escola é pouco desenvolvida, apesar da constatação da ocorrência de poucos percentuais de respostas no estágio intermediário. Estes dados contrastam com a relevância atribuída pelos discentes desta mesma escola aos estágios 4 e 5, revelando a realização das atividades associadas à identidade da escola em relação ao ambiente externo. Portanto, na percepção destes discentes, a identidade sustentável é mais desenvolvida, o que permite inferir que, apesar de não ser signatária, esta escola incorpora orientações gerais do modelo PRME e dos critérios de identidade que expressam a gestão institucional responsável.

Na análise de conteúdo dos segmentos dos textos do PPC desta escola, identificou-se a ênfase na orientação técnica e científica, onde a frequência de ocorrência dos vocábulos evidencia a ênfase na formação técnica e científica da área da Administração. Entre os termos, destaca-se a ocorrência da palavra prática, que ilustra a possibilidade de ações dos estudantes com os atores da sociedade.

Ao comparar docentes e discentes das escolas pública e privada, signatárias do PRME, nota-se a mesma tendência, na avaliação dos estágios e dos critérios de identidade sustentável da escola. Há a apreensão de que a identidade se concentra no seu ambiente interno, ambiente este caracterizado por atividades integradas a um processo que envolve a equipe de pesquisa, 
estudantes e funcionários. Portanto, o fato de as escolas signatárias se diferenciarem em pública e privada não implica em menor ou maior comprometimento com as orientações do modelo PRME e nem com os critérios de identidade sustentável. Pelo contrário, nem uma, nem outra incorpora aquelas orientações sobre a gestão sustentável da instituição.

Esta constatação também se estende aos docentes e discentes das escolas não signatárias, pública e privada. Há apenas a referência dos discentes destas escolas, que estendem as atividades ao ambiente externo, diferentemente da apreensão dos docentes. Além disto, constatam-se as interações dos discentes da escola privada com o ambiente externo. Esses dados permitem inferir sobre o maior envolvimento dos estudantes com as demandas da sociedade, uma vez que suas atividades se afastam das preconizadas no modelo PRME e dos critérios de identidade. Portanto, eles se apropriam das orientações implícitas no Projeto Pedagógico Político dos Cursos.

O que se infere desta conclusão é que, pelos PPCs, as mudanças introduzidas são lentas e se afastam do modelo PRME, pois consistem em revisão dos procedimentos pedagógicos, dos currículos, a criação de disciplinas sobre o tema sustentabilidade, etc. São iniciativas isoladas e não são suficientes para envolver a escola com a gestão educacional responsável, conforme a interpretação sobre a revisão da literatura realizada e a identidade dos termos quando se elas se referem ao modelo de gestão educacional do PRME

$\mathrm{O}$ aspecto principal é que esses projetos, independentemente de as escolas serem públicas ou privadas, signatárias ou não signatárias, seguem as orientações da legislação para a sua elaboração. Essas orientações implicam no emprego de palavras comuns ao modelo PRME e aos critérios de identidade, não sendo, porém, introduzidas sob os mesmos propósitos.

Portanto, o desacoplamento das escolas, especialmente as signatárias, é devido a dois fatores, quais sejam, a estrutura legal que orienta a elaboração e implementação do PPC, e a o fato de as escolas serem voluntárias neste processo. Especialmente em relação a esse último aspecto, as escolas se comprometem com as inovações do quadro instituído internacionalmente, que é o PRME, mas o voluntarismo as coloca em uma situação de dependência apenas das potencialidades de suas estrutura e organização. Para melhor compreensão destas proposições, o Quadro 16 apresenta a síntese das conclusões sobre as quais esses argumentos foram elaborados. 
Quadro 16 - Síntese das conclusões por escolas, docentes e discentes

\begin{tabular}{|c|c|c|c|}
\hline \multirow[t]{2}{*}{ Escolas } & \multirow{2}{*}{$\begin{array}{c}\text { Projeto Político } \\
\text { Pedagógico do Curso }\end{array}$} & \multicolumn{2}{|c|}{ Identidade Sustentável da Escola } \\
\hline & & Docentes & $\begin{array}{c}\text { Discentes } \\
\end{array}$ \\
\hline PRME - Pública & $\begin{array}{l}\text { Adequação parcial } \\
\text { pelos termos, não pelos } \\
\text { significados. Iniciativas } \\
\text { isoladas. Mudança } \\
\text { lenta. }\end{array}$ & $\begin{array}{l}\text { Apreensão da Identidade } \\
\text { Sustentável da Escola no } \\
\text { nível local }\end{array}$ & $\begin{array}{l}\text { Apreensão da Identidade } \\
\text { Sustentável da Escola mais } \\
\text { desenvolvida. }\end{array}$ \\
\hline PRME - Privada & $\begin{array}{l}\text { Adequação maior dos } \\
\text { termos e significados. } \\
\text { Concepção se afasta da } \\
\text { prática. Mudança é } \\
\text { possível. }\end{array}$ & $\begin{array}{l}\text { Apreensão da Identidade } \\
\text { Sustentável da Escola no } \\
\text { nível local }\end{array}$ & $\begin{array}{l}\text { Apreensão da Identidade } \\
\text { Sustentável da Escola mais } \\
\text { desenvolvida. }\end{array}$ \\
\hline Não PRME - Pública & $\begin{array}{l}\text { Termos similares, } \\
\text { significados diferentes. } \\
\text { Não há sinal de } \\
\text { mudança. }\end{array}$ & $\begin{array}{l}\text { Apreensão da Identidade } \\
\text { Sustentável da Escola no } \\
\text { nível local }\end{array}$ & $\begin{array}{l}\text { Apreensão da Identidade } \\
\text { Sustentável da Escola mais } \\
\text { desenvolvida. }\end{array}$ \\
\hline Não PRME - Privada & $\begin{array}{l}\text { Poucos termos } \\
\text { similares. Não há sinal } \\
\text { de mudança. }\end{array}$ & $\begin{array}{l}\text { Apreensão da Identidade } \\
\text { Sustentável da Escola } \\
\text { mais restrita no nível } \\
\text { local }^{11} \text {. }\end{array}$ & $\begin{array}{l}\text { Apreensão da Identidade } \\
\text { Sustentável da Escola mais } \\
\text { desenvolvida em relação a } \\
\text { todos. }\end{array}$ \\
\hline Conclusão Geral & $\begin{array}{l}\text { Desacoplamento dos } \\
\text { PPCs em relação aos } \\
\text { Princípios e Critérios } \\
\text { de Identidade } \\
\text { Sustentável. }\end{array}$ & $\begin{array}{l}\text { Apreensão parcial dos } \\
\text { Princípios e da Identidade } \\
\text { Sustentável da escola. }\end{array}$ & $\begin{array}{l}\text { Apreensão parcial dos } \\
\text { Princípios e da Identidade } \\
\text { Sustentável da escola, porém } \\
\text { com práticas desacopladas. }\end{array}$ \\
\hline
\end{tabular}

Fonte: Elaborado pela autora

A relevância do Quadro 16 está em demonstrar que as tendências entre as escolas, signatárias e não signatárias, e entre docentes e discentes, são as mesmas. Pode-se então inferir que a forma como os princípios do PRME estão sendo introduzidos pelas escolas de negócios não alcança as mudanças na gestão educacional como preconizado pela Plataforma PRME. Em outros termos, se não existisse o modelo de gestão educacional PRME, os resultados encontrados nas escolas signatárias seriam os mesmos. Se este argumento é provável, outra inferência possível é que as escolas visam assimilar, de forma lenta, as demandas da sociedade sobre a preservação e conservação dos recursos naturais. Isto é, as escolas apreendem mais as proposições da educação para o desenvolvimento social, com a realização de práticas ambientais desacopladas da plataforma PRME, orientando-se, também, pelas oportunidades dos negócios.

Sob este cenário de inferências, a revisão sobre as formas de apresentação, introdução e disponibilização do modelo de gestão educacional PRME torna-se necessária. Portanto, em

\footnotetext{
${ }^{11}$ A apreensão da Identidade Sustentável na Escola é considerada restrita no nível local, pois os critérios se concentram nos estágios 1 e 2, e a apreensão da Identidade Sustentável no nível local a concentração é maior nos estágios 2 e 3.
} 
função deste cenário que são apresentadas, no item seguinte, as contribuições e limitações dessa pesquisa.

\subsection{Contribuições e Limitações da Pesquisa}

A sugestão inicial decorre da investigação sobre a apreensão do modelo de gestão PRME nas escolas pública e privada signatárias. Para a apreensão, etapa necessária para a incorporação do modelo e a sua adoção institucional, torna-se necessário definir mecanismos de intervenções efetivos, pois sem o conhecimento do PRME como modelo de gestão educacional, a probabilidade de sua incorporação é reduzida, delimitada pela disposição voluntária da instituição. Esta sugestão está em consonância com as propostas sobre a análise crítica em relação ao PRME (LOUX, 2014; CABRERA, 2014), ao mesmo tempo que complementa as abordagens sobre a incorporação do PRME (HIND; WILSON; LENSSEN, 2009; GARCIA, 2013).

Um fato que revela a incompreensão sobre a proposta do PRME está na sua tradução. Usualmente, ele é traduzido como educação executiva responsável, mas que possui fundamentos e estratégias diferentes da gestão educacional responsável, como consta no PRME. Como retratado na revisão de literatura, a educação executiva se estrutura por intervenções oriundas dos modelos de desenvolvimento sustentável, da formação de professores e da formação de lideranças, onde as dimensões sociais e ambientais da sociedade são acrescidas à dimensão econômica dos negócios. Com a revisão e a operacionalização dos conceitos e a integração dos princípios, em uma estrutura integrada de proposições, pode-se superar a questão sobre o que ensinar e o por que ensinar (STACHOWICZ-STANUSCH, 2011), além de explicitar os fundamentos da gestão educacional responsável (FORRAY; LEIGH, 2012).

Além disto, a consequência da ausência de mecanismos ou estratégias de implementação do PRME por parte da ONU possui outra implicação, qual seja, a proposta de construção de indicadores que evidenciam a natureza e a intensidade do envolvimento de instituições voluntárias ao PRME (PACTO GLOBAL-RED COLOMBIA, 2018). Complementando essa abordagem, o objetivo dos indicadores é também de identificar se a instituição está em processo de mudança, e qual a sua intensidade. Não obstante, sob a perspectiva da avaliação, a construção de indicadores decorre da natureza da mudança 
projetada e das ações associadas para que a mudança ocorra. Não existem indicadores sem a estrutura conceitual de implementação e o monitoramento das intervenções.

Portanto, há necessidade de duas intervenções do Fórum de Desenvolvimento das Nações Unidas para a incorporação do PRME nas instituições signatárias: a) a introdução de estratégias para a adequação dos projetos políticos pedagógicos à apreensão e implementação das orientações sobre a gestão educacional responsável, e não somente a identificação de disciplinas existentes ou criadas sob os propósitos de sustentabilidade e responsabilidade corporativa (HIND; WILSON; LENSSEN, 2009; GONÇALVES-DIAS; HERRERA; CRUZ,2013; VIEIRA, 2014), e b) definir e introduzir estratégias que induzam à incorporação do PRME nas instituições, superando as questões do voluntarismo institucional, complementado a tese sobre o desacoplamento (RASCHE; GILBERT, 2015; SNELSONPOWELL; GROSVOLD; MILLINGTON, 2016).

Neste sentido, há a sugestão da criação da rede de identidade sustentável, com as definições dos seus pontos estratégicos, das interrelações entre eles, e não simplesmente articulações, e da definição das responsabilidades do gestor dessa rede. Esta sugestão pode alcançar o estágio das instituições de se transforarem em comunidades-aprendizes GONÇALVES-DIAS; HERRERA; CRUZ,2013; VIEIRA, 2014).

Portanto, a sugestão para novas investigações é a de explorar e descrever a estrutura da rede de gestão educacional sustentável, a sua organização e níveis de atuação. Por princípio, a investigação sobre construção de redes é complexa, mas alguns aspectos podem ser destacados, como a vinculação institucional da rede, identificação dos atores, definição das responsabilidades, objetivos sobre a incorporação do PRME pelas instituições signatárias, orçamento, e as implicações na superação do voluntarismo das instituições comprometidas com o PRME.

Além disto, há a necessidade de rever o delineamento empírico. Tanto quanto possível, desenvolver a coleta e análise dos dados antes e após o fato das escolas serem signatárias do PRME. Esta não delimitação temporal passa se constituir em uma das vulnerabilidades desta investigação. A outra estaria na não seleção das demais escolas e instituições que são signatárias do PRME, e não somente escolas com os cursos de administração. Neste sentido, a abordagem comparativa passa a ser a estratégia que pode possibilitar a melhor apreensão e incorporação do modelo de gestão do PRME, nas escolas de 
negócios e instituições, complementando as análises fundamentadas no SIP, relatório que é encaminhado pelas instituições signatárias (GODEMANN et al.,2014). 


\section{REFERÊNCIAS}

ALCARAZ, J. M.; THIRUVATTAL, E. An Interview With Manuel Escudero The United Nations' Principles for Responsible Management Education: A Global Call for Sustainability. Academy of Management Learning \& Education. v. 9, n. 3, p. 542-550, 2010.

ANASTASIOU, L. das G.C. Ensinar, aprender e apreender processos de ensinagem. In ANASTASIOU, L. das G.C.; ALVES, L.P. (orgs.). Processos de ensinagem na universidade. Joinville: Univille, 2003.

CABRERA, A. Research and the Principles for Responsible Management Education. Disponível em <unprme.org/.../prmeprinciple4researchreportfi>. Acesso em 25/11/2014.

CAMARGO, B. V.; JUSTO, A. M. Tutorial para uso do software de análise textual IRAMUTEQ. Laboratório de Psicologia Social da Comunicação e Cognição. Universidade Federal de Santa Catarina., 2013.

CEZARINO, L.; LIBONI, L.; OLIVEIRA, M.; CALDANA, A. C. F. Soft Systems Methodology and Interdisciplinarity in Management Education. Systems Research and Behavioral Science, 33, 278-288. 2016.

CHATTERJRR, D. Liderança Consciente: Peregrinação rumo à conquista de si mesmo. São Paulo: Cultrix, 1998.

DIAS, B.G.; MUNCK, L.; BANSI, A. C.; CELLA-DE-OLIVEIRA, F. A. Bases Compreensivas da Sustentabilidade Organizacional: a Proposição de uma Estrutura Conceitual (Framework). In XIV Seminários em Administração. XIV SEMEAD, São Paulo, 2011.

DYLLICK, T., HOCKERTS, K. Beyond the business case for corporate sustainability. Business Strategy and the Environment. v. 11, p. 130-141, 2002.

EDWARDS, B. O guia básico para a sustentabilidade. Barcelona: Editora Gustavo Gili, 2013.

ELKINGTON, J. Cannibals with forks: the triple bottom line of $21^{\text {st }}$ century business. New Society Publishers: Oxford, 1997.

FARIAS, C. R. O. Análise dos processos de ambientalização da formação acadêmica na Universidade Federal Rural de Pernambuco. In RUSCHEINSKY, Aloisio et al. (Orgs.) Ambientalização nas instituições de educação superior no Brasil: caminhos trilhados, desafios e possibilidades. São Carlos: EESC/USP, 2014.

FIGUEIREDO, M. L.; GUERRA, A. F. S.; CARLETTO, D. L. Posfácio. Ambientalização nas Instituições de Educação Superior: Reflexões do IV Seminário Sustentabilidade na Universidade. In RUSCHEINSKY, Aloisio et al. (Orgs.) Ambientalização nas instituições 
de educação superior no Brasil: caminhos trilhados, desafios e possibilidades. São Carlos: EESC/USP, 2014.

FORRAY, J. M., LEIGH, J. S. A Primer on the Principles of Responsible Management Education Intellectual Roots and Waves of Change. Journal of Management Education. v.36, n. 3, p. 295-309, 2012.

FREITAS, M. A educação para o desenvolvimento sustentável e a formação de educadores/professores. Revista Perspectiva. v. 22, n. 2, p. 547-575, 2004.

GARCIA, R. M. C. Política de educação especial na perspectiva inclusiva e a formação docente no Brasil. Revista Educação. v. 18, n. 52, 2013.

GODEMANN, J., HAERTLE, J., HERZIG, C. \& MOON, J. United Nations supported Principles for Responsible Management Education: purpose, progress and prospects. Journal of Cleaner Production. v. 62, p. 16-23, 2014.

GONÇALVES-DIAS, S. L. F.; HERRERA, C. B.; CRUZ, M. T. de Souza. Desafios e Dilemas para inserir "sustentabilidade" nos currículos de administração: um estudo de caso. Revista de Administração Mackenzie. v. 14, n. 3, p. 119-153, 2013.

HAERTLE, J., PARKES, C., MURRAY, A., HAYES, R. PRME: building a global movement on responsible management education. The International Journal of Management Education, n. 15, p. 66-72, 2017.

HARGREAVES, A. Sustainable Leadership and Development in Education: creating the future, conserving the past. European Journal of Education. v. 42, n. 2, 2007.

HARGREAVES, A., FINK, D. The Seven Principles of Sustainable Leadership. Educational Leadership, 2003.

HIND, P., WILSON, A., LENSSEN, G. Developing leaders for sustainable business. Corporate Governance. v. 9, n. 1, p. 7-20, 2009.

JABAREEN, Y. Building a Conceptual Framework: Philosophy, Definitions, and Procedure. International Journal for Qualitative Research. University of Alberta. December 1, 2009.

JABBOUR, C.J.C. Gestão ambiental em escolas de negócios: mapeando o estado da arte. Revista Pensamento Contemporâneo em Administração. v. 8, n. 4, p. 1-2, 2014.

LEFF, E. Saber Ambiental. Petrópolis: Editora Vozes, 2002.

LEONARDI, M. L. A. A educação ambiental como um dos instrumentos de superação da insustentabilidade da sociedade atual. In Meio Ambiental, desenvolvimento sustentável e políticas públicas. São Paulo: Cortez, 2002.

LILI, Y., MO, Y., XIAOXIAO, Q. A Study on The Model of Design Leadership Strategy. IEEE, 2009. 
LOUX, J. "Paradigm Change" or No Real Change At All? A Critical Reading of the U.N. Principles for Responsible Management Education. Journal of Management Education, 2014.

MAAK, T., PLESS, N. M. Responsible Leadership in a Stakeholder Society - a relational perspective. Journal of Business Ethics, p. 99-115, 2006.

MARCONI M. A., LAKATOS, E. M. Metodologia Científica. São Paulo: Atlas, 2017.

MASETTO, M.T. Competência pedagógica do professor universitário. São Paulo: Sumus Editorial, 2012.

MINUZZI, J. FILHO, N. C., SANTOS, P. C. F. Relações entre os valores e a liderança sustentável e APLs. Revista TECAP. v.3, n.3, p. 17-23, 2009.

MUNCK, L. Em busca da sustentabilidade organizacional: a proposição de um framework. Revista Alcance. v. 20, n. 4, p. 460-477, 2012.

NOGUEIRA, C. A. Proposta de instrumento para medição do estado atual da gestão por processos nas organizações brasileiras. 2012. 134 f. Dissertação (Mestrado em Administração de Organizações) - Faculdade de Economia, Administração e Contabilidade de Ribeirão Preto, Universidade de São Paulo, Ribeirão Preto, 2012.

NORTHOUSE, P. G. Leadership: theory and practice. Thousand Oaks, CA. Sage Publication, 2004.

ONU BRASIL. Agenda 2030. Disponível em <https://nacoesunidas.org/pos2015/agenda2030/>. Acesso em: 03 de março de 2017.

PACTO GLOBAL. Pacto Global Rede Brasil. Disponível em <http://www.pactoglobal.org.br/>. Acesso em: 15 de maio de 2015.

PACTO GLOBAL-RED COLOMBIA. Sistema de Indicadores de Responsabilidade Social Universitária. Relatório de Progresso - PRME. Bogotá D.C. Colômbia, 2018.

PEREIRA, J. As licenciaturas e as novas políticas educacionais para a formação docente. Revista Educação \& Sociedade. n. 68, p. 109-125, 1999.

PRME. Anti-Corruption ToolKit. A teaching resource. Disponível em: <http://actoolkit.unprme.org/learning-methods/\#08>. Acesso em: 25 de novembro de 2014.

PRME. Strategic Review 2016. Disponível em: <http://www.unprme.org/resources/displayresources.php?cid=9>. Acesso em: 03 de março de 2017.

RASCHE, A., GILBERT, D. U. Decoupling Responsible Management Education: Why Business Schools May Not Walk Their Talk. Journal of Management Inquiry. v. 24, p. 239-252, 2015. 
RICHARDSON, R. J. Pesquisa Social: Métodos e Técnicas. São Paulo: Atlas, 2017.

ROORDA, N., RAMMEL, C., WAARA, S., PALEO, U. Assessment Instrument for Sustainability in Higher Education, 2009.

SÁENZ, O. Panorama de la sustentabilidade en las Universidades de América Latina y el Caribe. In RUSCHEINSKY, Aloisio et al. (Orgs.) Ambientalização nas instituições de educação superior no Brasil: caminhos trilhados, desafios e possibilidades. São Carlos: EESC/USP, 2014.

SCHRETTLE, S., HINZ, A., SCHERRER-RATHJE, M. Turning sustainability into action: Explaining firms' sustainability efforts and their impact on firm performance. International Journal of Production Economics. v. 147, p. 73-84, 2014.

SNELSON-POWELL, A; GROSVOLD, J.; MILLINGTON, A. Business School Legitimacy and the Challenge of Sustainability: A Fuzzy Set Analysis of Institutional Decoupling. Academy of Management Learning \& Education. v. 15, n.4, 2016.

SOUZA-SILVA, J. C., DAVEL, E. Concepções, práticas e desafios na formação do professor: examinando o caso do ensino superior de administração no Brasil. Revista Organização e Sociedade. Salvador, v. 12, n. 35, p. 113-134, 2005.

STACHOWICZ-STANUSCH, A. The implementation of Principles for Responsible Management Education in practice - research results. Journal of Intercultural Management. v. 3, n. 2, p. 241-257, 2011.

TARDIF, M. Saberes docentes e formação profissional. Petrópolis: Ed.Vozes, 2002.

VIEIRA, A. R. A formação de professores para o ensino de administração baseado em competências: possibilidades e desafios. Tese de Doutorado, apresentada à Faculdade de Economia, Administração e Contabilidade de Ribeirão Preto/USP. Ribeirão Preto, 2014. 


\section{ANEXO A - AISHE 2.0 - Versão D}

\section{MÓDULO IDENTIDADE}

Visão e Política

A universidade tem uma visão sobre sustentabilidade e responsabilidade social corporativa em geral, sobre os aspectos dentro do próprio campo de especialização e sobre as consequências disso para a política da universidade. A visão é expressa na política. Esta política traduz a visão em planos de ações concretas.

( ) Estágio 1 Orientado pela atividade. A gestão tem uma visão sobre sustentabilidade e responsabilidade social corporativa relacionada com as atividades da universidade. A política no que diz respeito a sustentabilidade é desenvolvida principalmente de cima para baixo pela gestão. Esta visão e política são formuladas implicitamente.

( ) Estágio 2 Orientado pelo processo. Os principais elementos da visão são os valores básicos e éticos da universidade. O pessoal é ativamente envolvido no desenvolvimento contínuo e na melhoria da visão e política de sustentabilidade. A visão e a política de sustentabilidade têm sido formuladas em documentos. A gestão para trabalhar a visão e a política como ações concretas, concentra-se em curto prazo.

( ) Estágio Orientado pelo sistema. A visão da universidade como um jogador chave para a sustentabilidade, pelo menos está no nível de adaptações e melhorias. Os estudantes estão ativamente envolvidos no desenvolvimento e melhoria contínua da visão e política sobre sustentabilidade. A universidade pode ser caracterizada como uma universidade de aprendizagem. A visão tem sido expressa na missão e tem sido trabalhada na política contendo objetivos que são avaliados e ajustados regularmente. A política de sustentabilidade é principalmente focada em longo prazo.

( ) Estágio 4 Orientado pela cadeia. A universidade é reconhecida pelos stakeholders como um jogador chave para a sustentabilidade, agindo em cooperação intensiva com os stakeholders no nível de longo prazo. Esta cooperação é a base para a melhoria contínua da visão e política sobre sustentabilidade, tanto para a universidade como para os stakeholders.

( ) Estágio 5 Orientado pela sociedade. Dentro da sociedade em geral, a universidade é reconhecida como um líder chave para a sustentabilidade, agindo proativamente sobre o nível de mudança sistêmica. A sociedade está ativamente envolvida na melhoria contínua e no desenvolvimento da visão e política sobre sustentabilidade. A visão é integrada com o desenvolvimento a longo prazo da sociedade e o papel da universidade.

\section{Liderança}

A gestão da universidade não é apenas formalmente responsável pela integração da sustentabilidade nas suas atividades. A universidade também assume a liderança mostrando envolvimento pessoal, que inspira a equipe, os alunos e, possivelmente, outras partes interessadas. Escuta ativamente os envolvidos, conhece e utiliza as suas ideias e opiniões, e pede feedback sobre o seu funcionamento. Assim, a universidade usa a sua autoridade de uma maneira verdadeiramente participativa.

( ) Estágio 1 Orientado pela atividade. Ocasionalmente, a gestão da universidade presta atenção e aprecia atividades relativas a sustentabilidade pela equipe e membros. 
( ) Estágio 2 Orientado pelo processo. A gestão da universidade promove a relevância da sustentabilidade ativamente e regularmente. A gestão escuta ativamente as opiniões dos membros da equipe e os estudantes, apoia iniciativas dos funcionários e estudantes.

( ) Estágio 3 Orientado pelo sistema. A gestão estimula sistematicamente, motiva e apoia os processos de integração da sustentabilidade e os funcionários que realizam esses projetos. A gestão incentiva sistematicamente a participação ativa e uma responsabilidade compartilhada entre os funcionários e os alunos no desenvolvimento e na melhoria da visão, estratégias, políticas, atividades e avaliação dos resultados. Este incentivo é baseado explicitamente em uma estratégia de médio longo prazo.

( ) Estágio 4 Orientado pela cadeia. Com base em um compromisso visível a gestão, o pessoal e os alunos juntos apoiam e ampliam as relações com os stakeholders diretos e com os centros de especialização, com o objetivo explícito de reforçar o processo de integração da sustentabilidade na universidade. Estes esforços têm lugar com base em uma visão de longo prazo.

( ) Estágio 5 Orientado pela sociedade. A gestão, a equipe e os alunos juntos estimulam e realizam um papel proativo e excelente na sociedade e no campo educacional e profissional. Desta forma, toda a universidade mostra liderança em relação à sociedade em matéria de sustentabilidade.

\section{Comunicação}

A comunicação sobre a sustentabilidade em relação a universidade ocorre tanto dentro da universidade quanto com o mundo lá fora. A comunicação é usada para fortalecer a visão da universidade sobre sustentabilidade, para desenvolver novas iniciativas, informar e obter feedback de todas as partes interessadas, por exemplo, pessoal, estudantes, profissionais e da sociedade em geral.

( ) Estágio 1 Orientado pela atividade. Os indivíduos e os grupos se esforçam para ampliar a atenção para a sustentabilidade. Os membros da equipe são informados sobre as iniciativas de sustentabilidade da universidade.

( ) Estágio 2 Orientado pelo processo. A sustentabilidade aparece regularmente nas pautas das reuniões, em publicações e apresentações da universidade.

( ) Estágio 3 Orientado pelo sistema. A comunicação sobre sustentabilidade se baseia em uma comunicação estruturada. A equipe e os gestores são bem informados sobre a opinião uns dos outros em relação a sustentabilidade.

( ) Estágio 4 Orientado pela cadeia. Os interessados diretos estão ativamente envolvidos na comunicação sobre sustentabilidade. Esta comunicação está em todos os sentidos, não apenas visando os interesses da própria universidade, mas também das partes interessadas. As publicações dos professores e estudantes sobre sustentabilidade aparecem regularmente em revistas científicas e meios públicos de comunicação.

( ) Estágio 5 Orientado pela sociedade. Uma grande variedade de atores da sociedade está envolvida na comunicação sobre sustentabilidade. Esta comunicação está em todos os sentidos, não apenas visando os interesses da própria organização, mas também da sociedade. Membros, equipe e estudantes estão realizando pesquisas sobre sustentabilidade.

Conhecimento

O conhecimento disponível sobre sustentabilidade é suficiente para permitir trabalhar ativamente na integração e na melhoria da sustentabilidade nas atividades da universidade. 
Além disso, uma rede externa funciona, a fim de utilizar esses conhecimentos disponíveis no mundo exterior.

( ) Estágio 1 Orientado pela atividade. O desenvolvimento de pessoal em sustentabilidade depende de iniciativas individuais. Os membros mantêm contato com os interessados diretos e com centros de especialização, a fim de ampliar seu conhecimento e experiência sobre sustentabilidade.

( ) Estágio 2 Orientado pelo processo. Há uma equipe responsável pelo plano de sustentabilidade. Este plano é principalmente de curto prazo. Para a execução do plano, as instalações são disponíveis pela gestão da universidade. Os benefícios sobre os conhecimentos em sustentabilidade estão presentes para as partes interessadas (stakeholders).

( ) Estágio 3 Orientado pelo sistema. Há um plano sistemático de desenvolvimento pessoal relacionado com a sustentabilidade a médio/longo prazo. $\mathrm{O}$ conhecimento dos interessados diretos (stakeholders) são usados sistematicamente para a realização deste plano. Para este objetivo, a rede externa (network) é mantida e expande de forma sistemática.

( ) Estágio 4 Orientado pelo cadeia. Os contatos regulares com a rede externa não só contribuem para o conhecimento dentro da universidade, mas também para a experiência dos parceiros da rede.

( ) Estágio 5 Orientado pela sociedade. A universidade tem um centro de conhecimento especializado relativo a sustentabilidade (inter) nacionalmente reconhecido. As características deste centro são: excelência, inovador, proativo. A sociedade se beneficia do processo de sustentabilidade a partir da experiência do centro de especialização.

Coerência

A universidade pode contribuir para a sustentabilidade em uma variedade de papéis: através da sua educação, da sua investigação, da sua própria operação e sua contribuição direta para a sociedade. Estes vários papéis podem reforçar-se mutuamente se houver cooperação entre eles. Por exemplo, o campus pode ser usado como uma ferramenta para a educação, a pesquisa ou interações sociais. Os estudantes podem contribuir para a investigação da sustentabilidade ou desenvolvimento da comunidade. A coerência entre os papéis permite que a instituição aja de acordo com seus próprios padrões (praticar o que prega).

( ) Estágio 1 Orientado pela atividade. As ações de concepção e implementação da sustentabilidade nos vários papéis da universidade ocorrem por meio de interação mútua.

( ) Estágio 2 Orientado pelo processo. Muitos exemplos podem ser dados das ações da universidade que estão explicitamente relacionadas com aspectos da sustentabilidade.

( ) Estágio 3 Orientado pelo sistema. As políticas e ações relacionadas com a sustentabilidade nos quatro papéis ocorrem de forma sistemática. Isto cria uma forte sinergia que inspira e evidentemente é benéfica para a sociedade e para os institutos que trabalham em todos os quatro papéis.

( ) Estágio 4 Orientado pela cadeia. A universidade funciona como uma entidade holística em que todos os departamentos, institutos e programas de estudo são partes orgânicas que interagem continuamente. As relações sinérgicas de políticas e ações não só existem entre os quatro papéis da universidade, mas também envolvem uma gama de stakeholders.

( ) Estágio 5 Orientado pela sociedade. A universidade tem uma política forte "portas abertas", e através da sociedade cria uma sinergia com vários atores envolvidos. Graças a isso, a universidade contribui de forma sistemática em relação aos aspectos de sustentabilidade com a sociedade. 
Transparência e prestação de contas

Os relatórios da universidade às suas partes interessadas sobre as suas atividades, prestação de contas e resultados relativos a sustentabilidade, são transparentes, inclusive para a sociedade como um todo.

( ) Estágio 1 Orientado pela atividade. Ocasionalmente, a gestão da universidade fornece informações sobre metas individuais, processos e resultados relacionados com a sustentabilidade. Isso ocorre apenas se é questionado. A informação é fornecida principalmente a um grupo limitado de funcionários.

( ) Estágio 2 Orientado pelo processo. Periodicamente, a gestão fornece informações estruturadas sobre os objetivos, processos e resultados relativos a sustentabilidade e Responsabilidade Social Corporativa (RSC). A informação é fornecida principalmente aos membros da instituição e alunos.

( ) Estágio 3 Orientado pelo sistema. A sustentabilidade e os relatórios de RSC são sistematicamente integrados ao relatório anual público. A comunicação é baseada nos interesses dos stakeholders. Os relatórios padrões são utilizados para expressar a transparência e a prestação de contas.

( ) Estágio 4 Orientado pela cadeia. A universidade oferece um feedback sistemático (relatórios) sobre a sustentabilidade e RSC para as partes interessadas. Desta forma, a universidade mantém-se responsável por toda a sua meta, ações e impactos. Esse feedback é usado sistematicamente para melhorar os objetivos, processos e resultados.

( ) Estágio 5 Orientado pela sociedade. A prestação de contas "está no cerne" da RSC e sustentabilidade na visão da universidade. A universidade reúne feedback sobre a sustentabilidade e RSC de uma ampla variedade de representantes da sociedade. Esse feedback é usado sistematicamente para melhorar os objetivos, processos e resultados. 